\title{
Scientific review of
}

\section{the impact of climate change on plant pests}
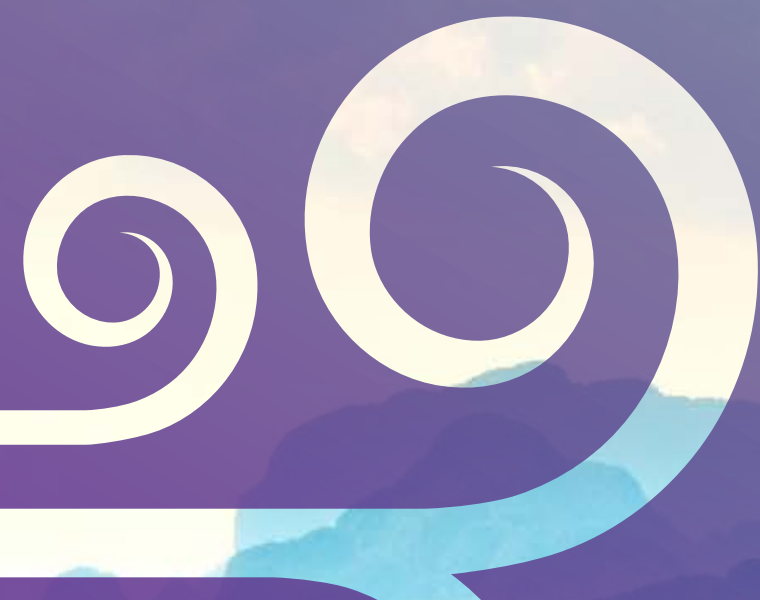

A global challenge to prevent and mitigate plant pest risks in agriculture, forestry and ecosystems
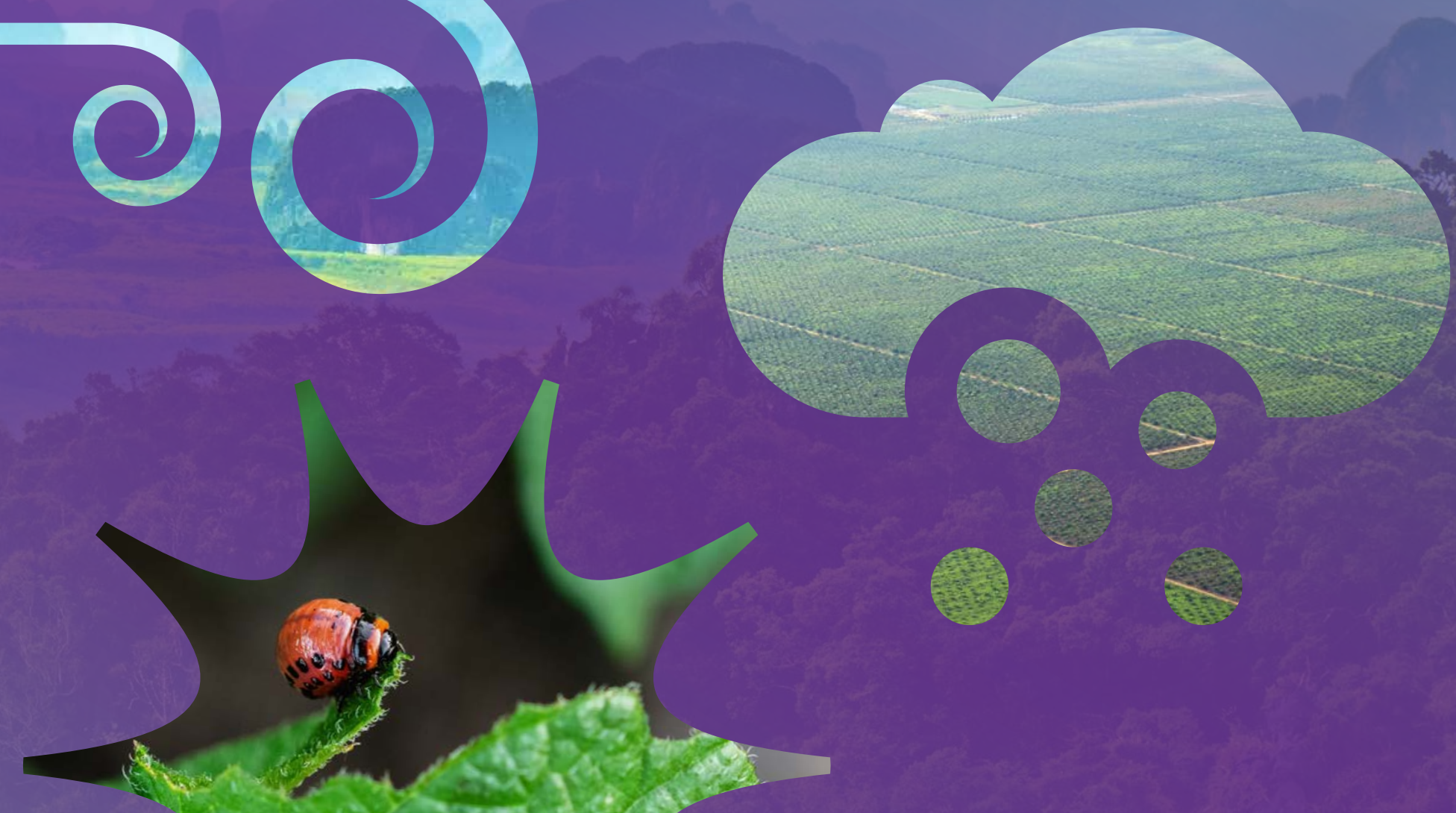

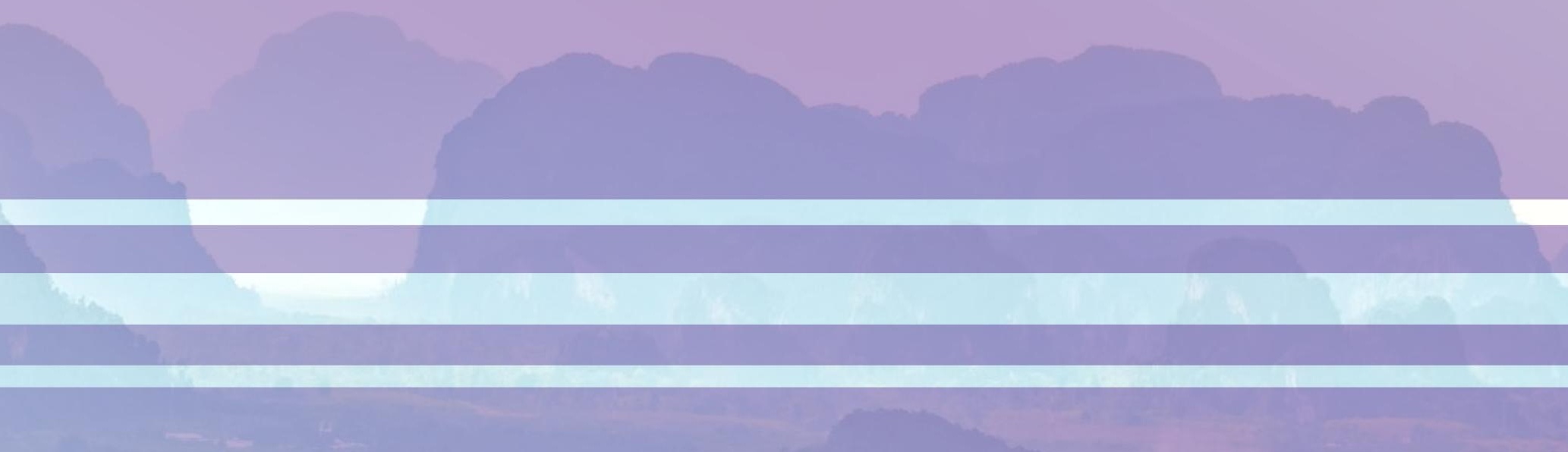

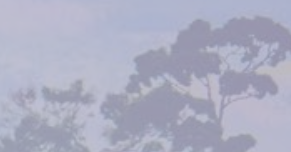

a.t.

$-2+3$ 


\section{Scientific review of the impact of climate change on plant pests}

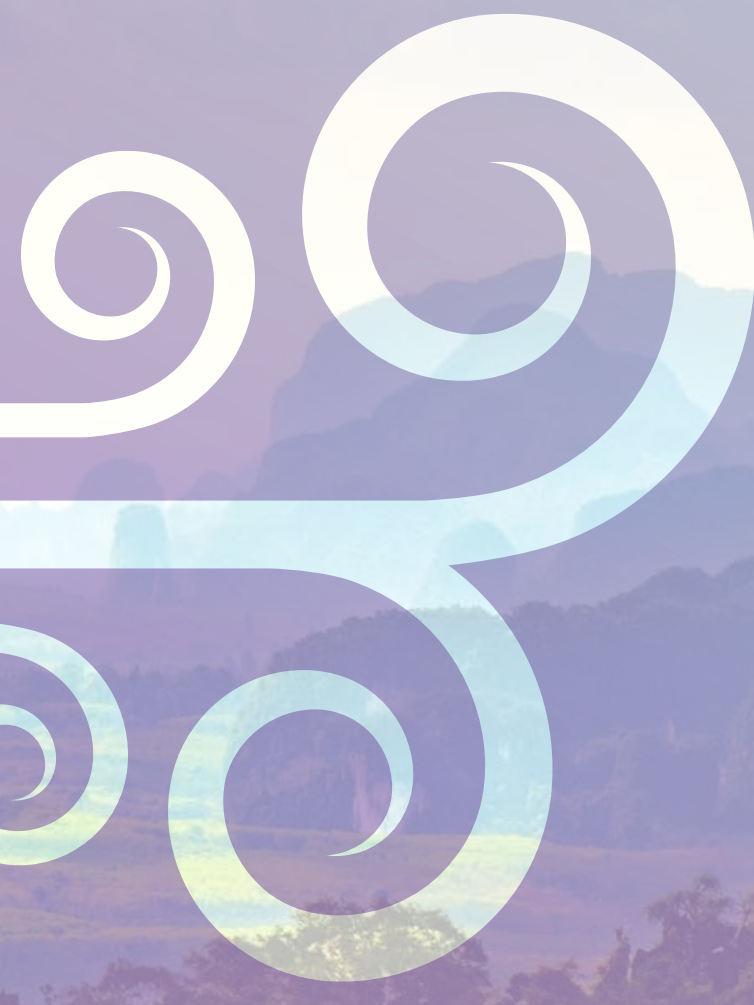

A global challenge to prevent and mitigate plant pest risks in agriculture, forestry and ecosystems

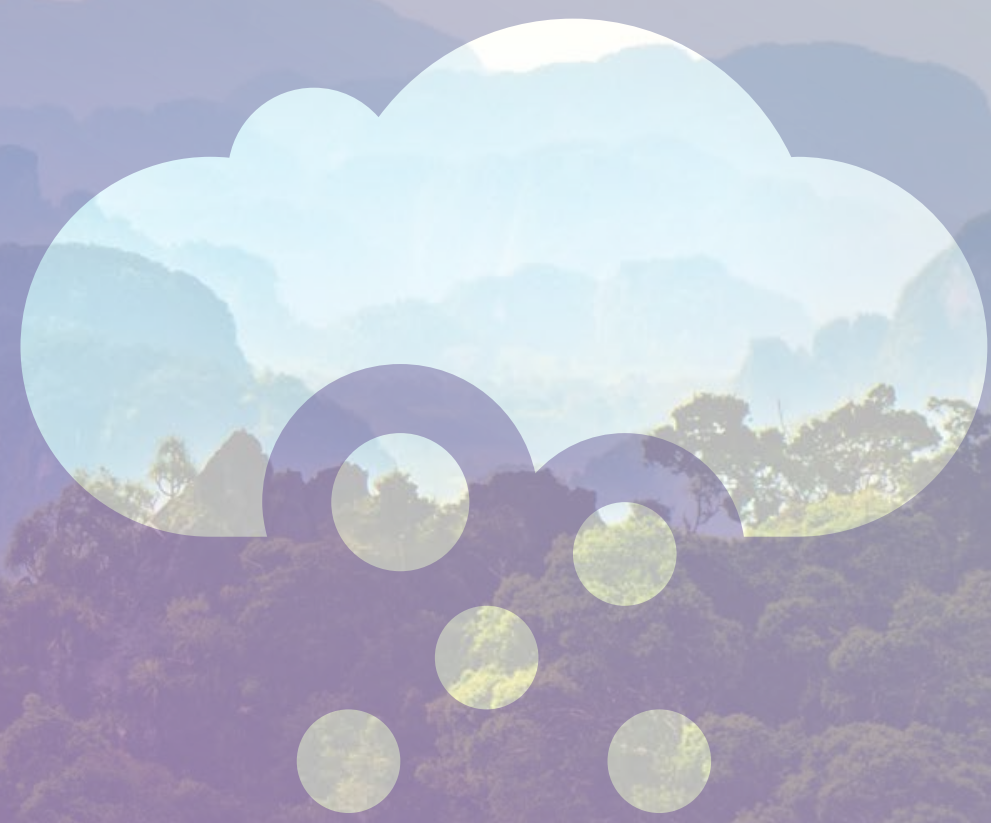

Drafting authors: Maria Lodovica Gullino (lead author, Italy), Ramon Albajes (Spain), Ibrahim Al-Jboory (Iraq), Francislene Angelotti (Brazil), Subrata Chakraborty (Australia), Karen A. Garrett (United States of America), Brett Phillip Hurley (South Africa), Peter Juroszek (Germany), Khaled Makkouk (Lebanon), Xubin Pan (China), Tannecia Stephenson (Jamaica). 


\section{Required citation:}

IPPC Secretariat. 2021. Scientific review of the impact of climate change on plant pests - A global challenge to prevent and mitigate plant pest risks in agriculture, forestry and ecosystems. Rome. FAO on behalf of the IPPC Secretariat.

https://doi.org/10.4060/cb4769en

The designations employed and the presentation of material in this information product do not imply the expression of any opinion whatsoever on the part of the Food and Agriculture Organization of the United Nations (FAO) concerning the legal or development status of any country, territory, city or area or of its authorities, or concerning the delimitation of its frontiers or boundaries. Dashed lines on maps represent approximate border lines for which there may not yet be full agreement. The mention of specific companies or products of manufacturers, whether or not these have been patented, does not imply that these have been endorsed or recommended by FAO in preference to others of a similar nature that are not mentioned.

The views expressed in this information product are those of the author(s) and do not necessarily reflect the views or policies of FAO.

Some rights reserved. This work is made available under the Creative Commons Attribution-NonCommercial-ShareAlike 3.0 IGO licence (CC BY-NC-SA 3.0 IGO; https://creativecommons.org/licenses/by-nc-sa/3.0/igo/legalcode)

Under the terms of this licence, this work may be copied, redistributed and adapted for non-commercial purposes, provided that the work is appropriately cited. In any use of this work, there should be no suggestion that FAO endorses any specific organization, products or services. The use of the FAO logo is not permitted. If the work is adapted, then it must be licensed under the same or equivalent Creative Commons licence. If a translation of this work is created, it must include the following disclaimer along with the required citation: "This translation was not created by the Food and Agriculture Organization of the United Nations (FAO). FAO is not responsible for the content or accuracy of this translation. The original English edition shall be the authoritative edition."

Third-party materials. Users wishing to reuse material from this work that is attributed to a third party, such as tables, figures or images, are responsible for determining whether permission is needed for that reuse and for obtaining permission from the copyright holder. The risk of claims resulting from infringement of any third-party-owned component in the work rests solely with the user.

Sales, rights and licensing. FAO information products are available on the FAO website (www.fao. org/publications) and can be purchased through publications-sales@fao.org. Requests for commercial use should be submitted via: www.fao.org/contact-us/licence-request. Queries regarding rights and licensing should be submitted to: copyright@fao.org.

Text in this document is not an official legal interpretation of the International Plant Protection Convention (IPPC) or its related documents, and is produced for public information only. To translate this material please contact ippc@fao.org for information about a co-publishing agreement. 


\section{Contents}

- Foreword $\quad$ v

- Acknowledgements vi

- Acronyms and abbreviations vii

- Executive summary ix

\begin{tabular}{|c|c|}
\hline Introduction & 1 \\
\hline Effects of climate change on agriculture, forestry and ecosystems & 2 \\
\hline Global pests affecting crops, forestry and ecosystems & 4 \\
\hline Pathways used by pests & 5 \\
\hline Approaches used to investigate the effects of climate change on plant pests & 10 \\
\hline Effects of climate change on plant pests & 20 \\
\hline Simulation of future pest risk & 21 \\
\hline Effects on pest species & 22 \\
\hline Case studies of individual pest species & 24 \\
\hline Prevention, mitigation and adaptation & 36 \\
\hline Preventive measures & 37 \\
\hline Recent technological developments & 41 \\
\hline Mitigation and adaptation & 43 \\
\hline Conclusions and recommendations & 45 \\
\hline Policy making and regulatory issues & 46 \\
\hline Research required & 47 \\
\hline International cooperation & 49 \\
\hline Capacity building & 50 \\
\hline References & 52 \\
\hline
\end{tabular}





\section{Foreword}

$\sum_{4 \infty \infty}^{+\infty} a$

8 limate change represents an unprecedented challenge to the world's bio-

8 sphere and to the global community. It is a threat beyond compare to the planet's biodiversity, to human health and to the world's economy. It also represents a unique challenge for plant health. Climate change will affect ecosystems and agricultural production systems throughout the world. It will influence international trade flows of agricultural products and it will change the infectivity, severity and distribution of pests throughout the world. Climate change will, in particular, present an extraordinary trial to the international plant health community and its ability to react in a scientific, decisive and unified manner to these challenges.

The International Year of Plant Health (IYPH) 2020 has been an effort to raise public and political awareness of plant health, and to help governments and the international community address plant health challenges. One important challenge to plant health that must be addressed is the impact of climate change. To this end, the IYPH International Steering Committee commissioned a scientific review of the topic. To strengthen the review's scientific foundation, the Steering Committee convened a panel of reputable scientists from around the world to write the review, and established a rigorous peer review system to validate its findings. This report details the outcome of the review and has been prepared by lead author Professor Maria Lodovica Gullino (University of Turin, Italy) and a group of ten co-authors representing all FAO regions and with expertise in plant pathology, entomology, herbology, climatology and data analytics. The scientific review was prepared under the auspices of the Secretariat of the International Plant Protection Convention (IPPC).

With this scientific review of the impact of climate change on pests and consequently plant health, the IYPH International Steering Committee hopes to provide the scientific background necessary to inform successful discussions on the assessment and management of climate change impacts in international phytosanitary fora. It is the hope of the IYPH International Steering Committee that the review will be an impetus for the Commission on Phytosanitary Measures of the IPPC to discuss and develop international policies to mitigate climate change impacts on plant health. This scientific review is considered a first step in implementing the IPPC Strategic Framework 2020-2030 Development Agenda item "Assessment and management of climate change impacts on plant health". It is our sincere hope and expectation that the review will elicit a decisive and unified response by the international community to the challenges posed to plant health by climate change.

Yours sincerely,

\section{Ralf Lopian}

Chairperson of the International Steering Committee for the IYPH 2020 


\section{Acknowledgements}

Maria Lodovica Gullino acknowledges the projects "Plant and Food Biosecurity" (PLANTFOODSEC, grant no. 261752), "Effective Management of Pests and Harmful Alien Species - Integrated Solutions" (EMPHASIS, grant no. 634179) and "EU-CHINA Lever for IPM Demonstration" (EUCLID, grant no. 633999); Ramon Albajes also acknowledges EMPHASIS and EUCLID, all funded by the European Commission. Peter Juroszek acknowledges the project "Potential Medium- and Long-Term Effects of the Projected Climate Change on Plant Diseases and on Fungicide Efficacy in Field Crops in Germany" (SIMKLIMA, granted to Benno Kleinhenz, grant no. FKZ 281B202616), supported by funds from the Federal Ministry of Food and Agriculture (BMEL) based on a decision of the Parliament of the Federal Republic of Germany via the Federal Office for Agriculture and Food (BLE) under the innovation support programme. Xubin Pan acknowledges the support from the Consulting Project of the Chinese Academy of Engineering (2019-ZD-4).

The precious and skilled technical support of Stefania Antro (Agroinnova, University of Torino) is kindly acknowledged. The authors also wish to thank the continuous support and help received from Viivi Kuvaja (IPPC Secretariat, FAO) and the helpful suggestions of the reviewers during the process.

This report was prepared with the contribution of selected experts in the FAO Plant Production and Protection Division, the Forestry Division, the Land and Water Division, and the Office of Climate Change, Biodiversity and Environment. 


\section{Acronyms and abbreviations}

- CGIAR Consultative Group on International Agricultural Research

- CLIMEX Climate modelling of extreme events

- COVID-19 Coronavirus disease 2019

- DNA Deoxyribonucleic acid

- FACE Free air $\mathrm{CO}_{2}$ enrichment

- FAO Food and Agriculture Organization of the United Nations

- IPCC Intergovernmental Panel on Climate Change

- IPPC International Plant Protection Convention

- ISPM International Standard for Phytosanitary Measures

- IYPH International Year of Plant Health

- NPPO National plant protection organization

$\rightarrow$ PRA Pest risk analysis

- TR4 Tropical race 4 (of Fusarium oxysporum)

$\Delta \mathrm{C}_{3} \quad$ Three-carbon compound produced by photosynthesis

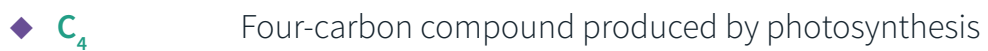

$-\mathrm{CO}_{2} \quad$ Carbon dioxide

$\bullet \mathrm{CH}_{4} \quad$ Methane

$-\mathrm{N}_{2} \mathrm{O} \quad$ Nitrous oxide 



\section{Executive summary}

$\sum_{4 \infty \infty}^{+\infty} 0$ limate change continues to present challenges to life and livelihoods \&globally and amplifies the problems humankind is already facing. The focus of this report is to outline the potential effects of climate change on plant pests, and hence on plant health, based on an analysis of scientific literature and studies that have investigated such aspects. A plant pest, hereafter referred to as a "pest", is any species, strain or biotype of plant, animal or pathogenic agent injurious to plants or plant products. Historic and current examples clearly show the extensive damage that can be caused by pest outbreaks. Warming facilitates the introduction of unwanted organisms; a single, unusually warm winter may be sufficient to assist the establishment of invasive pests, which otherwise would not be able to establish. In fact, the increased market globalization of recent years, coupled with increased temperatures, has led to a situation that is extremely favourable to pest movement and establishment, with concomitant increases in the risk of severe forest and crop impacts.

Studies have evaluated the effects of several atmospheric and climatic factors, including increased temperature, carbon dioxide and ozone and changing water or humidity patterns, on the distribution, occurrence and abundance of pests and the severity of the pest risk they pose. Most of the research has focused on managed systems (e.g. agricultural and horticultural crops, forest trees), whereas unmanaged systems have been more or less neglected. Many different research approaches have been used, ranging from conducting laboratory and field experiments to performing simulation studies of future pest risk.

Most studies, carried out with cereal and horticultural crops, indicate that, in general, pest risk from insects, pathogens and weeds will increase in agricultural ecosystems under climate-change scenarios, especially in today's cooler Arctic, boreal, temperate and subtropical regions. This is also mostly true for pathogens and insect pests in forestry. For unmanaged systems, there are only a few research results available and hence no general conclusions can be drawn.

Preventive, mitigation and adaptation measures to limit the international spread of pests through trade and travel is necessary. These range from measures such as use of healthy seed and planting material to the adoption of recent technological developments such as innovative methods of pesticide delivery. Short-and mid-term mitigation and adaptation options include measures such as use of resistant varieties and the alteration of microclimate.

Despite the wealth of studies on climate-change biology, there are still prominent gaps in research into the impact of climate change on pests and on hence on plant health. These gaps include the effect of climate change on the effectiveness of management strategies, on below-ground pests, and on forestry and unmanaged systems. A long-term, multidisciplinary approach is needed that addresses the issues of developing as well as industrialized countries. International cooperation needs to be enhanced and investment should also be directed to capacity building, to ensure strong systems for pest risk analysis, surveillance and monitoring. 
To conclude, the evidence reviewed in this report strongly indicates that in many cases climate change will result in increasing problems related to plant health in managed (e.g. agriculture, horticulture, forestry), semi-managed (e.g. national parks) and presumably also unmanaged ecosystems. Adjustments in plant-protection protocols are already necessary because of recent climatic changes, but further adjustments will become increasingly crucial in the future, assuming the projected climate-change scenarios come true. Maintaining managed and unmanaged ecosystem services and produce, including food, under climate-change conditions is of paramount importance. Preventive and curative plant protection is one of the key components needed to maintain and preserve current and future food security.

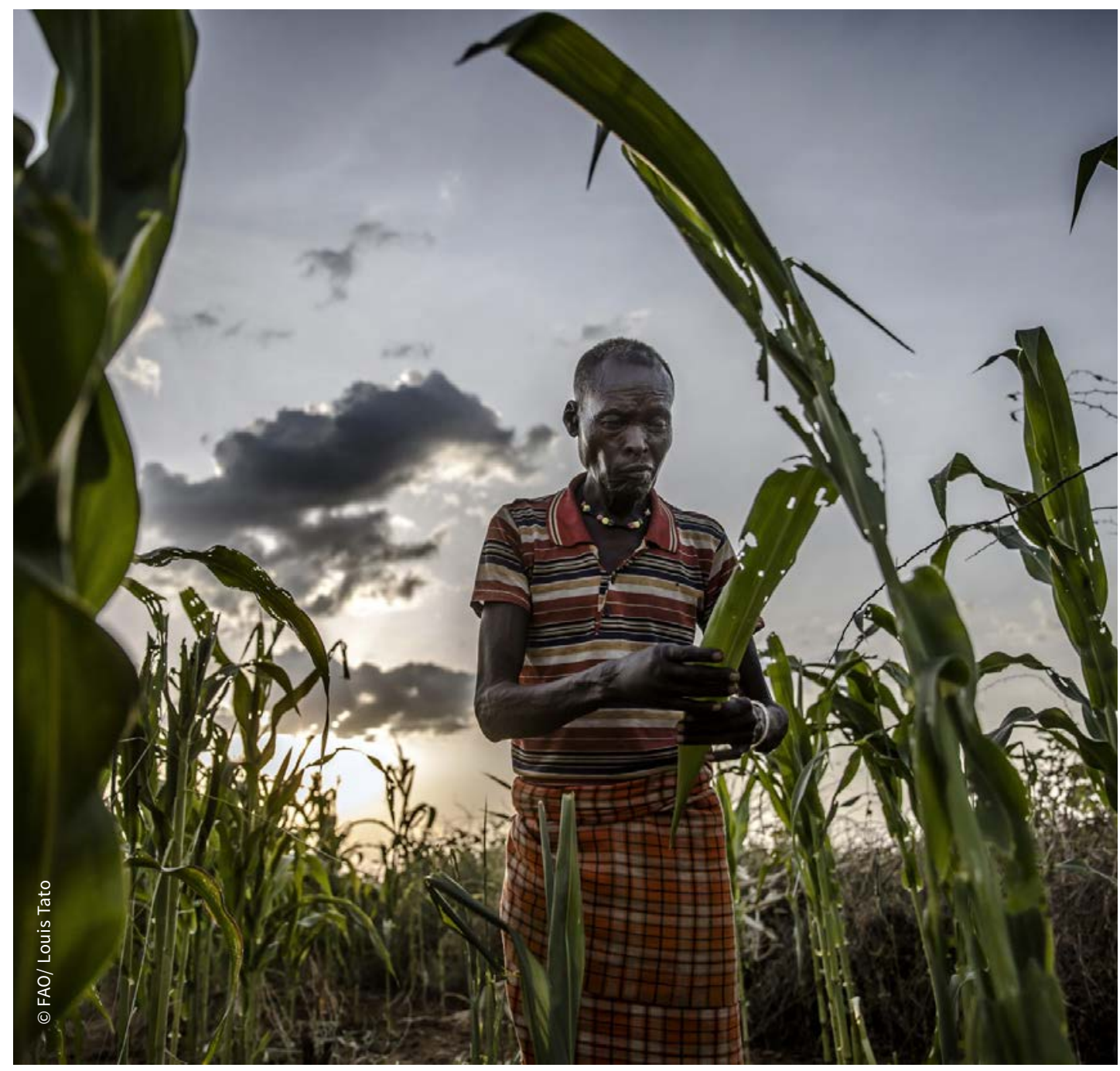




\section{Introduction}

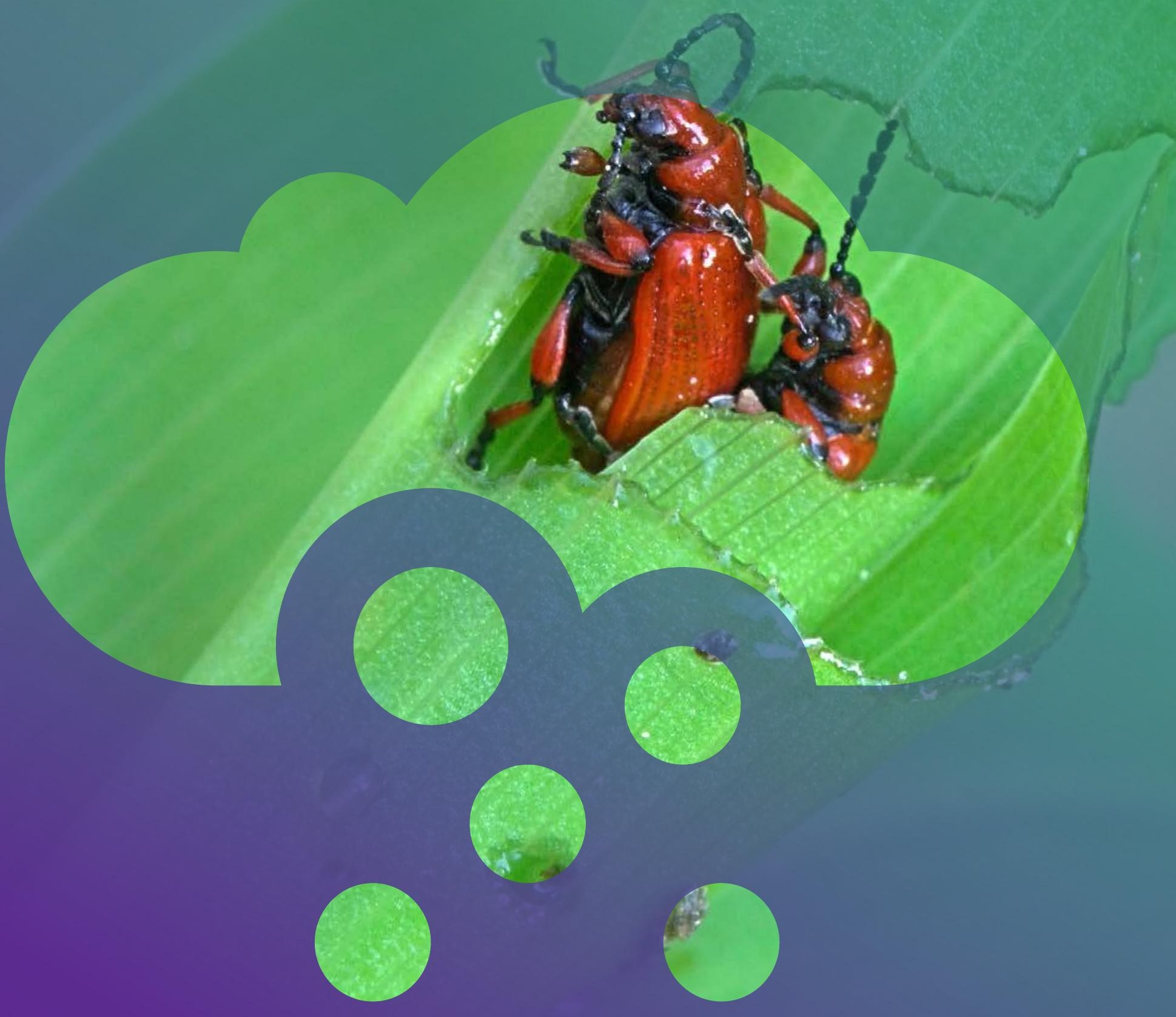




\section{Effects of climate change on agriculture, forestry and ecosystems}

The focus of this review is to assess the potential effects of climate change on plant pests and hence on plant health. A plant pest, hereafter referred to as a "pest", is any species, strain or biotype of plant, animal or pathogenic agent injurious to plants or plant products, as per the definition in the International Standard for Phytosanitary Measures No. 5 (ISPM 5) adopted by the Commission on Phytosanitary Measures of the International Plant Protection Convention (IPPC).

Climate change is defined as an increase in combined surface-air and sea-surface temperatures, averaged over the globe, over a 30-year period. Warming is expressed relative to the period 1850-1900, which is used as an approximation of pre-industrial temperatures. Warming from pre-industrial levels compared to the decade $2006-$ 2015 has been assessed to be $0.87^{\circ} \mathrm{C}$. Since 2000 , the estimated level of human-induced warming has been equal to the level of observed warming, with a likely range of \pm 20 percent accounting for uncertainty due to contributions from solar and volcanic activity over the historical period (IPCC, 2018). Climate models project robust differences in regional climate characteristics between the present day and global warming of $1.5^{\circ} \mathrm{C}$ and between 1.5 and $2.0^{\circ} \mathrm{C}$. Such differences include increases in mean temperature in most land and ocean regions, hot extremes in most inhabited areas, heavy precipitation in several regions, and the probability of drought and precipitation deficits in some regions (IPCC, 2018).

Climate change continues to present challenges to life and livelihoods globally (Altizer etal., 2013; IPCC, 2018). Changes observed include increased global land and ocean temperatures (Figure 1), loss of ice sheets and snow cover, rising sea levels, increased ocean acidification, more frequent warm extremes, more variable rainfall patterns and more frequent heavy-precipitation events and droughts (Figure 2). These changes have been attributed to increased emissions of anthropogenic greenhouse gases since the pre-industrial era, due to intensification of agricultural and industrial activities, combustion of fossil fuels, and changes in land use (Figures 3 and 4). Chemical analysis of ice and sediments indicates that atmospheric concentrations of carbon dioxide $\left(\mathrm{CO}_{2}\right)$, methane $\left(\mathrm{CH}_{4}\right)$ and nitrous oxide $\left(\mathrm{N}_{2} \mathrm{O}\right)$ have been at unprecedented levels for at least the last 800000 years.

Their effects, together with those of other anthropogenic drivers such as deforestation, are the dominant cause of the observed warming since the mid-twentieth century (IPCC, 2014a, 2014b, 2018; Wuebbles and Hayhoe, 2002). Importantly, global climate change, especially global warming, is likely to continue. According to the Intergovernmental Panel on Climate Change (IPCC) Special Report on Global Warming of $1.5^{\circ} \mathrm{C}$, global warming is likely to reach a $1.5^{\circ} \mathrm{C}$ increase between 2030 and 2052 compared to pre-industrial levels if the warming continues to increase at the current pace (IPCC, 2018). ${ }^{1}$

\footnotetext{
แัเ

1 The goal of the Paris Agreement (2015) is to limit global warming to well below $2{ }^{\circ} \mathrm{C}$, preferably to $1.5^{\circ} \mathrm{C}$, compared to pre-industrial levels.
} 
Climate-related risks are higher for global warming of $1.5^{\circ} \mathrm{C}$ compared to the current risks, ${ }^{2}$ but the risks are significantly more severe if the global warming reaches $2^{\circ} \mathrm{C}$. Risks depend on the degree and pace of warming, geographical location, levels of regional and local development and vulnerability, and realized adaptation and mitigation activities (IPCC, 2018).

Climate-change impacts are already emerging for natural and human systems, including changes in water quantity and quality, and shifts in geographical ranges, seasonal activities, migration patterns, species abundance and interactions for many terrestrial, freshwater and marine species (IPCC, 2014a, 2019a, 2019b), with more negative than positive impacts on the yields of most crops (Porter etal., 2019). There is evidence that climate change is affecting biological systems at multiple scales, from genes to ecosystems (Garrett etal., 2006; Sutherst etal., 2011). According to Scheffers etal. (2016), anthropogenic climate change has impaired 82 percent of 94 core ecological processes recognized by biologists, from genetic diversity to ecosystem function.

Furthermore, already existing risks such as reduced freshwater availability will be amplified, and new ones will arise during and beyond the twenty-first century. Future impacts will include increased extinction risk. For example, most plant species cannot naturally change their geographical range quickly enough to keep pace with the rate of climate change, and marine organisms will be exposed to lower oxygen levels and greater acidification, to which they might not be able to adapt. Further climate change may also threaten food security through impacts on food crops and plantbased animal feed. For wheat, rice and maize, the worst impacts are expected in the tropics and subtropics, with climate change projected to negatively impact production where local temperature increases by ${ }^{\circ} \mathrm{C}$ or more above late twentieth-century levels, although some individual locations may benefit from this change, especially at higher latitudes and altitudes. Global food and fibre production, plant protection and plant biosecurity, which include all strategies to assess and manage the risks posed by infectious diseases, quarantine regulated pests, invasive alien species and living modified organisms in natural and managed ecosystems, will also be adversely impacted (Gregory etal., 2009; Stack, Fletcher and Gullino, 2013).

The aim of this report is to provide information on (i) what has happened in the last decades; (ii) what is expected to happen in the coming decades as a result of climate change; and (iii) what we can do in order to mitigate the impacts of, and adapt to, changing climates locally, regionally and globally.

It is beyond the scope of this report either to address the causes of climate change or to provide a comprehensive summary of all results published during the past 30 years. Instead, many examples of publications are cited for further, in-depth reading.

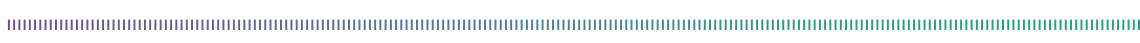

2 According to the IPCC Special Report on Global Warming of $1.5^{\circ} \mathrm{C}$ (IPCC, 2018), human activities have already caused approximately $1.0^{\circ} \mathrm{C}$ of global warming above pre-industrial levels. 
Figure 1

RCP 2.6

RCP 8.5

(a) Change in average surface temperature (1986-2005 to 2081-2100)

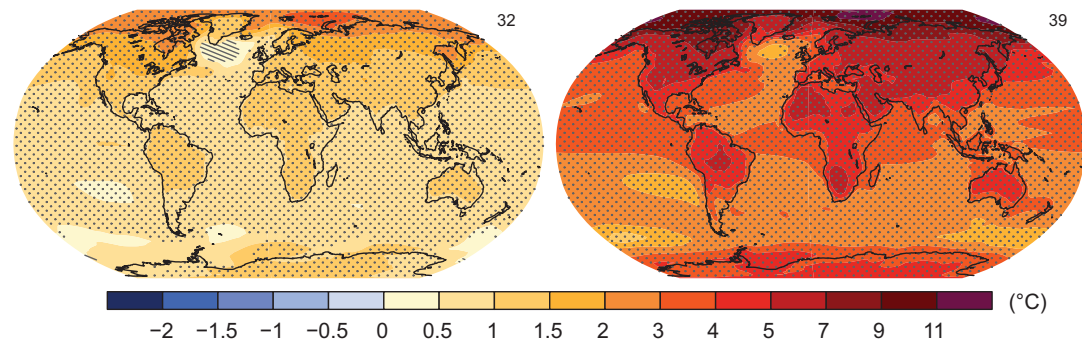

(b)

Change in average precipitation (1986-2005 to 2081-2100)

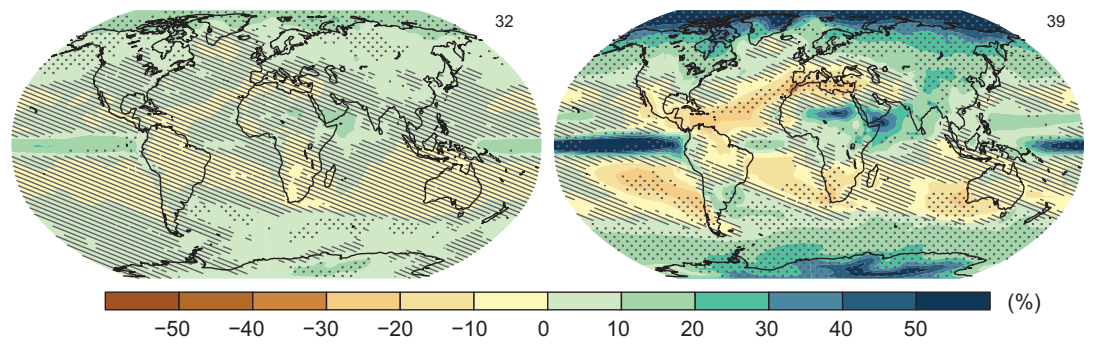

(c) Northern Hemisphere September sea ice extent (average 2081-2100)

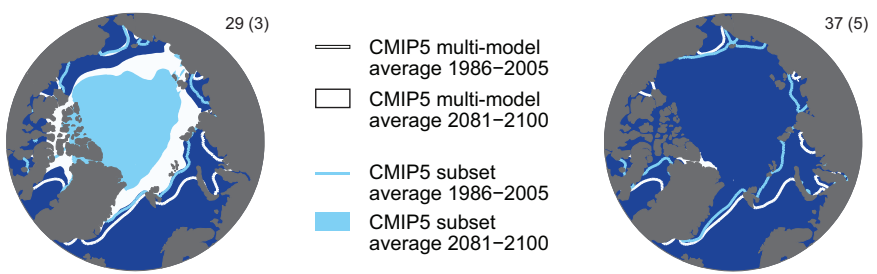

(d) Change in ocean surface $\mathrm{pH}(1986-2005$ to 2081-2100)

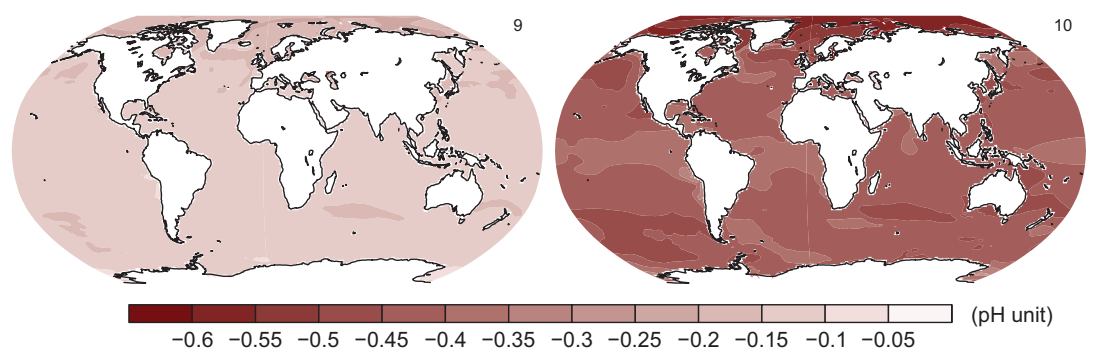

Source: IPCC (2013).

The original, full legend for Figure 1 as published in IPCC (2013) is as follows:

Figure SPM. 8 | Maps of CMIP5 multi-model mean results for the scenarios $R C P 2.6$ and RCP8.5 in 2081-2100 of (a) annual mean surface temperature change, (b) average percent change in annual mean precipitation, (c) Northern Hemisphere September sea ice extent, and (d) change in ocean surface $\mathrm{pH}$. Changes in panels (a), (b) and (d) are shown relative to 1986-2005. The number of CMIP5 models used to calculate the multi-model mean is indicated in the upper right corner of each panel. For panels (a) and (b), hatching indicates regions where the multi-model mean is small compared to natural internal variability (i.e., less than one standard deviation of natural internal variability in 20-year means). Stippling indicates regions where the multi-model mean is large compared to natural internal variability (i.e., greater than two standard deviations of natural internal variability in 20-year means) and where at least $90 \%$ of models agree on the sign of change (see Box 12.1). In panel (c), the lines are the modelled means for 1986-2005; the filled areas are for the end of the century. The CMIP5 multi-model mean is given in white colour, the projected mean sea ice extent of a subset of models (number of models given in brackets) that most closely reproduce the climatological mean state and 1979 to 2012 trend of the Arctic sea ice extent is given in light blue colour. For further technical details see the Technical Summary Supplementary Material. \{Figures 6.28, 12.11, 12.22, and 12.29; Figures TS.15, TS.16, TS.17, and TS.20\}
For more information, please consult the original source (IPCC, 2013). Reproduced with the kind permission of the Intergovernmental Panel on Climate Change. 
Observed change in annual precipitation over land

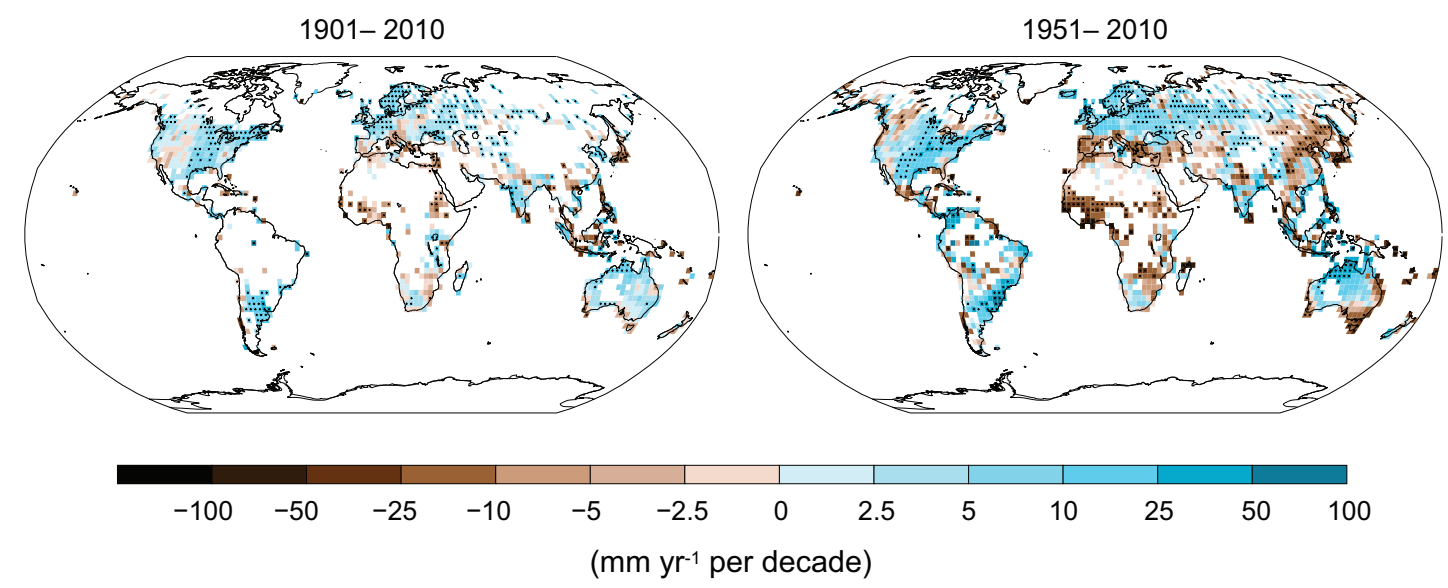

Source: IPCC (2013).

The original full legend for Figure 2 as published in IPCC (2013) is as follows:

Figure SPM.2 | Maps of observed precipitation change from 1901 to 2010 and from 1951 to 2010 (trends in annual accumulation calculated using the same criteria as in Figure SPM.1) from one data set. For further technical details see the Technical Summary Supplementary Material. \{TS TFE.1, Figure 2; Figure 2.29\}

For more information, please consult the original source (IPCC, 2013). Reproduced with the kind permission of the Intergovernmental Panel on Climate Change. 


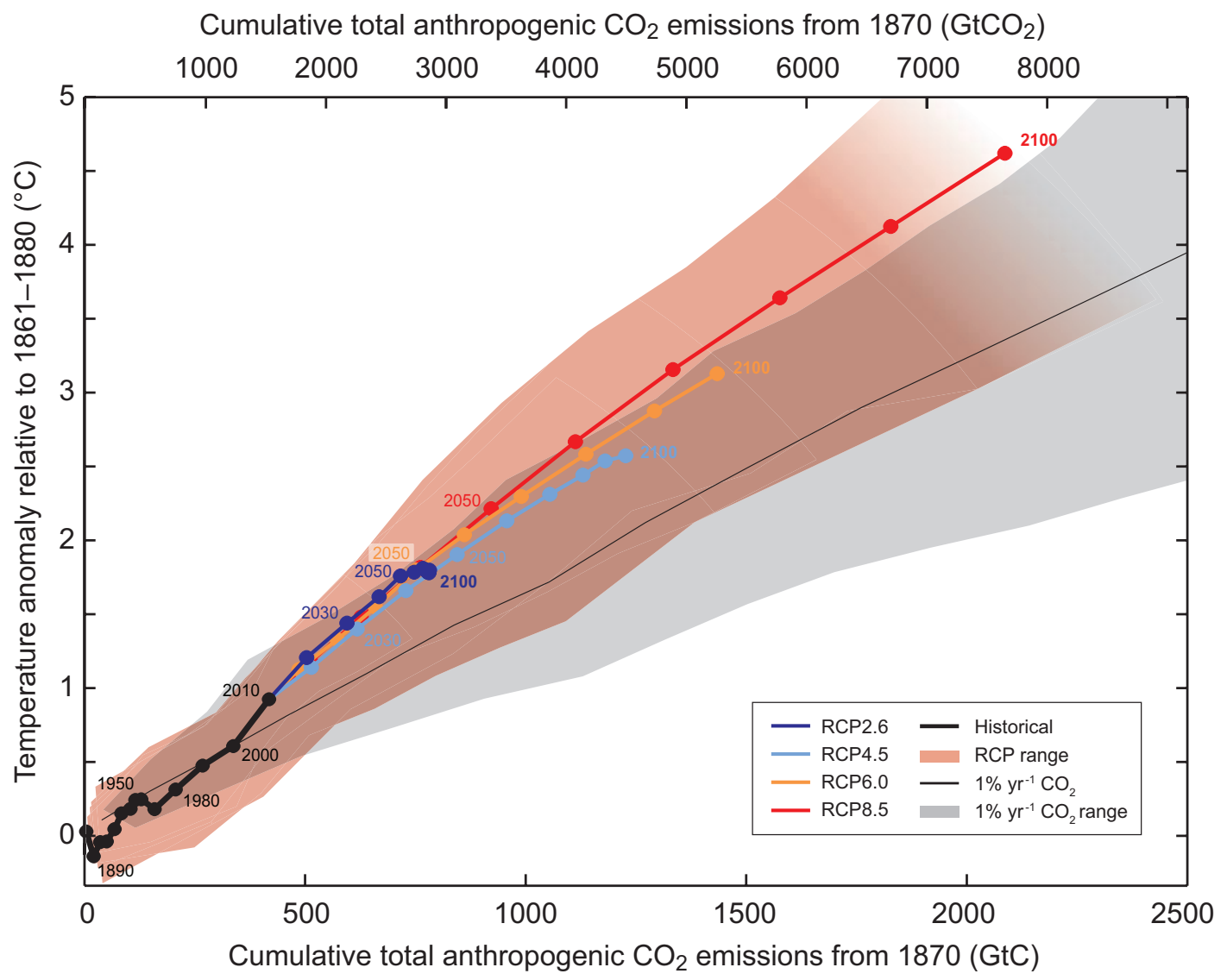

Source: IPCC (2013).

The original full legend for Figure 3 as published in IPCC (2013) is as follows:

Figure SPM.10 | Global mean surface temperature increase as a function of cumulative total global $\mathrm{CO}_{2}$ emissions from various lines of evidence. Multimodel results from a hierarchy of climate-carbon cycle models for each RCP until 2100 are shown with coloured lines and decadal means (dots). Some decadal means are labeled for clarity (e.g., 2050 indicating the decade 2040-2049). Model results over the historical period (1860 to 2010) are indicated in black. The coloured plume illustrates the multi-model spread over the four RCP scenarios and fades with the decreasing number of available models in RCP8.5. The multi-model mean and range simulated by CMIP5 models, forced by a $\mathrm{CO}_{2}$ increase of $1 \%$ per year $\left(1 \% \mathrm{yr}-1 \mathrm{CO}_{2}\right.$ simulations), is given by the thin black line and grey area. For a specific amount of cumulative $\mathrm{CO}_{2}$ emissions, the $1 \%$ per year $\mathrm{CO}_{2}$ simulations exhibit lower warming than those driven by $R C P s$, which include additional non- $\mathrm{CO}_{2}$ forcings. Temperature values are given relative to the 1861-1880 base period, emissions relative to 1870. Decadal averages are connected by straight lines. For further technical details see the Technical Summary Supplementary Material. \{Figure 12.45; TS TFE.8, Figure 1\}
For more information, please consult the original source (IPCC, 2013). Reproduced with the kind permission of the Intergovernmental Panel on Climate Change. 


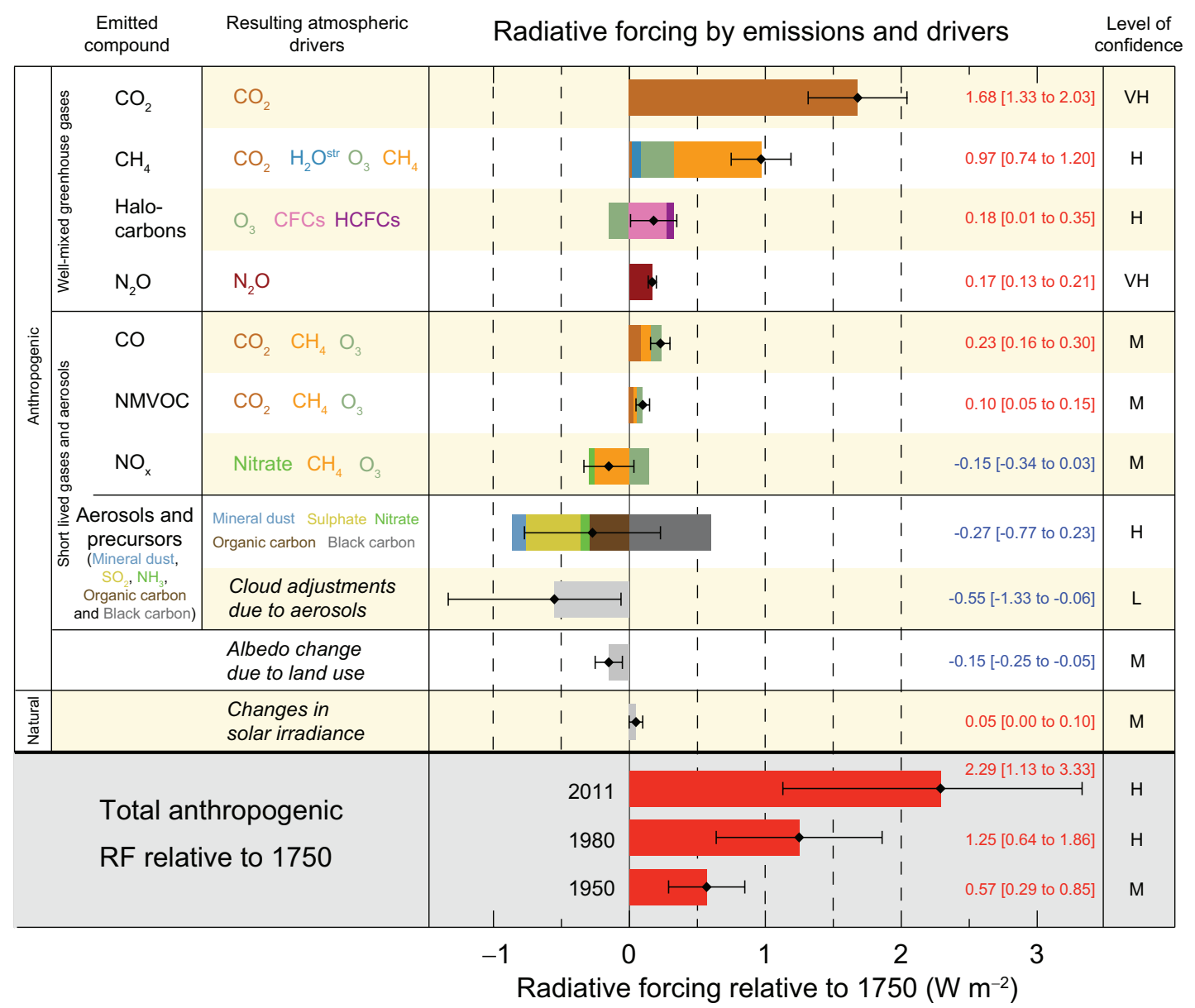

Source: IPCC (2013).

The original, full legend for Figure 4 as published in IPCC (2013) is as follows:

Figure SPM.5 | Radiative forcing estimates in 2011 relative to 1750 and aggregated uncertainties for the main drivers of climate change. Values are global average radiative forcing (RF14), partitioned according to the emitted compounds or processes that result in a combination of drivers. The best estimates of the net radiative forcing are shown as black diamonds with corresponding uncertainty intervals; the numerical values are provided on the right of the figure, together with the confidence level in the net forcing $\mathrm{VH}$ - very high, $H$ - high, $M$ - medium, $L$ - low, VL - very low). Albedo forcing due to black carbon on snow and ice is included in the black carbon aerosol bar. Small forcings due to contrails $\left(0.05 \mathrm{~W} \mathrm{~m}^{-2}\right.$, including contrail induced cirrus), and HFCs, PFCs and SF (total $0.03 \mathrm{~W} \mathrm{~m}^{-2}$ ) are not shown. Concentration-based RFs for gases can be obtained by summing the like-coloured bars. Volcanic forcing is not included as its episodic nature makes is difficult to compare to other forcing mechanisms. Total anthropogenic radiative forcing is provided for three different years relative to 1750 . For further technical details, including uncertainty ranges associated with individual components and processes, see the Technical Summary Supplementary Material. \{8.5; Figures 8.14-8.18; Figures TS.6 and TS.7\}
For more information, please consult the original source (IPCC, 2013). Reproduced with the kind permission of the Intergovernmental Panel on Climate Change. 


\section{Global pests affecting crops, forestry and ecosystems}

Since their domestication, around 10000 years ago, crops have been threatened by a multitude of pests causing yield losses often leading to starvation and social unrest. On average, at a global scale, between 10 and 28 percent of crop production is lost to pests (Savary etal., 2019). Further post-harvest losses are observed, with the worst scenarios in developing countries. Moreover, besides losses, the presence of mycotoxins (toxins produced by fungi) in food and feed can severely threaten the health of humans and livestock (Magan, Medina and Aldred, 2011; Van Der FelsKlerx, Liu and Battilani, 2016).

Historic and current examples clearly show the extensive damage that can be caused by pest outbreaks.

Among insect pests, two classical examples show the economic and social damage resulting from invasive expansion. One is the invasion and destruction of European vineyards by the insect phylloxera (Daktulosphaira vitifoliae) during the second half of the nineteenth century, and the second is the Colorado potato beetle (Leptinotarsa decemlineata) in the twentieth century, which rapidly colonized potato plots. Both of these pests originated in the United States of America. More recently, several native insect species from North America, with no prior records of severe infestation, have emerged as devastating pests of forest resources because of changes in their population dynamics. These include the aspen leaf miner (Phyllocnistis populiella), the leafblotch miner (Micrurapteryx salicifoliella) and Janet's looper (Nepytia janetae), which have decimated millions of hectares of aspen, willows, and sprucefir forests since the early 1990s (Bebber, Ramotowski and Gurr, 2013). Other native species that have become pests include the mountain and southern pine beetles (Dendroctonus ponderosae and Dendroctonus frontalis, respectively) and the spruce beetle (Dendroctonus rufipennis), which have recently expanded their distribution, infesting commercially important pine and spruce trees (Anderegg, Kane and Anderegg, 2013; Bebber, Ramotowski and Gurr, 2013).

Classical examples of the damage caused by crop and forest diseases include the Irish potato famine caused by Phytophthora infestans in the 1840s, the devastating impact of coffee rust in Ceylon caused by Hemileia vastatrix in the 1860s, and the Great Bengal Famine in 1943 caused by Helminthosporium oryzae (Schumann, 1991). Another major example not to be forgotten is the chestnut blight caused by Cryphonectria parasitica, which wiped out the American chestnut tree (Castanea dentata): by the 1950s, 80 percent of the chestnut trees had died (Schumann, 1991), severely affecting the landscape of an entire country. The threat persists. New and more virulent strains of the rust fungi Puccinia graminis (Saunders, Pretorius and Hovmøller, 2019) and Puccinia striiformis are currently spreading (Liu etal., 2017) and a new invasive lineage of Phytophthora infestans has rapidly displaced other late-blight genotypes (Cooke etal., 2012). The sudden wilt of olive trees caused by Xylella fastidiosa subsp. pauca, which has destroyed millions of olive trees in Apulia (Italy) and also threatens other European and Mediterranean countries, is an example of how a pathogen can affect a crop as well as the landscape of a region (Schneider etal., 2020; Sicard etal., 2018). In California and Oregon in the United States of America, as well as in other areas, Phytophthora ramorum, which causes sudden oak 
death, represents a threat to forest ecosystems (Rizzo, Garbelotto and Hansen, 2005), while other species of Phytophthora, such as P. kernoviae and P. agathidicida, are affecting the iconic and culturally important kauri in New Zealand (Scott and Williams, 2014) and P. pinifolia is damaging pine forests in Chile (Duran etal., 2008).

In addition to insects and plant pathogens, extensive damage to plants can also be caused by nematodes. According to Williamson and Gleason (2003), nematodes are among the most frequently occurring organisms on earth, affecting all ecosystems. Most of them are free-living and harmless to plants, for instance consuming microorganisms such as bacteria, but a small number of nematode species are obligate parasites of plants, and some of these plant-parasitic nematodes can pose a serious threat to managed and unmanaged ecosystems. In agriculture, the most economically important groups of nematodes are the sedentary endoparasites, including the genera Heterodera and Globodera (both cyst nematodes) and Meloidogyne (rootknot nematodes). In forestry, pine wilt disease, caused by the pine wilt nematode (Bursaphelenchus xylophilus), is one of the most devastating invasive diseases affecting pine trees (Pinus spp.), with significant impacts on natural ecosystems in Africa, North America, Asia, and Europe (CABI, 2021a). It is particularly devasting in eastern Asia, including China, Japan and the Republic of Korea (Ikegami and Jenkins, 2018).

Finally, some plant species are themselves pests. Weeds are "unwanted plants" in agriculture, horticulture, forestry and unmanaged ecosystems (Juroszek and von Tiedemann, 2013a; Korres etal., 2016; Wan and Wang, 2019). Thus, a weed is a plant prevalent in the wrong place or at the wrong time. Weeds have a range of properties that may be of benefit. Some weed species may provide useful ecosystem services, such as providing food for pollinators like bees, providing habitat for many beneficial organisms, and providing soil cover, thereby reducing soil erosion. They can also be primary colonizers following soil or ecosystem damage (e.g. fire, landslips), and in stabilizing riverbanks and sand dunes. In addition, some are traditional medicinal plants. However, weeds may cause contact dermatitis or incite allergies through their pollen, and they can be toxic to livestock (Ziska, Epstein and Schlesinger, 2009). They can also have a negative impact where they are not wanted. Many weeds have a wide environmental tolerance and a high level of phenotypic plasticity and evolutionary potential (Clements and DiTommaso, 2011), providing them with a very high competitive ability compared to crop plants, which have been selected to be homogenous. Weeds can therefore cause great losses in both the quality and quantity of crops and other plants and habitats, because they are competing for below-ground (e.g. water, nutrients) and above-ground (e.g. light) resources (Karkanis etal., 2018; Naidu, 2015; Peters, Breitsameter and Gerowitt, 2014; Ramesh etal., 2017). For example, the production of carrots (Daucus carota), even in a home garden, is impossible without weed control, due to the poor competitive ability of carrot seedlings.

\section{Pathways used by pests}

Pest dispersal occurs through both natural and anthropogenic processes, strongly facilitated during the past decades by the globalization of markets for plants and plant products including food, planting material and wood. Global travel and the trade of agricultural products have moved crops, weeds, pathogens, and insect pests away from their native environments to new ones. Newly introduced crops may expand pest distribution, and the introduction of new pests into a completely 
new ecosystem may cause extremely serious damage because pests and hosts may not have coevolved together. This coevolution has been especially recognized for plants and their pests (Woolhouse et al., 2002) and has created a stable balance between hosts and pests within their endemic ecosystems. As an example, pine wilt nematode (see case study below), which has coevolved with the host plant species in its native area, North America, does not cause serious damage there. Once introduced into Asia, however, it killed several millions of trees of various Pinus species.

According to Anderson etal. (2004), half of all emerging diseases of plants are spread by global travel and trade, while natural spread, assisted by weather events, is the second most important factor. In addition, there are also likely to be interactions between pest establishment and climatic or weather conditions. For example, global warming may facilitate the establishment of some pests that would otherwise not be able to establish (e.g. during an unusually warm winter under temperate climatic conditions). In fact, the increased market globalization of recent years, coupled with increased temperatures, has led to a situation that is extremely favourable to pest movement and establishment, with concomitant increases in the risk of severe yield losses (Deutsch etal., 2018; Savary etal., 2019). When considering the potential impact of climate change on plant health and hence on plant distribution, it is therefore important to understand not only which conditions allow pests to thrive, but also the pathways by which they move from one place to another.

An understanding of the pathways is also needed when determining what measures should be taken to mitigate and adapt to the changes in pest risk brought about by climate change. Considerable national and international efforts have been made to reduce the risk of international movement of pests (Meurisse etal., 2019), including the publication and implementation of International Standards for Phytosanitary Measures (ISPMs), developed under the auspices of the Commission on Phytosanitary Measures and the Secretariat of the IPPC. These include guidance on how to conduct pest risk analysis (PRA) to determine the risk of introduction (entry and establishment) and spread of pests and to select which measures to apply to prevent this occurring (ISPM 2, 2019; ISPM 11, 2019; ISPM 21, 2019). Such phytosanitary measures are generally applied with reference to pathway risks. As there is a requirement to periodically review the information supporting the PRA (ISPM 11, 2019), this presumably includes re-evaluation of the pathway risks, or at least those that are extremely dependent on changing climatic conditions such as the occurrence of extreme weather events that can spread quarantine pests across great distances.

A summary of the main types of pathways is provided below.

\section{Wood packaging}

Historically, wood, including packaging, has played a major role in spreading plant pests. Among the examples that show the significance of such a pathway is the movement of invasive insect species, such as the wood beetle Anoplophora glabripennis (Coleoptera: Cerambycidae), in packaging during international trade (EPPO, 2020a, 2021a). This species is polyphagous (i.e. it feeds on a wide range of foods), feeding on several species of the trees maple (Acer), poplar and aspen (Populus), willow (Salix) and elm (Ulmus) in forests and urban environments. Native to China and the Republic of Korea, it has been introduced into the United States of 
America and Canada in infested wood packaging and it has also been detected in several European countries. Eradication programmes are underway in these countries, these involving the detection, removal and destruction of infested trees. Careful inspection and treatment of solid wood packaging material, such as pallets and dunnage, is an international requirement to prevent new introductions. Modelling efforts to predict the geographical distribution of the beetle have shown that climate change may alter its distribution and impact (Hu etal., 2009).

Wood packaging has also been indicated as the likely pathway of many bark beetle species, such as Ips grandicollis (Coleoptera: Curculionidae), as well as other serious forest pests such as the emerald ash borer, Agrilus planipennis (Coleoptera: Buprestidae), and the Sirex woodwasp, Sirex noctilio (Hymenoptera: Siricidae) (Meurisse etal., 2019). Movement of the pine wilt nematode, B. xylophilus (see case study), or its insect vector, through untreated wood packaging material has also been observed (Sousa etal., 2011).

\section{Seeds, planting material, soil and growing media}

Globalization of seed and planting-material markets is one of the main causes of the recent and rapid spread of plant pathogens to new hosts. Moreover, some of the newly introduced pathogens and insect pests that are typical of warm areas are spreading easily in temperate regions, because of increases in temperature. In general, seeds are vectors of pests. Mature plants are also great vectors of live insects including mites, aphids, caterpillars, leaf miners and thrips. For this reason, Australia, for instance, has completed a PRA on cut flowers that lists the main insects associated with them.

Particularly in the vegetable sector, the recent spread of new pathogens in different countries is clearly linked to the fact that, being seed-borne, their diffusion is favoured by market globalization; the effect of global warming on plants and their hosts has also contributed to this spread. This has been shown to be the case, for instance, with Alternaria spp., Fusarium equiseti and Myrothecium spp., which have recently been observed on lettuce, wild and cultivated rocket, lamb's lettuce, basil and spinach (Gilardi, Garibaldi and Gullino, 2018). Tomato viruses (Tomato brown rugose fruit virus) and viroids (Potato spindle tuber viroid) are classic, recent and topical examples. Tomato brown rugose fruit virus has emerged in the last few years and has spread easily by seed movement. Many of the pathogens that cause severe losses in leafy vegetables, such as those mentioned above, can be seed-transmitted and hence go unnoticed. Thus, even low levels of seed infection can lead to the rapid emergence of new diseases in distant geographical areas (Gitaitis and Walcott, 2007; Gullino, Gilardi and Garibaldi, 2014a, 2019; Munkvold, 2009). Unfortunately, this happens very frequently, as shown by many recent introductions, despite the presence of industry and international standards defined in order to reduce this risk.

The ornamental industry, due to its international nature, is greatly affected by the introduction of pests through infected material (Daughtrey and Buitenhuis, 2020). Ornamental plants, whether started from seed, from cuttings or from cane section, can easily harbour pests. Only plants micropropagated through tissue culture (generally foliage plants) have a considerably reduced risk of infection by pathogens, provided that they are kept clean, consequently avoiding reinfection (Chen and Henny, 2006). Several of the most damaging insect and mite pests of greenhouse 
crops have originated through the importation of infested plant material and have established quickly because of the special environmental conditions of greenhouses (Albajes etal., 1999; Wang etal., 2015). Ornamental coffee plants imported from Costa Rica and infected by Xylella fastidiosa subsp. pauca are considered the possible vector of this destructive pathogen in Europe (Bergsma-Viami etal., 2015).

Soil and potting media, often imported, can harbour soil-borne pathogens (e.g. Fusarium spp., nematodes), the larvae of insect pests and weed seeds. This has been well documented in relation to peat and other media used in the ornamental industry and in nurseries. Contamination of growing substrates by soilborne pathogens (e.g. Fusarium oxysporum, Pythium spp., Rhizoctonia solani) results in incomplete disinfestation and in early attacks of young plants (Garibaldi and Gullino, 1995).

In addition to the pest risk posed by the movement of seed, planting material, soil and growing media described above, a new type of threat has emerged in recent years, with the increasing online market that spreads planting material around the world. The planting material marketed as such is often of low quality and generally not subject to phytosanitary control, and hence it represents a new type of threat. This aspect, not yet considered at the moment, should be taken into account in the future.

\section{Conveyances, cargo and movement of animals}

Tractors, cars, trucks, trains, ships, aeroplanes, containers, re-sold used agricultural equipment, and other vehicles are common means for passively moving pests. Indeed, plant pathologists, entomologists and weed scientists often consider the speed of spread of pests as directly related to the speed of conveyances.

Living organisms can also spread pests such as weed seeds located on animal skin or fur. For example, movement of animal herds by pastoral communities into new territories in search of pasture has spread seeds of the invasive alien plant Parthenium hysterophorus in eastern and southern Africa (McConnachie etal., 2011).

The global shipping network is widely recognized as a pathway for vectoring invasive species. One insect species that is known to have spread throughout the world by shipping, including transportation by ships and shipping containers, is the gypsy moth, Lymantria dispar. This species may be introduced into a new area when the port has a suitable climate for the survival and establishment of the species. Two subspecies, with different geographical origins, are known today, and the global distribution threat from the Asian subspecies has been estimated using a CLIMEX model (Paini etal., 2018).

The brown marmorated stink bug heteropteran Halyomorpha halys (Hemiptera: Pentatomidae) is another example of an invasive insect travelling mainly through international trade as a contaminant of non-regulated goods such as machinery, containers and vehicles, but also by passengers and to a lesser extent through movement of plant material. It is highly polyphagous, feeding on more than 300 plant-host species, including food crops, forest trees and ornamentals. This pest has caused serious economic losses in hazelnut crops in Georgia and fruit crops in Italy since its introduction - most likely from North America. A detailed 
report of a pest risk assessment for the introduction and establishment of $\mathrm{H}$. halys can be found in Burne (2019).

\section{Passengers}

People, with their leisure or business travel, are perfect vectors of pests, particularly in the absence of strict controls at points of entry. Leisure travel, in particular, is often associated with people bringing back food, seeds or exotic plants, and these can be infested with pests or can themselves be a pest. To counter this, an increasing number of countries are establishing campaigns at points of entry (airports and harbours), aimed at increasing the public's understanding of the threat to biosecurity posed by the movement of plants and plant parts. Many countries inspect baggage and mail for food and other biosecurity-risk material and encourage incoming passengers to declare potential biosecurity risks. They screen passengers and their baggage using $X$-rays, detector dogs and manual inspections. Passengers with risk materials may be fined or even refused entry. In this respect, countries such as Australia, New Zealand and the United States of America (McCullough etal., 2006) have a long history of strict control, as well as of collecting and reporting data on interceptions.

\section{Natural dispersal}

There are examples where native and non-native pests have significantly expanded their geographical ranges naturally (i.e. not assisted by humans). These are usually in relation to major changes in host distribution or climate. Of the changes in climate, increasing temperatures have particularly facilitated range expansion in pests, especially at higher latitudes and altitudes. In Europe, for example, higher winter temperatures have increased the larval survival and nocturnal adult dispersal of the pine processionary moth, Thaumetopoea pityocampa, allowing the northern expansion of its range (Battisti etal., 2006). In addition, wind and storms can transport spores of pathogens over long distances, even across continents. For example, changing wind or storm patterns are projected to promote the future distribution of wheat stem rust, caused by Puccinia graminis (Prank etal., 2019). Also, myrtle rust (Austropuccinia psidii), detected for the first time in Australia in 2010 on the central coast of New South Wales, is expanding its distribution and can now be found in a range of native forest ecosystems, with disease impacts ranging from minor leaf spots to severe shoot and stem blight and tree dieback (Pegg etal., 2017). The distribution of several pests, including fruit flies, can be affected through hurricanes in the Caribbean, Central America, and the southern United States of America. For example, Flitters (1963), when following the hurricane "Carla", observed that several insect species emerged in unusually large numbers in Texas, suggesting that they had been transported there by the hurricane from distant locations. 


\section{Approaches used to investigate the effects of climate change on plant pests}

Over the past 30 to 40 years, the effects of several factors - increased temperature, $\mathrm{CO}_{2}$, ozone or ultraviolet-B irradiation, and changing water or humidity patterns - on the incidence and severity of plant diseases have been evaluated. Studies have focused on pests affecting field crops such as wheat, barley, rice, soybean and potato (Bregaglio, Donatelli and Confalonieri, 2013; Evans etal., 2008; Launay etal., 2014; Luck etal., 2011; Mikkelsen, Jørgensen and Lyngkjær, 2014), horticultural crops (Gullino etal., 2018; Koo, Hong and Yun, 2016), including tropical and plantation crops (Ghini, Hamada and Bettiol, 2011), and forest trees (Battisti, 2008; Jactel, Koricheva and Castagneyrol, 2019; Sturrock etal., 2011).

A variety of research approaches have been used in such studies, as summarized in Table 1. Some have involved experiments, looking at the effects of changes in one or more weather parameters. Other studies have investigated species along latitudinal or elevational gradients as a proxy for changes in climate over time. In addition to these empirical approaches, "theoretical" approaches have also been adopted, such as the meta-analysis of published results or the analysis of long-term data sets. Finally, some studies have drawn upon expert opinion or have generated simulation models to predict how projected changes in climate or atmospheric composition will alter the distribution, prevalence, severity and management of pests and other organisms.

Experimental approaches can yield useful insights into the effects of climate change on plant diseases and pests, but few such studies have realistically mimicked a changing climate (Chakraborty and Newton, 2011; Ingram, Gregory and Izac, 2008; Loustau etal., 2007; Luck etal., 2011; Pautasso etal., 2012). Climate-change studies carried out in free air $\mathrm{CO}_{2}$ enrichment facility (FACE) systems and in open-topped chambers have led to a better understanding of the effects of different parameters on the development of plant diseases in various crops (Eastburn, McElrone and Bilgin, 2011) (Figure 5). Such systems have also been used to investigate weeds (Williams etal., 2007) and insects (Delucia etal., 2012). In general, most of the insect and disease problems studied in FACE systems under elevated $\mathrm{CO}_{2}$ conditions have shown increases, as recently summarized by Ainsworth and Long (2021).

Phytotrons - environmental chambers built to test the effect of combinations of environmental parameters (Gullino etal., 2011; Hakata etal., 2017) - enable studies of the effects of short-term increases in $\mathrm{CO}_{2}$ and temperature on host-pathogen relationships (Gullino etal., 2018), to understand how specific diseases may evolve in the future (Figure 6). The results of such studies can be used to develop practical solutions to cope with future scenarios, for instance providing support to the plant-breeding industry. They can also allow investigation into other, more indirect, effects of climate change on plants, such as the effects on mycotoxin production or on disease-management practices (Gilardi etal., 2017; Gullino etal., 2020).

Field approaches in natural environments include research along an elevation gradient from low- to high-elevation sites (Betz, Srisuka and Puthz, 2020; Garibaldi, Kitzberger and Chaneton, 2011), with associated changes in temperature and air humidity, and research in different habitats along a latitudinal gradient, including, for 
example, subtropical, temperate and semi-arid climatic conditions (Bairstow etal., 2010; Scalone etal., 2016). The first approach has the advantage of the photoperiod being the same along the elevational gradient. In the second approach, the photoperiod is likely to vary across the latitudinal gradient. In the tropics, for example, days are shorter and nights are longer during summer and the other way round in winter, compared to temperate climatic conditions. These differences in photoperiod need to be considered when interpreting results. Nevertheless, this kind of approach is helpful for identifying broad patterns across wide environmental gradients and a range of climatic regions under real-world conditions, and such studies can help to determine whether a certain species is limited to a specific climate or is widely occurring and may invade locations that are getting warmer (Juroszek and von Tiedemann, 2013a).

Meta-analyses of published data sets have been performed to search for general patterns in the responses of specific pests to differences in climate variables (Koricheva and Larsson, 1998; Massad and Dyer, 2010; Vila etal., 2021). In addition, long-term data sets from field observations have been used to study climate-change effects that are already apparent owing to the warming in recent decades (Altermatt, 2010; Huang and Hao, 2020; Jeger and Pautasso, 2008). Such long-term data sets can serve as a suitable baseline for future studies (Huang and Hao, 2020; Robinet and Roques, 2010) because they can help researchers distinguish impacts due to climate change from those due to other factors (Garrett etal., 2016, 2021). Attempts to improve estimates of climate-warming effects on insects have been made by combining data from long-term data sets, large-scale experiments and computer modelling (Diamond, 2018; Grünig etal., 2020; Lehmann etal., 2020). For example, a meta-analysis of data from laboratory studies concluded that higher trophic levels (e.g. predators) are more susceptible to climate change than lower-order organisms (plants or herbivorous insects) (Fussmann etal., 2014). This is relevant when studying the changing role of natural enemies on insect pest dynamics and biological control under climate change - a subject on which there are very few field data (Thomson, MacFadyen and Hoffman, 2010).

Simulation models can be used to project future climate-change impacts on pests (Sutherst, 1991; Sutherst etal., 2011), and to help determine tactics and strategies to control pests (Ghini, Hamada and Bettiol, 2008; Hill and Thomson, 2015; Salinari etal., 2007; Shaw and Osborne, 2011). One modelling approach, for example, uses "climate matching", whereby a geographical area that has a present-day climate analogous to the future climate in the area of interest is studied (for pest dynamics in this case), and then the findings extrapolated to a future scenario in the area of interest (Sutherst, Maywald and Russell, 2000). Other modelling approaches may rely on long-term data sets for weather parameters, crop development, and pest distribution and prevalence to develop and validate "pest-crop-climate" models (Angelotti etal., 2017; Madgwick etal., 2011). Other recent examples of modelling studies, listed in Table 2, consider parameters such as the number of generations per year for insect pests, the timing of plant flowering and related disease severity, and the global distribution of weeds. 
Table 1. Examples of experimental and theoretical approaches in climate-change biology research

TYPE OF RESEARCH APPROACH

Experiments under controlled conditions

Experiments on-station, on-farm, and under natural conditions

Studies along an elevation gradient from low to high elevation sites

from low to high elevation sites

Studies along a latitudinal gradient



Meta-analysis of published data

Data monitoring, long-term data
sets of different parameters

Expert opinion

Expert opinion
"Climate matching" approach
Modelling approach using one or
several climate-change scenarios
or models, or comprehensive
ensembles of climate-change
scenarios or models, to simulate
future pest risk

DESCRIPTION AND COMMENTS

SELECTED REFERENCES

Controlled conditions are not realistic, but it is easier to

study one or few environmental parameters because of lower Gullino etal., 2018. variability and fewer interactions.

Field conditions are realistic, but the environmental parameters are difficult to control because of variability and complex interactions.

Raderschall etal., 2021; Torresen etal., 2020.

Effects of changes in temperature and precipitation can be studied over a short distance, with day length the same (e.g. characteristics of a single species can be compared).

Betz, Srisuka and Puthz, 2020.

Research along a climate gradient from temperate to tropical is possible, with long-distance changes in temperature and precipitation, but day length can be different in different locations (e.g. characteristics of a single species, or the biodiversity of species in general, can be compared in different climates)

Involves searches for general patterns in responses of specific taxa to variations in climate factors. A sufficient number of published results should be available to draw meaningful conclusions.

Involves long-term field observations to study effects already apparent due to climate warming in recent decades. Long-term weather records are necessary and, if available, other long-term data sets to search for other possible reasons for observed changes (particularly in managed systems).

Long-term experiences and knowledge of experts can be used. The complete life cycle of a pest species can be considered in theory; but this approach is somewhat subjective.

Scalone etal., 2016.

A present-day climate analogue to the future climate for an area of interest is found, and the pest dynamics in that location studied in order to gain an appreciation of the comparative dynamics (e.g. dynamic climate matching model CLIMEX). Other tools can also be used, such as MaxEnt, which compares the habitat suitability of different locations for the species of interest.

It is possible to categorize scenarios or models used from "conservative" to "worst case", and this is also possible within a single climate-change model if different representative concentration pathway (RCP) scenarios are applied (RCP 2.6, RCP 4.5, RCP 6.0, RCP 8.5). However, using one specific climate-change scenario in only a single climate model is no Seidl etal., 2017 longer deemed adequate, because it does not incorporate the variation that is possible. Therefore, comprehensive ensembles of climate-change scenarios or models are often used.

三 CLIMEX, climate modelling of extreme events; RCP, representative concentration pathway.

Note: The references were subjectively selected, with a preference for post-2000 studies.

E Source: Modified after Juroszek and von Tiedemann, 2013a. 
Figure 5A

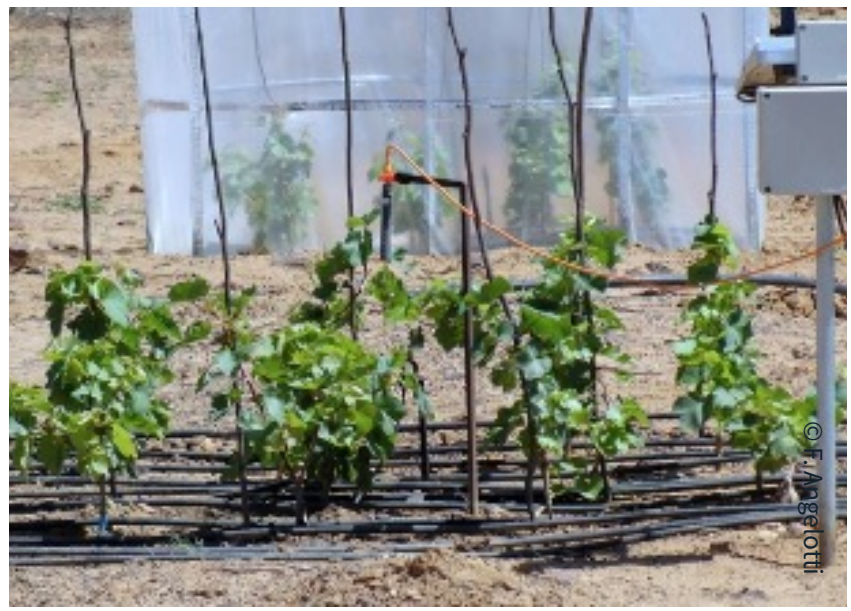

Figure 5B

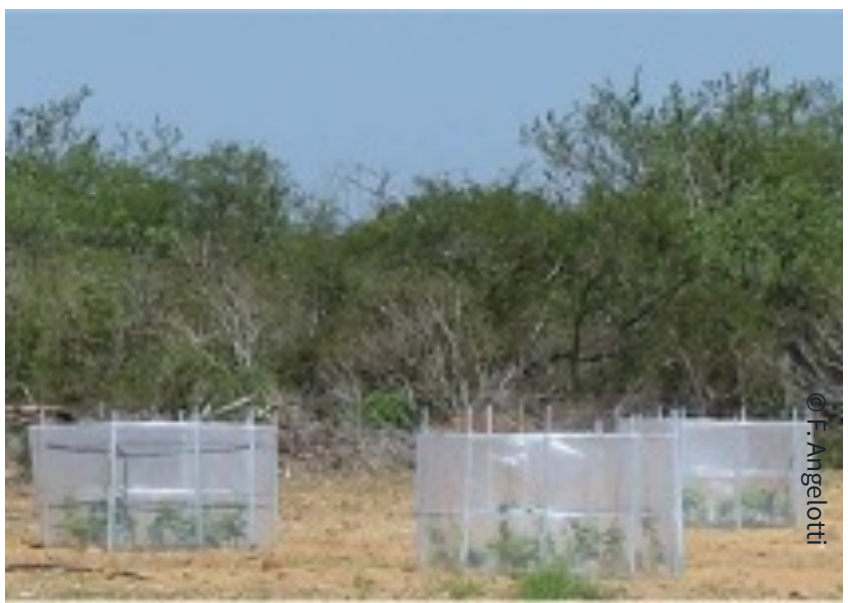

Open top chambers for studying the impacts of

increased air $\mathrm{CO}_{2}$ concentration in Petrolina, Brazil

Figure 6

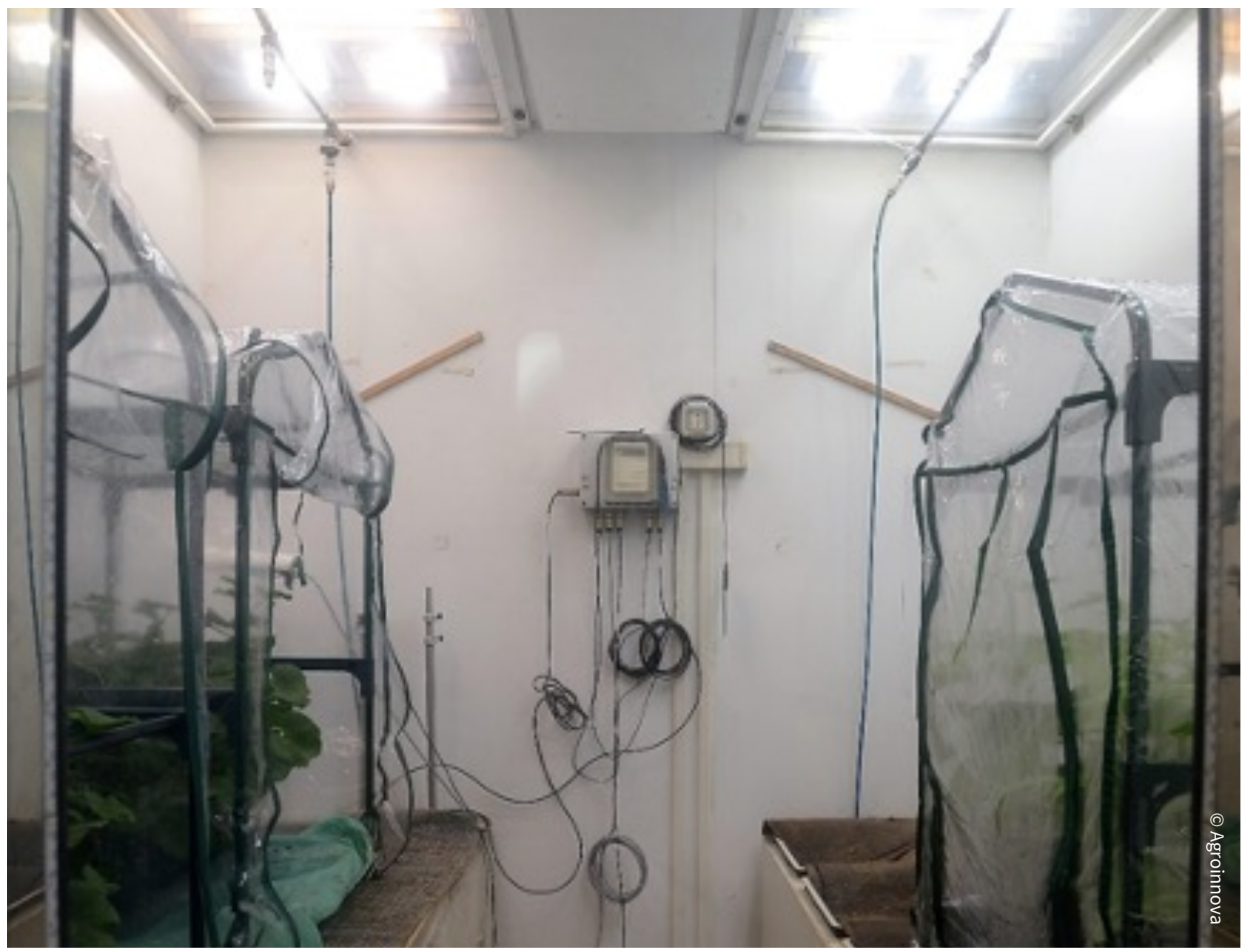

Phytotrons used for vegetative growth under controlled conditions

By simulating multiple environmental factors, phytotrons allow the effects of climate

change on plants and their pathogens to be studied. 
Table 2. Examples of pest risk simulation studies where pest models were linked to climate-change scenarios

\begin{tabular}{|c|c|c|c|}
\hline COUNTRY OR REGION & TIME SPAN OR SPANS & CROPS AFFECTED, PEST SPECIES AND PROJECTION OF CHANGE & SELECTED REFERENCE \\
\hline & & INSECTS & \\
\hline Switzerland & 2070-2099 & $\begin{array}{l}\text { Multiple crops: Brown marmorated stinkbug (Halyomorpha halys), } \\
\text { which has a wide range of potential hosts, is projected to expand } \\
\text { into higher altitudes, produce more generations per year, and be } \\
\text { active earlier in spring. }\end{array}$ & $\begin{array}{l}\text { Stoeckli, Felber and Haye, } \\
2020 .\end{array}$ \\
\hline Global & 2050,2100 & $\begin{array}{l}\text { Multiple crops: Area suitable for fall armyworm (Spodoptera } \\
\text { frugiperda) is projected to increase. }\end{array}$ & Zacarias, 2020. \\
\hline Global & 2050 & $\begin{array}{l}\text { Tomato: It is projected that several nations face a potential } \\
\text { increase in two-spotted spider mite (Tetranychus urticae) } \\
\text { outbreaks, while biological control by its key predator Phytoseiulus } \\
\text { persimilis will not improve. }\end{array}$ & Litkas et al., 2019. \\
\hline
\end{tabular}

\begin{tabular}{|c|c|c|c|}
\hline $\begin{array}{l}\text { United States of } \\
\text { America, Midwest }\end{array}$ & 2001-2050, 2051-2100 & $\begin{array}{l}\text { Corn and soybean: Pressure of nine different insect pests is } \\
\text { projected to increase in general. Insect pests will move northward, } \\
\text { because "optimal climatic conditions" will be further north. }\end{array}$ & Taylor et al., 2018. \\
\hline \multirow[t]{2}{*}{ Global } & 2041-2060, & \multirow{2}{*}{$\begin{array}{l}\text { Potato: Expansion of Colorado potato beetle (Leptinotarsa } \\
\text { decemlineata) into northern regions is projected. }\end{array}$} & \multirow{2}{*}{ Wang etal., 2017.} \\
\hline & 2061-2080 & & \\
\hline Africa & $2041-2060$ & $\begin{array}{l}\text { Multiple crops: Habitat suitability for Bactrocera dorsalis, Ceratitis } \\
\text { cosyra and Tuta absoluta is projected to partially increase across } \\
\text { the continent. }\end{array}$ & $\begin{array}{l}\text { Biber-Freudenberger etal., } \\
2016 .\end{array}$ \\
\hline Luxembourg & 2021-2050, 2069-2098 & $\begin{array}{l}\text { Oilseed rape: Meligethes aeneus is projected to invade crops } \\
\text { earlier in the year. }\end{array}$ & $\begin{array}{l}\text { Junk, Jonas and Eickermann, } \\
2016 .\end{array}$ \\
\hline \multirow[t]{2}{*}{$\begin{array}{l}\text { Scandinavia and } \\
\text { central parts of } \\
\text { Europe }\end{array}$} & 2011-2040, 2071-2100 & $\begin{array}{l}\text { Forest trees, spruce: Increased frequency and length of } \\
\text { late-summer swarming events of the European spruce bark beetle } \\
\text { (Ips typographus) is projected. A second generation in southern } \\
\text { Scandinavia is possible and a third generation in the lowlands of } \\
\text { central Europe. }\end{array}$ & Jönsson etal., 2011. \\
\hline & & \multicolumn{2}{|l|}{ PATHOGENS (DISEASES) } \\
\hline France & $\begin{array}{l}2020-2049 \\
2070-2099\end{array}$ & $\begin{array}{l}\text { Wheat: Risk of leaf rust (caused by Puccinia triticina) is projected } \\
\text { to increase. }\end{array}$ & Launay etal., 2020. \\
\hline France & $\begin{array}{l}2020-2049 \\
2070-2099\end{array}$ & $\begin{array}{l}\text { Apricot: Risk of blossom blight and twig blight (caused by } \\
\text { Monilinia laxa) is projected to decrease or increase, depending on } \\
\text { the cultivar grown (early vs late flowering). }\end{array}$ & Tresson etal., 2020. \\
\hline $\begin{array}{l}\text { Canada, } \\
\text { Quebec }\end{array}$ & $2041-2070$ & $\begin{array}{l}\text { Soybean: The number of generations of soybean cyst nematode } \\
\text { (Heterodera glycines) is projected to increase. }\end{array}$ & St-Marseille etal., 2019. \\
\hline Global & $\begin{array}{l}2050 \\
2100\end{array}$ & $\begin{array}{l}\text { Soybean: Area favourable for soybean rust (caused by Phakopsora } \\
\text { pachyrhizi) is projected to decrease. }\end{array}$ & $\begin{array}{l}\text { Ramirez-Cabral, Kumar and } \\
\text { Shabani, } 2019 .\end{array}$ \\
\hline Philippines & 2050 & $\begin{array}{l}\text { Banana: Area favourable for Fusarium wilt (caused by Fusarium } \\
\text { oxysporum) is projected to increase. }\end{array}$ & Salvacion etal., 2019. \\
\hline China, central & $\begin{array}{l}2030 s \\
2050 s \\
2070 s \\
2080 s\end{array}$ & $\begin{array}{l}\text { Kiwi: Area favourable for bacterial canker (caused by } \\
\text { Pseudomonas syringae) is projected to increase. }\end{array}$ & Wang etal., 2018. \\
\hline Europe & 2070 & $\begin{array}{l}\text { Pine trees: Pine wilt disease risk (caused by the pine wilt } \\
\text { nematode, Bursaphelenchus xylophilus) is projected to increase. }\end{array}$ & Ikegami and Jenkins, 2018. \\
\hline Brazil & $\begin{array}{l}2011-2040 \\
2041-2070 \\
2071-2100\end{array}$ & $\begin{array}{l}\text { Grapevine: Area favourable for downy mildew (caused by } \\
\text { Plasmopara viticola) is projected to decrease across Brazil, } \\
\text { although there are differences across regions or states. }\end{array}$ & Angelotti etal., 2017. \\
\hline Italy & $\begin{array}{l}2030 \\
2050 \\
2080\end{array}$ & $\begin{array}{l}\text { Grapevine: Increased importance of downy mildew (Plasmopara } \\
\text { viticola), due to more spring days with favourable conditions, with } \\
\text { earlier attacks and more treatments needed. }\end{array}$ & Salinari etal., 2006. \\
\hline India & $\begin{array}{l}2010-2039 \\
2040-2069\end{array}$ & $\begin{array}{l}\text { Rice: Infection ability of leaf blight (caused by Magnaporthe } \\
\text { oryzae) is projected to increase during the winter season } \\
\text { (December to March), whereas during the monsoon season } \\
\text { (July to October) it is projected to remain unchanged or to } \\
\text { decrease slightly. }\end{array}$ & Viswanath etal., 2017. \\
\hline $\begin{array}{l}\text { Germany, } \\
\text { south-west }\end{array}$ & 2050,2100 & $\begin{array}{l}\text { Sugar beet: Risk of Cercospora leaf spot (caused by Cercospora } \\
\text { beticola) is projected to increase. }\end{array}$ & Kremer etal., 2016. \\
\hline
\end{tabular}


For 32 invasive weed species, the area suitable for growth is

projected, in general, to decrease on a global scale. However,

in European countries, northern Brazil, eastern United States of

Shabani etal., 2020.

America, and south-east Australia, the suitable area is projected to increase for most of these 32 weed species.

\begin{tabular}{|c|c|c|c|}
\hline China & $2070-2099$ & $\begin{array}{l}\text { For six out of a total of eight alien invasive weed species, the area } \\
\text { suitable for growth is projected to increase. }\end{array}$ & Wan and Wang, 2019. \\
\hline Global & $\begin{array}{l}2041-2060 \\
2061-2080\end{array}$ & $\begin{array}{l}\text { Suitable habitat of prickly nightshade (Solanum rostratum) } \\
\text { is projected to expand into the circumpolar latitudes. }\end{array}$ & Wan and Wang, 2019. \\
\hline Global & 2050 & $\begin{array}{l}\text { Area suitable for lantana (Lantana camara) is projected to } \\
\text { increase, although there will be considerable variation among } \\
\text { continents. }\end{array}$ & Qin etal., 2016. \\
\hline Global & 2100 & $\begin{array}{l}\text { Area suitable for rigid ryegrass (Lolium rigidum) is projected to } \\
\text { increase in North America, South America, Europe and Asia, while } \\
\text { in Africa and Oceania it is projected to decrease. }\end{array}$ & Castellanos-Frías. etal., 2016. \\
\hline $\begin{array}{l}\text { United States of } \\
\text { America, Colorado }\end{array}$ & 2050 & Area suitable for Bromus tectorum is projected to increase. & West etal., 2015. \\
\hline Europe & 2010-2030, 2050-2070 & $\begin{array}{l}\text { Area suitable for common ragweed (Ambrosia artemisiifolia) is } \\
\text { projected to expand northward and is projected to continue to be } \\
\text { limited by drought stress in southern Europe. }\end{array}$ & Storkey etal., 2014. \\
\hline Argentina, central & $2020-2040$ & $\begin{array}{l}\text { Performance of Johnson grass (Sorghum halepense) is projected } \\
\text { to improve. }\end{array}$ & $\begin{array}{l}\text { Leguizamon and Acciaresi, } \\
2014 .\end{array}$ \\
\hline
\end{tabular}

三 Note: The studies listed were subjectively selected, with a preference for recent publications. More summary tables with simulation results can be found 无 in the literature: pathogens or diseases (e.g. Juroszek and von Tiedemann, 2015; Miedaner and Juroszek, 2021a), insect pests (e.g. Choudhary, Kumari and 豆 Fand, 2019), weeds (e.g. Clements, DiTommaso and Hyvönen, 2014). 


\section{Effects of climate}

change on plant

pests 


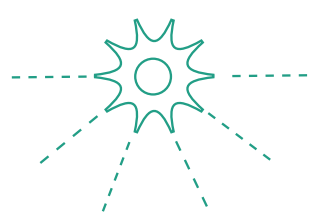

his section of the report explores the potential effects of climate change on
pests and hence on plant health, first in terms of broad trends and then by
reviewing the effects on a selection of individual species or groups of species, provided as case studies.

\section{Simulation of future pest risk}

Simulation studies to determine future pest risks under climate-change scenarios have mostly employed species-distribution models, population-dynamics models, or hybrids of both (Table 2). Climatic factors considered in these studies include temperature, precipitation and humidity, but elevated $\mathrm{CO}_{2}$ is usually not considered (Eastburn, McElrone and Bilgin, 2011; Juroszek and von Tiedemann, 2015). The effects of climate change are probably easier to predict for those pest species that are mainly affected by temperature. Prediction is more difficult for pests whose reproduction and dispersal are strongly related to water availability, wind and crop management. This is also true for pests that are strongly affected by interactions with other organisms such as vectors of pathogens (Trebicki and Finlay, 2019), unless their interactions are well studied (Juroszek and von Tiedemann, 2013a) and thus predictable (see case study for Xylella fastidiosa).

The outcome of simulations is dependent on the materials and methods used, including the global climate model used, the emission scenarios, the regional climate model, and the specific pest model, together with the precise parameters used in the simulation (Miedaner and Juroszek, 2021a). All of these contribute to the outcome of pest risk projections (Gouache etal., 2013; Juroszek and von Tiedemann, 2013b; Launay et al., 2020) and should be borne in mind when reading and interpreting the results from simulation studies such as those listed in Table 2. In addition, it should be noted that the effect of climate change on pest risk can vary across a country (e.g. lowlands vs mountains, north vs south, summer vs winter, hot and wet vs cool and dry season), as recently highlighted by Miedaner and Juroszek (2021a).

According to Juroszek and von Tiedemann (2015), in general the projected change (increase or decrease) in pest risk will be more pronounced by the end of the twenty-first century than earlier in the century if increasing temperature is the main driver of results. This reflects the fact that global warming is projected to be greater by the end compared to the middle and the beginning of the twenty-first century $\left(\right.$ e.g. $3^{\circ} \mathrm{C}$ vs $2^{\circ} \mathrm{C}$ vs $1^{\circ} \mathrm{C}$ global temperature increase, respectively).

The projected changes to pest risk vary according to geographical location (Sidorova and Voronina, 2020). For example, in an early simulation study of future pest risk driven by a climate-change scenario, an increased risk of rice blast disease, caused by the fungus Magnaporthe grisea, was predicted for cool, subtropical rice-growing regions such as Japan, whereas in the humid, warm tropics, such as in the Philippines, rice blast risk was predicted to decrease in the future (Luo etal., 1995, 1998). Regarding insect pests, projections by Kocmánková etal. (2011) suggest that the European corn borer (Ostrinia nubilalis) and Colorado potato beetle (Leptinotarsa decemlineata) will probably increase their ranges in many parts of Europe, colonize 
higher altitudes, and increase their annual number of generations, as a result of a projected temperature increase. On the other hand, climate warming may cause temperature increases which are near the upper lethal limit of some insect species, especially during the summer in temperate climates (Bale and Hayward, 2010; Harvey etal., 2020) and in the already very warm tropics (Deutsch etal., 2008). This variation in impact with geographical location means that generalizations should be treated with extreme caution and researchers need to be very careful when extrapolating their results (Juroszek etal., 2020).

Recently, Seidl etal. (2017) published a comprehensive, global analysis of available results (more than 1600 single observations) and concluded that around two-thirds of all observations show that the risk of abiotic (e.g. fire, drought) and biotic (e.g. insect pests, pathogens) stress factors will increase in forestry worldwide. Warmer and drier conditions favour disturbances by insects, whereas warmer and wetter conditions favour disturbances from pathogens. The same trend is expected for many crop diseases (e.g. Juroszek and von Tiedemann, 2015), insect pests (e.g. Choudhary, Kumari and Fand, 2019) and weeds (e.g. Clements, DiTommaso and Hyvönen, 2014), with increasing pest risk in most cases. Thus, preventive, mitigation and adaptation measures are needed in the future to reduce the projected increases in pest risk in agriculture, horticulture, forestry as well as in urban areas and national parks (Edmonds, 2013; Pautasso, 2013). There is currently an ongoing debate between conservationist movements and plant-health services on how to treat pest infestations in national parks and protected areas and the emotive subject of whether to intervene in currently unmanaged ecosystems.

\section{Effects on pest species}

Climate-change effects on pest species are complex and include direct and indirect effects and their possible interactions. At a given location, a shift in warming and other climate and atmospheric conditions may result in direct or indirect effects on insect pests, pathogens, and weeds. Possible direct and indirect effects on pests include: changes in their geographical distribution, such as range expansion or retreat, or increased risk of pest introduction; changes in seasonal phenology, such as the timing of spring activity or the synchronization of pest life-cycle events with their host plants and natural enemies; and changes in aspects of population dynamics, such as overwintering and survival, population growth rates, or the number of generations of polycyclic species (Juroszek and von Tiedemann, 2013a; Richerzhagen etal., 2011).

In general, all important life-cycle stages of insect pests, pathogens, and weeds (survival, reproduction and dispersal) are more or less directly influenced by temperature, relative humidity, light quality or quantity, wind or any combination of these factors. The physiological processes of most pest species are particularly sensitive to temperature (Juroszek etal., 2020). For example, plant viruses and their insect vectors may be particularly favoured by high temperatures until their upper temperature threshold is reached (Trebicki, 2020). In a three-year field experiment in maize under tropical climatic conditions, Reynaud etal. (2009) showed that the incidence of maize streak disease (caused by the Maize streak virus) and the abundance of its vector, the leafhopper Cicadulina mbila, were closely associated with temperature, both increasing quickly above $24^{\circ} \mathrm{C}$, but that temperatures of $30^{\circ} \mathrm{C}$ and above might 
be detrimental for the leafhopper and related virus transmission (Juroszek and von Tiedemann, 2013c). It might be expected, therefore, that global warming will promote many insect vectors and the viruses they transmit, at least within a certain temperature range.

Indirect effects are mediated through the host plant or through climate-change driven adaptations to crop management (Juroszek etal., 2020). Warmer mean air temperatures, especially in early spring under temperate climatic conditions, may result in life-cycle stages in the host plant occurring earlier in the season (Racca etal., 2015). This can affect pathogens that infect the host during a particular life-cycle stage, for instance wheat pathogens such as Fusarium species that infect wheat during flowering (Madgwick etal., 2011; Miedaner and Juroszek, 2021a). Crop-management adaptations driven by climate change include the introduction of irrigation, cessation of deep soil tillage, shifting of sowing dates, and the cultivation of more than one crop per year. Irrigation of maize in south-east Africa, for example, has permitted year-round cultivation of maize, but has also led to an increase in insect-vector populations, culminating in increased Maize streak virus pressure in irrigated and subsequently also in rainfed crops (Shaw and Osborne, 2011).

Interactions between factors affecting pests may be complex. For example, experiments under real-world field conditions in FACE facilities have shown the complexity of interactions between weed growth and temperature, water and $\mathrm{CO}_{2}$ under changed environmental conditions (Williams etal., 2007), and other experiments have shown that water stress can alter the competitive relationships between weed and crop plants in terms of their response to elevated $\mathrm{CO}_{2}$ concentration (Valerio etal., 2011). Under well-watered conditions, the growth of the $C_{3}$ tomato crop (Lycopersicon esculentum) benefits more from elevated $\mathrm{CO}_{2}$ relative to the $\mathrm{C}_{4}$ weed $\mathrm{Am}$ aranthus retroflexus, whereas under water stress $A$. retroflexus benefits more from elevated $\mathrm{CO}_{2}$ compared to tomato. Experiments such as these (Valerio etal., 2011; Williams etal., 2007), conducted under controlled and field conditions, therefore suggest that plant responses to elevated $\mathrm{CO}_{2}$ are not predictable on the sole basis of the type of photosynthetic pathway $\left(\mathrm{C}_{3} \vee \mathrm{C}_{4}\right)$, because there are complicated interactions with factors such as water availability and temperature, among others. These conclusions are in agreement with a recently published meta-analysis (Vila etal., 2021), especially performed to understand the combined impacts of weeds and climate change on crops. 


\section{Case studies of individual pest species}

Some pests have already expanded their host range or distribution, at least in part due to changes in climate. Examples of these pests, selected according to their relevance in different geographical areas, are summarized below. Examples of some likely effects of climate change on plant pests (insects, pathogens and weeds) in different climate zones are listed in Table 3.

\section{Insects}

\section{Emerald ash borer (Agrilus planipennis) (Asia, Europe, North America)}

The emerald ash borer, Agrilus planipennis, is a phloem-feeding beetle that infests ash trees (Fraxinus spp.) (EPPO, 2021b). The adult beetles feed on the ash foliage, but it is the extensive larval feeding in the phloem and cambium that disrupts translocation in the tree, girdling the tree (i.e. removing a ring of bark around the entire circumference of the branch of trunk) and resulting in its death.

Native to north-east China, the Korean peninsula and the east of the Russian Federation, the emerald ash borer has spread to other parts of Asia, North America (Canada and the United States of America) (Haack etal., 2002) and Europe (e.g. the western and southern parts of the Russian Federation, and Ukraine) (CABI, 2021b). It was probably introduced into North America, for example, in 2002 via wood packaging material, and dendrological studies indicate that it arrived on the continent about a decade before its detection. The subsequent spread of the beetle to various parts of the United States of America and Canada was probably facilitated by the movement of infested nursery stock, logs and firewood (Herms and McCullough, 2014; Ramsfield etal., 2016).

The impacts of the beetle are severe. Aukema etal. (2011) considered it to be the most destructive and costly invasive forest insect in the United States of America, with projections of economic losses from this insect up to 2020 exceeding USD 12.5 billion. The invasion of this beetle has also had important implications for biodiversity in the affected areas, as ash trees provide food, shelter and habitat for many species. Furthermore, it has been suggested that the invasion of the emerald ash borer and the consequent loss of trees has possible implications for human health (Donovan etal., 2013). Management strategies have focused on containment, for example by using quarantine zones, and on reducing population densities, such as through the introduction of biological control agents. Eradication was initially attempted and later abandoned (Herms and McCullough, 2014).

The distribution of ash trees is the main limitation on the range of the emerald ash borer, but climate is also thought to play an important role. In its native range, the emerald ash borer occurs in only a fraction of the range of the ash, but modelling by Liang and Fei (2014) has projected that climate change would result in a more northerly distribution of the beetle in North America, and a subsequent long-lasting risk to ash in those areas. However, it is expected that the southward invasion of the emerald ash borer in North America would be limited within a warming climate-change scenario, as the beetle requires strong seasonality with a long winter season. Research by Duan etal. (2020) on the overwintering survival of several introduced larval parasitoid species of the emerald ash borer after an extreme climate event (low winter temperatures) has also shown that extreme climate events associated with climate change could reduce the efficacy of biological control of the beetle. 


\section{Tephritid fruit flies (global)}

Tephritids are a diverse family of insects, with more than 4000 described species. Most of the species feed on plants and several can cause substantial economic damage, especially when their larvae develop in fruits of high market value. The family contains several invasive species, such as Bactrocera oleae (Figure 7 and Gutierrez etal., 2009), which feeds only on olive trees (and a few wild relatives), Bactrocera dorsalis, which feeds on several dozen fruit plant species, and the Mediterranean fruit fly, Ceratitis capitata, which feeds on a moderate number of tree crops.

Tephritids have been able to expand geographically from their original distribution to colonize both neighbouring areas and new regions owing to the expansion of cultivation of their hosts, international trade, and because climate change has allowed their winter survival and reproduction in habitats otherwise unsuitable for the species. Bactrocera oleae occurs in Africa, Europe and Asia and has invaded California and Mexico more recently (CABI, 2021c). However, Godefroid etal. (2015) concluded that the species may establish not only in the temperate Mediterranean-climate regions but also in the colder climates of northern latitudes in Europe, where olive trees are yet to be cultivated.

Bactrocera dorsalis is a pest of major concern throughout south-east Asia and further west through to Pakistan and north to southern China and Nepal; it has been reported in other areas, including most of Africa, the eastern United States of America, and several islands in the Pacific (EPPO, 2021C). As it has a wide host range, it is being intercepted often in international markets. Because the climatic range of B. dorsalis is primarily tropical and subtropical and it is considered to have rather complex requirements, the risk of direct economic losses from an incursion into temperate areas is low, but climate modification by global warming could allow a rapid increase in fly populations in mild seasons, with the flies spending the winter protected in fruits stored in sheltered places (EPPO, 2021c). This is also the case for $C$. capitata, which occurs in southern and central Europe, most of Africa and the Near East, Central and South America, and Western Australia, but can overwinter in colder regions as larvae, in fruits stored in warm places. It can spread through the international trade of oranges, mandarins and lemons (Fedchock etal., 2006).

\section{Red palm weevil (Rhynchophorus ferrugineus) (Near East, Africa, Europe)}

The red palm weevil, Rhynchophorus ferrugineus, is one of the most economically damaging insect pests of palm trees. Native to south-east Asia and Melanesia, larvae of this weevil feed within the apical growing point of the tree, causing extensive damage to the plant tissue, weakening the structure of the plant and in many cases resulting in tree death. In the Gulf region of the Near East, the annual losses due to death and removal of palms severely infested by red palm weevil have been estimated to range from USD 5.2 million to 25.9 million at 1 and 5 percent infestation, respectively (El-Sabea, Faleiro and Abo-El-Saad, 2009). Another estimate has considered the annual losses due to red palm weevil to be USD 15 million (Al-Ayedh, 2017).

The red palm weevil infests various palm species, including coconut and date palm (El-Mergawy and Al-Ajlan, 2011; FAO, 2020). It was first detected on date palms in the Near East in the mid-1980s, and subsequently spread to other countries in the Near East, and to Africa and Europe. In 2010, it was detected in California in the United States of America, where it was declared eradicated in 2015. 
Its global distribution has probably been assisted by movement of palm offshoots as planting material. Management strategies include the use of various cultural and phytosanitary measures, such as removal of infested trees, the application of insecticides and of nematodes pathogenic to insects, and the use of pheromone traps (FAO, 2020; Ge etal., 2015).

The distribution of the red palm weevil may expand because of climate change. Ge etal. (2015) predicted that in China the number of areas highly favourable to this pest would increase with climate change, resulting in the expansion of the insect into north China. Among the Rhynchophorus species, the red palm weevil is the only one that has significantly expanded its geographical range from its original home in south and south-east Asia (Wattanapongsiri, 1966). It has been reported in 45 countries and ecological-niche modelling predicts that it could expand its range even further (Fiaboe etal., 2012). The red palm weevil is still considered to be the major challenge for palm growers in the Near East, and despite all means of integrated control, its damaging effects are still causing great economic losses.

\section{Fall armyworm (Spodoptera frugiperda) (Americas, Africa, Asia)}

The fall armyworm (Spodoptera frugiperda) is a moth belonging to the family Noctuidae (Figure 7). It has a host range of hundreds of plant species, inflicting severe damage in grasses - particularly maize and sorghum, which are the preferred hosts - along with other crops, such as rice, cotton and soybean preferred by different species strains. It is native to tropical and-subtropical areas of the Americas and during summer it migrates into southern and northern temperate American regions. The pest was first reported in western Africa in 2016 (Goergen etal. 2016) and then throughout sub-Saharan Africa and Egypt in 2019. In 2018, it was reported in India, rapidly spreading all over southern and eastern Asia including China, the Republic of Korea, Japan and Pakistan. It has also been reported in Bangladesh, Indonesia, Myanmar, Sri Lanka, Thailand, the Philippines, Viet Nam and Yemen (EPPO, 2020a). In 2020, the fall armyworm was first detected on maize in Jordan and the United Arab Emirates (IPPC Secretariat, 2020a; 2020b) and in Israel (EPPO, 2020b). It has also spread across the Australian continent (IPPC Secretariat, 2021).

The fall armyworm is adapted to warm climates and not able to enter diapause, and its geographical distribution is closely dependent on climatic conditions. Adults can travel up to several kilometres in a single night and seasonal migrations can reach Canada from the southern United States of America. Ramirez-Cabral, Kumar and Shabani (2017) have highlighted the expansion of its geographical range in warmer climates because of its adaptability to different environments, its high dispersal capacity, the wide range of potential hosts and the intense international trade of commodities attacked by the larvae or pupae of the moth. They have also predicted a reduction or even partial disappearance of the species in the southern American hemisphere, due to the warmer and drier conditions expected there in the middle or end of this century in the north of the sub-continent. In the European Union, some warm areas in Spain, Italy and Greece could provide suitable climatic conditions for the establishment of the species, mainly from populations established in the North of Africa (Jeger etal., 2018). 
The desert locust (Schistocerca gregaria) is found mainly in Africa, through Arabia and western Asia, extending into parts of southern Asia (FAO, 2021a). It has been reported occasionally in south-west Europe. It swarms and voraciously feeds on key crops such as maize and sorghum, pastures, and any green vegetation that comes its way, thereby significantly affecting smallholder farmers and pastoralists (Kimathi etal., 2020).

The desert locust shows periodic changes in its body form and can change over generations, in response to environmental conditions, from a solitary, highly fecund, non-migratory form to a gregarious, migratory phase in which it may travel long distances, finally invading new areas. In general, the desert locust breeds extensively in semi-arid zones, extending from western Africa through the Near East to south-west Asia, threatening the livelihoods of people in over 65 countries. However, there is also a much less well-known subspecies, S. gregaria flaviventris, that occupies a limited area in southern Africa, and the potential of this subspecies to pose a threat in the future should be investigated (Meynard etal., 2017).

Large outbreaks of desert locust have been recorded over many centuries, and the FAO keeps a long-term, large-scale monitoring survey database on affected areas. Identifying the potential breeding sites of the pest is essential if cost-effective and timely preventive measures are to be carried out before the pest inflicts significant damage (Kimathi etal., 2020). Since the 1960s, outbreaks have been less frequent, but in 2019-2020 unprecedented locust breeding was observed in Eritrea, Somalia and Yemen, due to unusually heavy rainfall in the Horn of Africa. The current strategy for managing swarms of the locust is aerial spraying with chemical pesticides, which has high negative impacts on humans, livestock, the environment and biodiversity.

The behaviour, ecology and physiology of the desert locust changes in response to some climatic conditions. Attribution of a single event to climate change is difficult, but climatic changes such as increases in temperature and rainfall over desert areas, and the strong winds associated with tropical cyclones, provide a new favourable environment for pest breeding, development and migration. This suggests that global warming has played a role in providing the conditions required for the development, outbreak and survival of the locust. But the impact of climate change is complex and the FAO's Commission for Controlling the Desert Locust in south-west Asia (FAO, 2021a) has therefore highlighted the need for international cooperation across affected countries to tackle the locust threat. Where it will fly next depends on wind direction, speed, and other weather parameters. Consequently, climate change may have an impact on future migration routes of the desert locust. The prediction of risk under different climate-change scenarios, however, may need to differentiate between different subspecies, because each of them may have different niche requirements. 
Table 3. Examples of some likely effects of climate change on plant pests (insects, pathogens and weeds) in different climate zones

\begin{tabular}{|c|c|c|}
\hline CLIMATE ZONES & $\begin{array}{l}\text { LIKELY EFFECTS OF CLIMATE CHANGE ON FUTURE PEST RISK (MAINLY } \\
\text { 2050-2100) }\end{array}$ & REFERENCES \\
\hline Artic & More increasing pest risk in the tundra & Revich, Tokarevich and Parkinson, 2012. \\
\hline Boreal & More increasing insect pest and plant disease risk in boreal forests & Seidl etal., 2017. \\
\hline \multirow[t]{6}{*}{ Temperate } & More increasing insect pest risk in agriculture and forestry & Grünig etal., 2020. \\
\hline & More increasing insect pest and plant disease risk in forests & Seidl etal., 2017. \\
\hline & $\begin{array}{l}\text { More increasing disease risk in agriculture and horticulture (mostly based } \\
\text { on western European studies) }\end{array}$ & $\begin{array}{l}\text { Juroszek and von Tiedemann, 2015; } \\
\text { Miedaner and Juroszek, 2021a. }\end{array}$ \\
\hline & $\begin{array}{l}\text { Often poleward shift of insect pest and pathogen risk in different managed } \\
\text { and unmanaged ecosystems }\end{array}$ & Bebber, Ramotowski and Gurr, 2013. \\
\hline & $\begin{array}{l}\text { Often range expansion of important insect pests in agriculture and } \\
\text { horticulture }\end{array}$ & Choudhary, Kumari and Fand, 2019. \\
\hline & $\begin{array}{l}\text { More increasing risk of weeds in different managed and unmanaged } \\
\text { ecosystems }\end{array}$ & $\begin{array}{l}\text { Clements, DiTommaso and Hyvönen, } \\
2014 .\end{array}$ \\
\hline \multirow[t]{3}{*}{ Subtropical } & $\begin{array}{l}\text { Increasing saturation of insect pest risk in agriculture and forestry in } \\
\text { southern Europe }\end{array}$ & Grünig etal., 2020. \\
\hline & More increasing disease risk in agriculture and horticulture & Gullino etal., 2018. \\
\hline & $\begin{array}{l}\text { Often range expansion of important insect pests in agriculture and } \\
\text { horticulture }\end{array}$ & Choudhary, Kumari and Fand, 2019. \\
\hline \multirow[t]{2}{*}{ Tropical } & $\begin{array}{l}\text { Insects will often face supra-optimal temperature conditions in the future, } \\
\text { presumably resulting in decreasing insect pest risk }\end{array}$ & Deutsch etal., 2008. \\
\hline & $\begin{array}{l}\text { More decreasing disease risk in agriculture and horticulture (based on } \\
\text { Brazilian simulation studies); however, also more increasing disease risks } \\
\text { (based on both simulation studies and expert opinions) (e.g. due to location- } \\
\text { dependent outcomes) }\end{array}$ & $\begin{array}{l}\text { Angelotti etal., 2017; Ghini etal., 2011; } \\
\text { Juroszek and von Tiedemann, } 2015 .\end{array}$ \\
\hline
\end{tabular}

三 Notes: Derived from references (examples) that analysed or summarized many, or at least several, results within a discipline or across disciplines.

Most results are related to the northern hemisphere, especially the temperate zone. In India, increasing insect pest risks have already been observed, but 豆 without discriminating between climatic zones (e.g. Rathee and Dalal, 2018). 


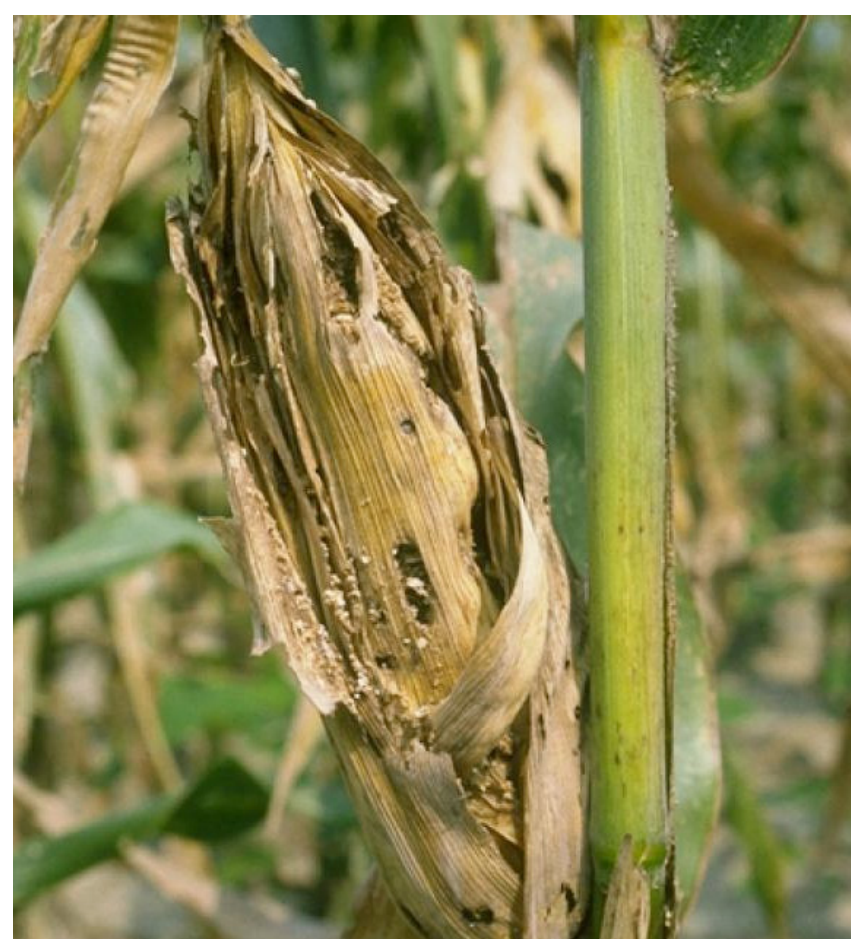

Spodoptera frugiperda, fall armyworm (Lepidoptera: Noctuidae) (a) Maize ear damaged by larvae; (b) larva and damage in whorl-stage maize.

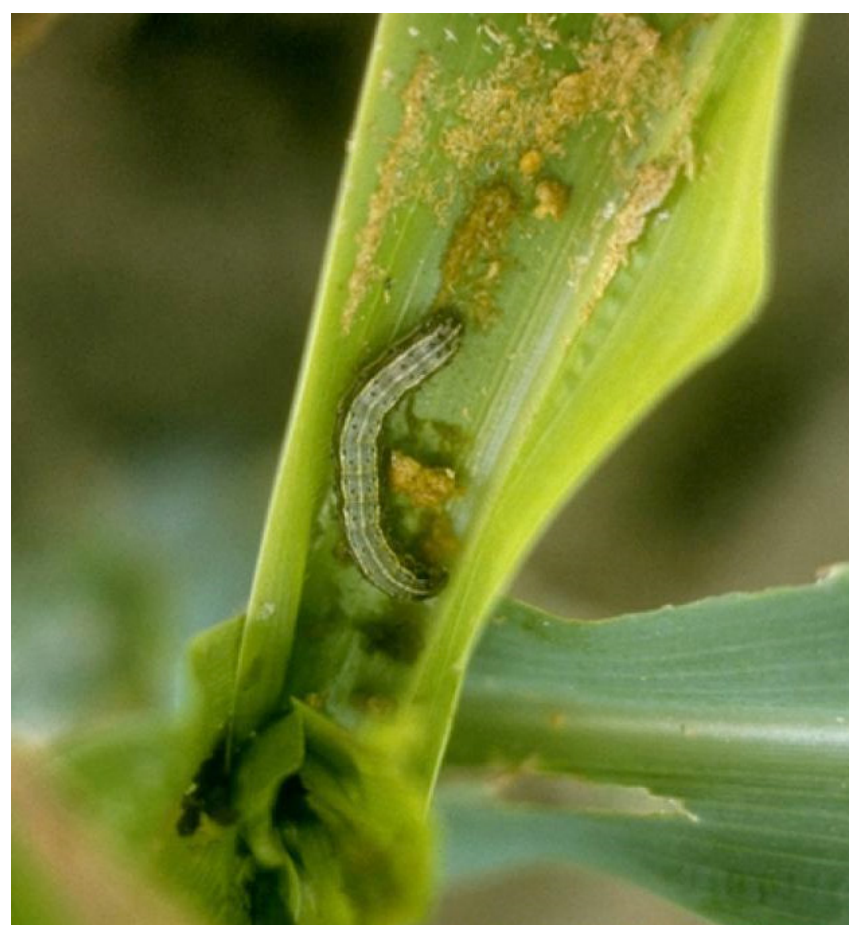

Source: EPPO (2020b); courtesy B.R. Wiseman, USDA/ARS, Tifton (United States of America). 


\section{Plant pathogens}

\section{Coffee leaf rust (Hemileia vastatrix) (Africa, Asia, Latin America)}

Coffee leaf rust, caused by Hemileia vastatrix, is one of the main factors limiting arabica coffee yield worldwide. Early and highly aggressive outbreaks of the disease have caused serious losses (up to 50-60 percent yield losses) in some Latin American countries, such as Colombia and Mexico, in the past few years.

Climate appears to play a role in the prevalence of the disease. One of the factors that promoted the occurrence of the rust epidemics in Central America was a reduction in the diurnal thermal amplitude, decreasing the latency period of the disease (Avelino etal., 2015). The shorter latency period promotes rapid increase of the pathogen population. Similarly, the pathogen's incubation period may be reduced with global warming. The analysis by Ghini etal. (2011) on future climate-change scenarios in Brazil indicated a trend of reduction in the incubation period of $H$. vastatrix, meaning that more generations of this pathogen could develop within a growing season. Consequently, the risk of coffee leaf rust epidemics might increase in the future, unless other factors change to mitigate disease risk, such as a reduced ability of the pathogen to infect coffee plants. Less cold winters can increase the amount of inoculum, in anticipation of pathogen infection (Avelino etal., 2015), but cold temperatures may not present a problem for the pathogen, considering that in Africa the displacement of coffee production to cooler and higher altitude regions has not limited the occurrence of coffee leaf rust because it was already widespread (Iscaro, 2014) and can adapt to different climates (Avelino etal., 2015). Thus, coffee leaf rust has been, and still is, one of the greatest challenges to global coffee production, and it will require the development of new strategies to guarantee its management, particularly if climate change affects the biology of the pathogen in the ways indicated by these studies.

\section{Banana Fusarium wilt (Fusarium oxysporum f. sp. cubense) TR4 (Australia, Mozambique, Colombia, Asia, Near East)}

The soil-borne fungus Fusarium oxysporum f. sp. cubense causes Fusarium wilt on banana. The planting of 'Cavendish', a resistant cultivar, was the solution found for the devastation caused by race 1 of the pathogen (Ploetz, 2005; Stover, 1986). However, a new strain of F. oxysporum, tropical race 4 (TR4), was found in 1990 in eastern Asia, parts of south-east Asia, and northern Australia, attacking 'Cavendish' clones in the tropics (Ploetz, 2005; Ploetz and Pegg, 2000). Since 2010, this race has spread to south and south-east Asian countries (India, the Lao People's Democratic Republic, Myanmar, Pakistan and Viet Nam), the Near East (Israel, Jordan, Lebanon and Oman), Africa (Mozambique) (Dita etal., 2018) and South America (Colombia) (García-Bastidas etal., 2019). This disease is a great threat to 'Cavendish' banana growers worldwide, irrespective of whether they farm on a large or small scale (Mostert etal., 2017). High temperatures, such as where temperatures rise from 24 to $34^{\circ} \mathrm{C}$, and extreme environmental events including cyclones and tropical storms, may increase the risk of the disease, particularly when 'Cavendish' banana plants suffer waterlogged soil (Pegg etal., 2019; Peng, Sivasithamparam and Turner, 1999). As there are still no banana cultivars resistant to TR4 and chemical control of the pathogen is not effective, preventive measures are the only option to manage the risk of Fusarium wilt disease 
(TR4). These include, for example, using disease-free 'Cavendish' banana planting material, detecting diseased plants early, and destroying diseased plants as soon as Fusarium wilt symptoms are observed (Pegg etal., 2019).

\section{Xylella fastidiosa (Americas, southern Europe, Near East)}

Xylella fastidiosa - a xylem-limited, Gram-negative bacterium - causes diseases on economically important crops, such as grapevine, citrus, olive, almond, peach and coffee, and in ornamental and forestry plants (Janse and Obradovic, 2010; Wells etal., 1987). It was reported in North and South America and Asia in the 1980s (Cornara etal., 2019). In 2013, X. fastidiosa subsp. pauca was reported on olive trees in southern Italy, causing severe losses and profoundly modifying the landscape typical of the local area by destroying centenary olive trees (Saponari etal., 2013). X. fastidiosa is transmitted by numerous species of sap-sucking hopper insects, including spittlebug and sharpshooter leafhoppers, mainly of the Aphrophoridae and Cicadellidae families (Almeida etal., 2005; Cornara etal., 2019).

Models of species bioclimatic distribution have shown that $X$. fastidiosa has the potential to expand beyond its current distribution and may reach other areas in Italy and elsewhere in Europe (Bosso etal. 2016; Godefroid etal., 2018). There are different subspecies identified for this bacterium, mainly fastidiosa, multiplex and pauca. According to the modelling predictions, the subspecies multiplex, and to a certain extent the subspecies fastidiosa, represent a threat to most of Europe, while the climatically suitable areas for the subspecies pauca are mostly limited to the Mediterranean countries (Godefroid etal., 2019). Through a predictive risk-ranking model, Frem etal. (2020) recently revealed that the Mediterranean basin, particularly Lebanon, runs the highest risk for establishment and spread of $X$. fastidiosa. Even though many Mediterranean countries are currently free of $X$. fastidiosa, in the near future they will be subject to a high risk of $X$. fastidiosa entry and establishment: Turkey is at the highest risk, followed by Greece, Morocco and Tunisia, which are ranked at highrisk level. Only three countries in the region (Bahrain, Libya and Yemen) are subject to the least risk level in terms of potential entry, establishment and spread of the bacterium. Notably, the problem is not limited to the Mediterranean. On the basis of disease symptoms and laboratory analysis, X. fastidiosa has been found associated with almond leaf scorch and Pierce's disease in grapevine in several provinces of the Islamic Republic of Iran (Amanifar etal., 2014), indicating that it will start to spread to neighbouring countries in the Near East.

Bosso etal. (2016) have predicted that climate change will not further increase the risk of $X$. fastidiosa in the future in most of the Mediterranean region, but the complete "host plant-vector-bacterium" relationship should also be considered when predicting future risk. Fortunately, vector performance is likely to suffer due to supra-optimal temperature and suboptimal humidity conditions, as recently simulated by Godefroid etal. (2020).

Management of $X$. fastidiosa will rely on the development of efficient strategies for integrated pest management, including improvements in detection of the pathogen and insect vectors, agricultural practices, and - last but not least - effective quarantine treatments to control the spread of the pathogen. 


\section{Oomycetes, including Phytophthora infestans and Plasmopara viticola (global)}

The potential displacement of oomycetes poleward because of climate change will present a challenge for plant protection, mainly in the northern hemisphere (Bebber, Ramotowski and Gurr, 2013). Phytophthora infestans, the oomycete that causes late blight in potato and tomato, has a great capacity to adapt to changing conditions, which is an important factor determining the risk of severe epidemics in the future. Indeed, several studies have suggested an increasing risk of $P$. infestans incidence in several countries (Hannukkala etal., 2007; Perez etal., 2010; Skelsey etal., 2016; Sparks etal., 2014), requiring the development of new strategies to control the disease and reduce its impact on food security, such as postponing the start of the potato growing season (Skelsey etal., 2016; Wu etal., 2020).

Studies in Egypt on the impact of climate change on tomato and potato late blight have shown how warmer winter weather affects their incidence and management (Fahim, Hassanein and Mostafa, 2003; Fahim etal., 2011). These have indicated that an epidemic of late blight on tomatoes occurring one to two weeks earlier would mean that two to three additional sprays would be needed to achieve sufficient control of the disease. Up to three additional fungicide sprays would therefore be needed each growing season in Egypt during the coming decades (2025-2100). As for potato late blight, caused by the same pathogen, comparison of weather conditions and disease occurrence in epidemic versus non-epidemic growing seasons has shown that wet and warm winter seasons promote potato late blight epidemics in Egypt. Favourable conditions in the winter allow a build-up of pathogen inoculum on early cultivars early in the growing season, leading to a tendency for the blight to appear in later-planted potato crops. It can therefore be expected that climate change will promote late blight epidemics in the future. However, there is a great need for further assessments of the impact of climate change on crop diseases in Egypt and other Near East countries (Fahim etal., 2011).

Downy mildew of grapevine, caused by the oomycete Plasmopara viticola, is another serious disease resulting in substantial production losses, varying from 5 percent yield losses up to 30-40 percent in most grape-growing regions. In the case of wine production, downy mildew also affects wine quality. As many of these regions have a temperate climate with temperatures that are suboptimal for the pathogen, an increase in air temperature will favour the occurrence of the disease. Studies considering future climate-change scenarios have therefore projected earlier disease outbreaks that require more treatments to control them (Angelotti etal., 2017; Salinari etal., 2006, 2007). Short-term studies carried out in phytotrons have also confirmed an increased severity of grape downy mildew under simulated climate-change conditions (Pugliese, Gullino and Garibaldi, 2010).

\section{Fungi producing mycotoxins (global)}

In general, climate change is expected to result in an increased presence of mycotoxins in crops, but the complexity of the fungal flora associated with each crop and its interaction with the environment means that it is difficult to draw conclusions without conducting specific studies. Nevertheless, there are many results available. For instance, the work carried out by Battilani etal. (2016) indicates that global warming could extend the northern limit of aflatoxin risk in maize in Europe, and Van 
der Fels-Klerx, Liu and Battilani (2016) have made quantitative estimations of the impacts of climate change on mycotoxin occurrence. Medina etal. (2017) reviewed the impacts of climate change on mycotoxigenic fungi, examining the impacts of the three-way interactions between elevated $\mathrm{CO}_{2}$ (350-400 vs 650-1200 ppm), temperature increases $\left(+2-5^{\circ} \mathrm{C}\right)$ and drought stress on growth and mycotoxin production by key spoilage fungi in cereals and nuts, including Alternaria, Aspergillus, Fusarium and Penicillium species. The growth of Aspergillus flavus, responsible for producing aflatoxin B1, appears to be unaffected by simulated climate-change scenarios. However, a significant stimulation of aflatoxin B1 production has been found both in vitro and in vivo in maize. In contrast, the behaviour of other Aspergillus species, responsible for ochratoxin A contamination of a range of commodities, and Fusarium verticillioides, producing fumonisins, suggests that some species are more resilient to climate change than others, especially in terms of mycotoxin production.

In addition to the effects of climate change on these commonly occurring fungi, climate change could also influence the mycotoxin production of emerging pathogens, such as the increases shown experimentally by Siciliano etal. (2017a, 2017b) in Alternaria and Myrothecium species. Furthermore, acclimatization of mycotoxigenic fungal pathogens to climate-change factors may result in increased disease and perhaps mycotoxin contamination of staple cereals as well as other crops. Thus, managing mycotoxin risks will remain a great challenge in the future (Juroszek and von Tiedemann, 2013b) as climate change could worsen the situation (Miedaner and Juroszek, 2021b).

\section{Nematodes}

\section{Citrus lesion nematode (Pratylenchus coffeae) (global)}

The citrus lesion nematode, Pratylenchus coffeae, is widely distributed in citrus orchards worldwide. It mainly infests the plant via the feeder roots, where motile stages of the pest penetrate the cortical tissue. The vascular tissue remains intact until invaded by other organisms in a secondary infection (Duncan, 2009). The nematode is known to reduce citrus root weights by as much as half, and experimental inoculation of young trees has shown growth reductions ranging from 49 to 80 percent, with a three- to 20 -fold reduction in the numbers of fruits (O'Bannon and Tomerlin, 1973). Recent studies on current climate change in Egypt indicate that higher temperatures may aggravate the damage caused by the citrus lesion nematode to the citrus root system, because the nematode's reproduction rate is highest when soil temperatures are relatively high $\left(26-30^{\circ} \mathrm{C}\right.$ ) (Abd-Elgawad, 2020). At such temperatures, the life cycle is completed in less than one month and the pathogen may reach density levels as high as 10000 nematodes/g root; the nematode can also survive in roots in the soil for at least four months. Unfortunately, however, commercial rootstocks resistant to this nematode are not available yet (Abd-Elgawad, 2020).

\section{Soybean cyst nematode (Heterodera glycines) (global)}

The soybean cyst nematode (Heterodera glycines) is the most economically damaging pathogen of soybean (Glycine max) in the United States of America and Canada (Tylka and Marett, 2014). It also causes considerable yield losses in many other major soybean-producing countries, such as Argentina, Brazil and China. Thus, its potential for causing serious worldwide yield loss is high. 
Global warming is likely to promote the northward (northern hemisphere) and southward (southern hemisphere) expansion of the nematode's geographical range, and increase the number of nematode generations per soybean crop-growing season (St-Marseille etal., 2019) until supra-optimal temperature conditions for the nematode are reached.

To manage the pest, the most important strategies are the use of resistant cultivars (Shaibu etal., 2020) and crop rotation (Niblack, 2005). According to Niblack (2005), rotation includes at least three different aspects: ideally, cultivating soybean only once every five years in any one field (although the benefit of crop rotation may be less if weeds are present that can act as alternative hosts of the pest); using non-host crop plants, including cover or catch crops in a wide crop rotation; and planting different resistant or tolerant soybean cultivars in different years in the same field, in order to minimize the adaptation potential of the nematode populations.

\section{Pine wilt nematode (Bursaphelenchus xylophilus) (North America and eastern Asia)}

According to Jones etal. (2013), the pine wilt nematode, B. xylophilus, is native to North America, where it infests pine trees (Pinus species) but does not seriously damage them. However, in its non-native environment, including Asia (China, Republic of Korea, Japan and others) and Europe (a few occurrences in Portugal and Spain), it is a serious pest, killing millions of pine trees. The nematode is vectored by the adult stage of Monochamus beetles, which fly among pine trees and across longer distances. It is expected that pine wilt disease will be increasingly favoured by global warming because Monochamus beetles, like many other forest insects (Seidl etal., 2017), will benefit from increasing temperatures, particularly in temperate regions (Ikegami and Jenkins, 2018). A number of risk assessments carried out demonstrate that with increasing temperatures in temperate regions the mortality of conifers will increase. In the Mediterranean area, which is the most endangered area in Europe, high mortality of coniferous trees would have serious environmental consequences.

\section{Weeds}

\section{Butterfly bush (Buddleja davidii) (global)}

The geographical range of the invasive weed Buddleja davidii in Europe, North America and New Zealand is projected to expand by the end of the twenty-first century as growth limitations due to cold stress are reduced (Kriticos etal., 2011). In contrast, the range of this weed in Africa, Asia, South America, and Australia is projected to contract because of increased heat stress. Overall, the total area of land with suitable growing conditions for the weed is projected to decrease by 11 percent on average (8, 10 or 16 percent, dependent on the climate-change scenario used). Possible adaptation strategies include the identification of areas of increasing and decreasing invasion threat, so that management resources can be allocated appropriately to reduce further spread of the weed (Kriticos etal., 2011). 


\section{Serrated tussock grass (Nassella trichotoma) (global)}

Under current climate conditions, the grass weed Nassella trichotoma has considerable potential to spread. In future, opportunities to invade new areas that are suitable will continue, but by the end of the twenty-first century, it is projected that the total area suitable will have decreased globally between 20 and 27 percent (depending on the climate-change scenario used), mostly as a result of a projected increase in heat stress (Watt etal., 2011). Possible management strategies include identifying high-risk areas of invasion, applying measures to reduce human-assisted dispersal of seeds, and applying weed-control measures to reduce the wind-borne dispersal of seeds (Watt etal., 2011). 


\section{Prevention, \\ mitigation and adaptation}

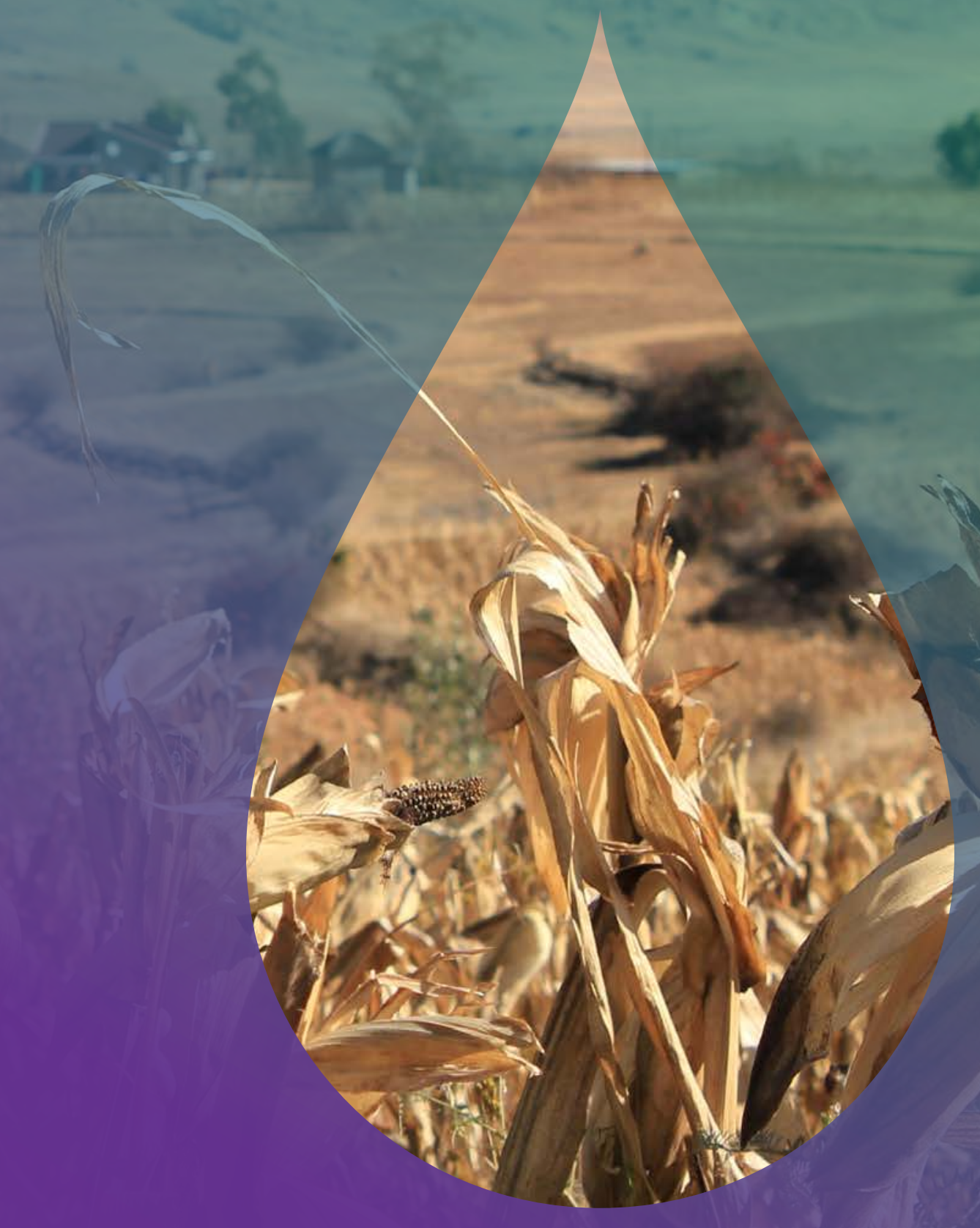




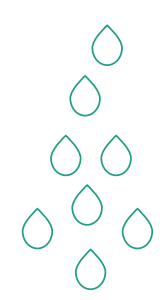

$\mathbf{T}$

he focus in this section is to review the measures that can be taken to prevent, mitigate and adapt to the potential effects of climate change on pests and hence on plant health. Since interdependencies between plant ecosystems exist, information on pest species and other species (e.g. beneficial or with no known economic effect) in agriculture, horticulture, forestry and unmanaged habitats are included, for two main reasons (Juroszek and von Tiedemann, 2013a). First, an interdisciplinary approach to the management of pests and diseases should be established, because the knowledge gained in different disciplines can complement each other and should, therefore, be exchanged and used across disciplines (Jactel etal., 2020; Wilkinson etal., 2011). Second, many pest species, especially mobile generalists and those not restricted to a certain habitat, live in both managed and unmanaged ecosystems. Interdisciplinary approaches are particularly important if pest species change their host range when crossing between unmanaged and managed ecosystems, resulting in new emerging pest species in a crop or vice versa (Jones, 2016).

\section{Preventive measures}

The most effective way to prevent and limit the international spread of pests through trade and passenger movements is to regulate their movement through phytosanitary measures, and ensure that best agricultural practices are applied to reduce the incidence of pests to a low level.

\section{The regulatory aspects}

According to Carvajal-Yepes etal. (2019) and Giovani etal. (2020), phytosanitary import legislation is the first line of defence in any prevention of international spread. The objective of a phytosanitary import regulatory system is to prevent or limit the introduction of regulated pests with imported commodities and other regulated articles and passengers. A phytosanitary import regulatory system usually consists of two components: a regulatory framework of phytosanitary legislation, regulations and procedures; and an official service, the national plant protection organization (NPPO), responsible for operation or oversight of the system (ISPM 20, 2019). The NPPO has a number of responsibilities in operating a phytosanitary import regulatory system, including certain responsibilities identified in Article IV.2 of the IPPC (IPPC Secretariat, 1997). In relation to imports these include, but are not limited to, surveillance, inspection, the conduct of PRA, and the training and development of staff.

For a phytosanitary import regulatory system to remain effective in a situation of climate change, it will be all the more important to have good risk assessment capabilities and to employ them to assess potential risk scenarios, taking climate change into account. The implementation of functioning and well-organized surveillance and monitoring activities will also be crucial. Official services will need to survey and monitor with more vigilance in order to detect promptly both new introductions (including those establishing because of changing climatic parameters) and changes in pest status and to be able to react quickly (Carvajal-Yepes etal., 2019; Lopian, 2018; Giovani etal., 2020; STDF/World Bank, 2011). 
The cornerstone of any efficient phytosanitary import regulatory system is the availability of a PRA conducted by an NPPO. Pest risk analysis provides the NPPO with the rationale for phytosanitary measures to prevent the introduction of pests, by evaluating scientific evidence to determine whether an organism is a pest (ISPM 2, 2019). Pest risk analysis evaluates the probability of introduction and spread of the pest and the magnitude of its potential economic consequences in a defined area by using biological or other scientific and economic evidence. It may identify potential management options that can reduce the risk to an acceptable level. In addition, it can be used to establish phytosanitary regulations. Pest risk analysis also considers commodities and the risks associated with them from a particular area of origin. A suite of specific PRA standards to be used by countries in different situations have been developed under the auspices of the IPPC Secretariat. ${ }^{3}$

As climate change has an effect on the biology and epidemiology of pests, PRA activities will need to be intensified at national, regional and international levels and climate-change aspects will need to be incorporated into the assessment of planthealth risks (Lopian, 2018). The introduction and spread of serious invasive pests can only be prevented if NPPOs are aware of the risks and this awareness is primarily the result of a PRA. In this context, it is important to ensure that climate-change impacts are appropriately reflected in the PRA methodology and process to allow risk assessors to correctly analyse risks and to suggest mitigation measures.

\section{Surveillance and monitoring}

One of the most essential activities of NPPOs is surveillance and monitoring for pests, which allows them to detect newly introduced pests early and consequently take immediate control and eradication actions. Usually, the earlier a pest is detected after introduction, the better are the chances that eradication measures will be successful. Accordingly, one of the major components of a strategy to address the dangers of pest introduction in a changing climatic context must be surveillance and monitoring (FAO, 2008) in order to allow the detection of new pest introductions. It is therefore not surprising that much of the work developed under the auspices of the IPPC Secretariat has focused on surveillance and detection, including an ISPM (ISPM 6, 2018) and a manual on surveillance (IPPC Secretariat, 2016), together with a suite of diagnostic protocols for detecting and identifying pests and diseases.

Climatic variability caused by climate change will have considerable effects on the design and implementation of appropriate surveillance and monitoring programmes carried out by official services. According to ISPM 6 (Surveillance), the suitability of the climate and other ecological conditions in the area for the pest is one of the factors that may determine the sites selected for surveillance. Yet there are still considerable unknowns regarding the suitability of specific climatic conditions for individual species.

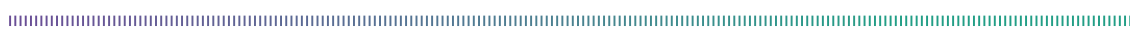

3 See all IPPC adopted International Standards for Phytosanitary Measures at https://www.ippc.int/ en/core-activities/standards-setting/ispms/
} 
The effects of climate change on the distribution of species are not yet well understood, and the effects of climate change on microclimates and their species is currently under discussion and investigation. While it is suggested that microclimates can function as buffers to species extinction by creating so-called "microrefugia" (Suggitt etal., 2018), it is also acknowledged that knowledge about the effects of climate change on microclimates and their ecology is still too scarce and that more research is necessary to more accurately estimate the future climatic conditions experienced by organisms in microclimates (Maclean, 2020). Future surveillance and monitoring programmes will need to take account of the results from such research. Surveillance activities, however, may not only be limited to official surveys. The possibility to utilize "citizen science" for the detection of emerging plant-health threats is a promising tool and should be further considered.

\section{International cooperation and information exchange}

Climate change will shift agro-climatic zones (King etal., 2018). This shift may lead to new trade flows, providing agricultural products to countries that suffer most from the shortage of them. In cases where crop production for specific species shifts as a result of climatically changed conditions, trade routes for these species will also change (Lopian, 2018). Exacerbating the above, the IPCC predicts that climate change will result in increased international agricultural trade in terms of both physical volume and commercial value (IPCC, 2014b).

The shift of agricultural production zones, changed trade flows and the consequent increase of international agricultural trade volumes will, in combination with the limited knowledge of pest behaviour under new climatic and ecosystem conditions, result in a deficiency of reliable, scientifically verifiable information upon which risk assessors and regulators can base their assessments and mitigation measures. This deficiency could be alleviated through the establishment of a reliable international information-exchange network dedicated to providing official services with information about the occurrence of pests and potential pathways. However, although the IPPC Secretariat does have an information-exchange mandate, the information-exchange activities undertaken are extremely limited and are more of a passive nature, publishing reports made by contracting parties. Much still needs to be done, therefore, to enhance the international exchange of information.

\section{Preventive pest-management practices}

Best-available practices for pest management include, for example, production of clean seed and planting material, early warning systems, good diagnostic tools, and effective treatments such as seed dressings (Gullino, Gilardi and Garibaldi, 2014b; Gullino and Munkvold, 2014; Munkvold, 2009; Munkvold and Gullino, 2020; Thomas etal., 2017), together with the associated sampling and monitoring. Other best-available practices include the use of resistant cultivars when available, the adoption of cultural practices promoting plant health, integrated pest-management systems, the application of rigorous hygiene measures, and the use of biological crop-protection products. These practices will become all the more important in the face of increasing and changing threats from pests due to climate change, and some adjustments are likely to be needed to maintain their effectiveness: for example, crop rotation may involve species better adapted to local climatic conditions and the application regime for fungicides may need to be intensified (see Table 4). 
Table 4. Examples of some assumptions about the potential influence of changing atmospheric composition and climate on selected plant-disease management strategies or tools

\begin{tabular}{|c|c|c|c|}
\hline $\begin{array}{l}\text { CONTROL } \\
\text { STRATEGY }\end{array}$ & TOOL & EXPECTED EFFECTS OF CHANGED CLIMATE & POTENTIAL OF TOOL FOR ADAPTATION \\
\hline Avoidance & $\begin{array}{l}\text { Barrier to entry } \\
\text { (quarantine) }\end{array}$ & $\begin{array}{l}\text { Climate-mediated change in pathogen dispersal - } \\
\text { frequency, abundance, distance, speed. }\end{array}$ & $\begin{array}{l}\text { Altered efficacy of quarantine practices likely. } \\
\text { New phytosanitary measures, including the use } \\
\text { of international (IPPC) standard treatments, will } \\
\text { be needed. }\end{array}$ \\
\hline Preventive & Crop rotation & $\begin{array}{l}\text { No direct effect; diversity in cropping systems will } \\
\text { remain important to reduce risk of disease. }\end{array}$ & $\begin{array}{l}\text { Crop species better adapted to local climatic } \\
\text { conditions are possibly required. }\end{array}$ \\
\hline Preventive & $\begin{array}{l}\text { Plant residue } \\
\text { management }\end{array}$ & $\begin{array}{l}\text { Potential increase in crop biomass through the } \\
\mathrm{CO}_{2} \text { fertilizing effect, unless high temperature and } \\
\text { drought counterbalance the fertilizing effect. }\end{array}$ & $\begin{array}{l}\text { Innovative approaches needed to reduce } \\
\text { inoculum level and saprophytic colonization. }\end{array}$ \\
\hline Preventive & Sowing or planting date & $\begin{array}{l}\text { Adjustments likely to be necessary; simple and } \\
\text { cheap method to escape biotic and abiotic stress; } \\
\text { however, disadvantages also possible. }\end{array}$ & $\begin{array}{l}\text { Appears to be a powerful tool (often mentioned in } \\
\text { the literature). }\end{array}$ \\
\hline Preventive & Host plant resistance & $\begin{array}{l}\text { Temperature dependent resistance may be } \\
\text { overcome by pathogens; changes in plant } \\
\text { morphology and physiology may affect resistance; } \\
\text { potentially accelerated pathogen evolution may } \\
\text { erode disease resistance prematurely. }\end{array}$ & $\begin{array}{l}\text { Altered efficacy of host-plant resistance likely } \\
\text { (higher, same, and lower efficacy depending on } \\
\text { resistance (R) gene, pathogen population, etc.). }\end{array}$ \\
\hline Preventive & $\begin{array}{l}\text { Cleaning machinery } \\
\text { and tools }\end{array}$ & Presumably no major effects. & Phytosanitary methods will remain important. \\
\hline Preventive & $\begin{array}{l}\text { Use of healthy seeds } \\
\text { and plantlets }\end{array}$ & Presumably no major effects. & Preventive methods will remain important. \\
\hline Preventive & $\begin{array}{l}\text { Input levels } \\
\text { (e.g. amount of } \\
\text { irrigation) }\end{array}$ & $\begin{array}{l}\text { Presumably higher temperatures will result in } \\
\text { increased irrigation of more crops and in more } \\
\text { regions. }\end{array}$ & $\begin{array}{l}\text { Water conservation may demand efficient } \\
\text { technologies such as drip irrigation, thereby } \\
\text { reducing risk of foliar diseases. }\end{array}$ \\
\hline $\begin{array}{l}\text { Preventive or } \\
\text { curative }\end{array}$ & $\begin{array}{l}\text { Field monitoring and } \\
\text { use of decision-support } \\
\text { systems }\end{array}$ & Presumably no major effects. & $\begin{array}{l}\text { Field monitoring and decision-support systems } \\
\text { will remain or become more important. }\end{array}$ \\
\hline $\begin{array}{l}\text { Preventive or } \\
\text { curative }\end{array}$ & $\begin{array}{l}\text { Soil solarization } \\
\text { (covering soil, usually } \\
\text { with a plastic sheet, } \\
\text { to trap solar energy in } \\
\text { order to reduce pests in } \\
\text { the soil) }\end{array}$ & $\begin{array}{l}\text { Global warming may facilitate the use of this tool } \\
\text { (it may be effective in more plant-pathogen systems } \\
\text { and regions, heat may reach deeper soil layers, and } \\
\text { duration of mulching period may be shorter). }\end{array}$ & $\begin{array}{l}\text { Altered efficacy likely, but generally positive } \\
\text { effects. }\end{array}$ \\
\hline $\begin{array}{l}\text { Preventive or } \\
\text { curative }\end{array}$ & $\begin{array}{l}\text { Antagonists, biological } \\
\text { control agents }\end{array}$ & $\begin{array}{l}\text { Presumably, vulnerability of biological control } \\
\text { agents will be higher due to climate variability. }\end{array}$ & $\begin{array}{l}\text { Altered efficacy likely (higher, same or } \\
\text { lower, dependent on product, environment, } \\
\text { management, etc.). }\end{array}$ \\
\hline $\begin{array}{l}\text { Preventive or } \\
\text { curative }\end{array}$ & Contact fungicides & $\begin{array}{l}\text { If rainfall occurs more frequently, more applications } \\
\text { may be triggered; faster or slower crop growth may } \\
\text { shorten or lengthen the time between applications. }\end{array}$ & $\begin{array}{l}\text { Altered efficacy likely (higher, same or } \\
\text { lower, dependent on product, environment, } \\
\text { management, etc.). }\end{array}$ \\
\hline $\begin{array}{l}\text { Preventive or } \\
\text { curative }\end{array}$ & Systemic fungicides & $\begin{array}{l}\text { More knowledge on foliar uptake process of } \\
\text { systemic fungicides must be gained to make } \\
\text { reliable predictions. Nevertheless, it is possible that } \\
\text { with increasing temperature fungicide efficacy will } \\
\text { be reduced, simply because pathogen growth will } \\
\text { be stronger. }\end{array}$ & $\begin{array}{l}\text { Altered efficacy likely (higher, same or } \\
\text { lower, dependent on product, environment, } \\
\text { management, etc.). }\end{array}$ \\
\hline
\end{tabular}




\section{Recent technological developments}

In the following paragraphs, one promising advance in technology - the use of nanotechnology - is highlighted as an example of how new technologies can be harnessed to protect plant health. Nanotechnology provides tools for innovative and improved crop-protection products to address increasing pest risk, including that due to climate change. It is still under development and not yet widely applied in practice. It may also not be easily available in low-income countries, at least not immediately, for economic reasons. But it illustrates what is potentially possible. Improving such tools is very important and will be crucial in the future.

\section{Nanofertilizers and pesticides}

Over the past two decades, advances in nanoscale science have driven new interest and research into the applications and implications of nanotechnology for sustainable agriculture (Scott, Chen and Cui, 2018). In addition to the foundational use of nanofertilizers for precision agriculture (Raliya etal., 2018), it has been suggested that nanotechnology may potentially improve the efficacy and safety of pesticides. The nanotechnology-produced pesticides would have a large surface area and be capable of precision delivery in response to environmental triggers such as temperature, pH, humidity, enzymes and light (Bingna etal., 2018), as well as being soluble in water, thereby minimizing environmental residues (Zhao etal., 2018). Early experiments with solid nanoparticles consisting of metal oxides, sulphur and silica proved successful in controlling a range of pests (Goswami etal., 2010).

More recently, nanotechnology applications in the agricultural domain typically consist of the encapsulation of known herbicides, fungicides or insecticides into synthetic nanocarriers composed of clays, silica, lignin or natural polymers, including alginate, chitosan and ethyl cellulose (Diyanat etal., 2019). Polycaprolactone has been used as a nanocarrier for the herbicide pretilachlor (Diyanat etal., 2019), the triazine herbicides atrazine, ametryn and simazine (Grillo etal., 2012), and the pesticide avermectin (Su etal., 2020). Polycaprolactone has become popular because it naturally degrades in the environment, is inexpensive to produce and is not reliant upon petroleum plastic production (Sabry and Ragaei, 2018).

Nanopesticides have been very successfully tested for control of pine wilt nematode, with nanoencapsulated avermectin shown to have superior toxicity to the nematode's gastrointestinal system, greater sustained-release performance and improved photolytic stability in comparison to a traditional delivery of avermectin (Su etal., 2020). Nanoencapsulating atrazine has also been found to reduce the harmful environmental effects of this herbicide, without negatively affecting the mortality rate of Bidens pilosa seedlings (Preisler etal., 2020). Nanoencapsulated atrazine in the latter study had inhibitory effects at $200 \mathrm{~g} / \mathrm{h}$ a that were equivalent to those of nonencapsulated herbicide at $2000 \mathrm{~g} / \mathrm{ha}$, representing a ten-fold reduction in the herbicide concentration. Also, in the case of mustard plants, polycaprolactone-encapsulated atrazine at a ten-fold dilution has been found to be as effective as non-diluted, nonencapsulated atrazine (Oliveira etal., 2015). 


\section{Enhanced breeding for resistance}

Another opportunity for the use of nanotechnology in agriculture is as a delivery method for DNA transfer in plants to promote resistance to pests (Rai and Ingle, 2012; Sabry and Ragaei, 2018), thereby reducing the use of potentially environmentally harmful chemical pesticides. It has been proposed that nanoparticles could be used to passively deliver nuclease-based genome editing payloads as a method of plant genetic engineering. This method would overcome challenges to current gene transfer methods (such as gene-gun and ultrasound) caused by the physical barrier of a multi-layered and rigid plant cell wall that has caused progress in plant genetic engineering to lag behind that in animal systems (Cunningham etal., 2018). Some techniques for delivering DNA into animal cells can be adapted to plants under controlled conditions (Chang etal., 2013; Torney etal., 2007).

\section{Information sharing framework}

To complement the development of advanced technologies such as those described above, there are also initiatives to promote the sharing of data and information. The MyPestGuide initiative in Australia, for example, incorporates weed reporting, field guides for pest identification, and decision management tools in a shared platform (Wright etal., 2018). A global framework for data sharing could help efforts to tackle fast-spreading and potentially high-impact pests (Carvajal-Yepes etal., 2019). 


\section{Mitigation and adaptation}

With very few exceptions (e.g. Gouache etal., 2011), pest risk simulations have not included options that farmers and growers might take to mitigate for, or adapt to, an increased future pest risk. This is true for agriculture (Juroszek and von Tiedemann, 2015) and forestry (Bentz and Jönsson, 2015). Nevertheless, in agriculture there are a range of potential short-term mitigation and adaptation options available and these should be considered, not only by farmers and growers but also for inclusion in simulation models to support future decision-making. Further development of tools required for adaptive management of pests will increase the probability of successful adaptation strategies in the future (Macfayden, McDonald and Hill, 2018).

Improved host-plant resistance (and competitiveness of crop plants to weeds) and adjustments to pesticide application are considered by most scientists to be the two most effective ways of adapting crop protection to future climatic conditions (reviewed by Juroszek and von Tiedemann, 2015). Other options include adjustments to sowing time, longer crop rotation, improved pest forecasting, adjustment of agronomic practices such as irrigation and fertilization, and provision of targeted advice (Juroszek and von Tiedemann, 2015). Interestingly, several other potential adaptation tools in crop protection, such as modification of the microclimate by altering sowing density, are not discussed at all in the literature related to pest risk simulations.

In forestry and agriculture, climate-smart strategies for pest management may also need to be adopted (Heeb, Jenner and Cook, 2019; Lipper etal., 2014). In general, integrated pest management includes a wide range of direct and indirect plant-health management measures (Heeb, Jenner and Cock, 2019; Juroszek and von Tiedemann, 2011). These include quarantine (biosecurity), other phytosanitary measures (e.g. healthy seeds and seedlings), careful monitoring and optimal timing of needed interventions (Heeb, Jenner and Cook, 2019; Strand, 2000) or biological control (Eigenbrode, Davis and Crowder, 2015).

In the context of adapting cropping systems to climate change, breeding for disease resistance is one of the most attractive options (Miedaner and Juroszek, 2021a, 2021b). Varieties with tolerance to drought, high temperatures, and pests are crucial for food security in staple crops such as maize and beans as well as for cash crops for export, such as coffee and soybeans. Sometimes, new varieties allow adjustments in farming systems in order to moderate the pest risk associated with likely changes. For example, the availability of new wheat varieties permits wheat crops in central Queensland (Australia) to be planted three to four weeks earlier (Howden, Gifford and Meinke, 2010). Also, in the case of cocoa, a multi-criteria selection in developing new varieties is suggested in the context of climate change (Cilas and Bastide, 2020). Although crop breeding, and especially tree breeding, has a long lag time in response to new challenges, models of climate-change effects on pest risk can help to inform strategies in advance of new problems. The identification, conservation and use of ancient varieties can also be useful. 
In forestry, adaption to respond to potential climate-change effects is most likely to involve preventive measures, such as removing infested trees to avoid further spread of pests, because of the difficulties in effectively managing tall adult trees (Bonello etal., 2020; Liebhold and Kean, 2019). Another major preventive adaptation option is the exploitation of genetic diversity: the choice of suitable tree species, or pest-resistant or tolerant clones or cultivars if available, when new forests are planted (Bonello etal., 2020).

The choice of adaptation strategies will depend on many factors. Cost is one factor, with Srivastava, Kumar and Aggarwal (2010) concluding that more low-cost adaptation strategies, such as changing the sowing date and choice of cultivar, should be explored to reduce the vulnerability of crop production to climate change. The practicality of changing planting or harvesting dates, however, is dependent on the potential yield penalty and on the location where the crop is grown, the cultivar preferences of farmers and consumers, and the market situation (Wolfe etal., 2008). More expensive adaptation options may also be needed (Juroszek and von Tiedemann, 2011). This may involve, for instance, the development of more powerful methods to manage pathogens in crop residues, which could be combined with already well-established methods such as crop rotation in order to avoid saprophytic colonization of crop residues by pathogens and to decrease the carry-over of inoculum between cropping seasons (Melloy etal., 2010). "Old-fashioned" methods such as turning the soil can also be a powerful way to manage diseased crop residues (Miedaner and Juroszek, 2021b), although conservation agriculture might be better suited in drought-prone areas. Ploughing the soil also entails more fuel input and hence more climate-relevant $\mathrm{CO}_{2}$ emissions compared to minimum tillage.

Finally, considering strategic planning, it is important to decide where to grow perennial agricultural crops such as date palms (Shabani and Kumar, 2013). With knowledge about where economically important crop diseases of such crops might occur in the future, low-risk locations could be identified in order to avoid or minimize the future impact of these diseases (Shabani and Kumar, 2013). This applies also to forestry, where planning is particularly important to avoid or minimize future increasing pest risks, as explained above. For annual crops such as oilseed rape, shifting of cultivation zones has been suggested as one of the adaptations under a worse-case scenario (Butterworth etal., 2010). Indeed, in Egypt, faba bean cultivation has been shifted from central Egypt to the cooler Nile Delta region in the north to escape the detrimental impacts of viral disease, possibly caused - at least in part - by global warming.

All of the options highlighted above may have a role to play in allowing farmers and growers to mitigate for, and adapt to, an increased pest risk. In general, however, it will be important to favour and implement those technologies and practices that are able to simultaneously contribute to increased productivity and reduced vulnerability to the changes brought about by climate-relevant emissions including $\mathrm{CO}_{2}$, $\mathrm{N}_{2} \mathrm{O}$ and $\mathrm{CH}_{4}$. 
Results and

recommendations 


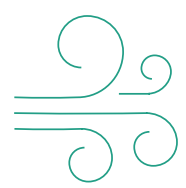

I

recent decades, there has been an explosion in the volume of research on

climate-change biology, resulting in many publications each year, particularly

over the past ten years (e.g. Björkman and Niemelä, 2015; Juroszek et al., 2020; Peterson, Menon and Li, 2010). Most studies (summarized in Table 5) indicate that, in general, the pest risk from insects, pathogens and weeds will increase in agricultural ecosystems under climate-change scenarios (Choudhary, Kumari and Fand, 2019; Clements, DiTommaso and Hyvönen, 2014; Juroszek etal., 2020), especially in today's cooler Arctic, boreal, temperate and subtropical regions. Evidence suggests that all climates will be impacted but that the nature and extent of the impact will vary with the ability of production systems and natural ecosystems to adapt and evolve. This is also mostly true for pathogens and insect pests in forestry (Seidl et al., 2017).

Climate-smart strategies for controlling pests were recently outlined by Heeb, Jenner and Cook (2019). These and other preventive and curative plant-protection measures will be needed for countries to adapt to a new climate scenario (Almekinders etal., 2019; Erikson and Griffin, 2014; Thomas-Sharma etal., 2016). But consideration will also need to be given to regulatory arrangements, research needs, international cooperation and capacity building, and recommendations on these aspects are outlined in this section of the report.

\section{Policy making and regulatory issues}

\section{Adjusting pest risk analysis with regard to climate change}

Pest risk analysis provides the scientific justification for all phytosanitary measures, including those developed under the auspices of the IPPC Secretariat. It is suggested that ISPMs relevant to PRA are assessed with regard to their suitability to address issues related to climate change. Pest risk analysis activities need to be intensified at national, regional and international levels and climate-change aspects need to be included in the assessment of pest risk.

\section{Surveillance and monitoring relevant to climate change}

Surveillance and monitoring are important tools to detect the introduction of new pests or to monitor their status. It is suggested that ISPMs and guidance on these topics developed under the auspices of the IPPC Secretariat are assessed to determine whether they need revising to take account of the effects of climate change. National, regional and international surveillance and monitoring activities for planthealth threats should be intensified. It is suggested that consideration be given to the development of model templates for multilateral surveillance programmes, especially for developing countries, to demonstrate how such programmes may be set up to offset phytosanitary threats. 
The international exchange of information on trade flows, pest occurrences and pest interceptions is extremely important to offset the paucity of information generated by scientific research with regard to the impacts of climate change on plant health. It is also critical that information on changes to pest distributions, host range, and adaptability of pests and host plants are shared. It is necessary to enhance the IPPC reporting system, which combines official reporting by contracting parties with other available and published information.

\section{Research required}

Prominent research gaps related to climate change and pests are listed in Table 6. Funding bodies and organizations conducting research should consider these research gaps, where possible, for inclusion in their research programmes. In particular, in most geographical areas greater attention needs to be paid to sustaining comprehensive and multidisciplinary research programmes. Research programmes should cover the need of industrialized as well as developing countries. A long-term financial commitment will be required in order to capture the long-term effects of ongoing and future climate change and related pest risk, including testing methods to minimize risk. For this reason, a few "hot spots" (climate-sensitive production areas) should be selected for implementation of long-term research and development activities ("Climate Change Demonstration Sites for Pest Risk Analysis and testing Pest Risk Reduction Methods", CCDS-PRA-PRRM).

In addition, investment by national governments should be directed to strengthening national surveillance systems and structures, such as diagnostic laboratories, in order to be able to rapidly counteract possible biological invasions. Moreover, well-functioning PRA units should be put in place, in order to be able to prevent them.

Some specific issues requiring research are highlighted below.

\section{Studies on the effect of climate change on plant-protection products and on management strategies}

There are many research gaps that need to be filled in this field. It is possible, for example, that pests may become resistant to plant-protection products if the usage of such products becomes more frequent in response to increased pest prevalence due to climate change. However, research is needed to explore this. Furthermore, the direct effect of climate change on the effectiveness of the management strategies adopted, particularly on chemical or biological control measures, has not been studied enough up to now (Gilardi etal., 2017, Gullino etal., 2020) and should be much more extensively investigated (Table 6). Results from a few experiments are already available, for instance suggesting that global warming may increase the risk of herbicide-resistant weeds because of enhanced temperature-dependent detoxification of the herbicide by the weed (Matzrafi etal., 2016). Research is also needed on below-ground pests, as most research related to potential climate-change effects on pests has disproportionately focused on above-rather than below-ground pests, despite the importance of the latter pests on below-ground processes and their influence on soil health (Chakraborty, Pangga and Roper, 2012; Pritchard, 2011). 
Table 5. Examples of recent review articles focusing on climate change and future pest risk for plant ecosystems in agriculture, horticulture, forestry, and unmanaged natural habitats

PEST GROUP

REFERENCES (CHRONOLOGICAL ORDER WITHIN EACH GROUP)

Insects

Choudhary, Kumari and Fand, 2019; Jactel, Koricheva and Castagneyrol, 2019; Kellermann and van Heerwaarden, 2019; Moriyama and Numata, 2019; Yadav, Stow and Dudaniec, 2019; Borkataki et al., 2020; Debelo, 2020; Frank, 2020; Lehmann etal., 2020; Marshall, Gotthard and Williams, 2020.

\begin{tabular}{ll}
\hline & Pebelo, 2020; Frank, 2020; Lehmann etal., 2020; Marshall, Gotthard and Williams, 2020. \\
\hline \multirow{2}{*}{ Pathogens } & Singh, 2019; Castillo etal., 2020; Garrett et al. (2020a); Hunjan and Lore, 2020; Juroszek et al. 2020; Kumar and \\
& Khurana, 2020; Mehmood et al., 2020; Misra et al., 2020; Perrone et al., 2020; Priyanka et al., 2020; Roth et al., \\
& 2020; Trebicki, 2020. \\
\hline \multirow{2}{*}{ Weeds } & Billore, 2019; Manisankar and Ramesh, 2019; Ziska, Blumenthal and Franks, 2019; Karaca and Dursun, 2020; \\
& Ruttledge and Chauhan, 2020; Sun et al., 2020. \\
\hline \multirow{2}{*}{ Combinations of pest groups } & Heeb, Jenner and Cock, 2019; Santini and Battisti, 2019; Trebicki and Finlay, 2019; Bajwa et al., 2020; Bonello \\
& etal., 2020; Jabran, Florentine and Chauhan, 2020; Jactel etal., 2020.
\end{tabular}

E Notes: The examples listed were subjectively selected, were all published from 2019 to September 2020 in journals and books, and include mini-reviews.

Review articles on the same topic, published from 1988 until 2011, are compiled in Juroszek and von Tiedemann (2013a).

Table 6. Examples of gaps in climate-change research related to plant pests

\begin{tabular}{|c|c|}
\hline RESEARCH GAP (RESEARCH PROPOSAL) & SELECTED REFERENCE \\
\hline Potential opportunities related to crop protection less explored & Sutherst etal., 2007. \\
\hline Below-ground species less investigated than above-ground species & Pritchard, 2011. \\
\hline Tropical species less studied than species in subtropical and temperate regions & Ghini, Bettiol and Hamada, 2011. \\
\hline Pests in unmanaged systems less investigated than in managed systems & Anderson etal., 2004. \\
\hline $\begin{array}{l}\text { Research is confined to a few particularly important pest species; many others are less well studied or not } \\
\text { studied at all (e.g. bacteria and viruses much less investigated than above-ground pathogenic fungi) }\end{array}$ & Frank, 2020; Jones, 2016. \\
\hline $\begin{array}{l}\text { Many more multi-factorial field experiments that consider interactions of temperature, water and } \mathrm{CO}_{2} \\
\text { needed (simulation of future real-world conditions, e.g. using free air } \mathrm{CO}_{2} \text { enrichment approaches) }\end{array}$ & $\begin{array}{l}\text { Tenllado and Canto, 2020; Vila et al., } \\
2021 .\end{array}$ \\
\hline Biotic interactions across trophic levels poorly known, including adaptive potential of species & Van der Putten, Macel and Visser, 2010. \\
\hline Comprehensive summary of past results in agriculture and horticulture needed & Juroszek etal., 2020. \\
\hline Evaluation of current plant-protection methods under climate change scenarios needed & $\begin{array}{l}\text { Delcour, Spanoghe and Uyttendaele, } \\
2015 .\end{array}$ \\
\hline $\begin{array}{l}\text { Long-term data sets needed to discriminate potential climate-change effects on pests and disease from } \\
\text { confounding factors such as changes in management }\end{array}$ & Garrett etal., 2016, 2021. \\
\hline $\begin{array}{l}\text { Simulations of future pest risk should more often be linked to crop models to inform potential yield losses; } \\
\text { also, potential adaptation and mitigation measures should be included in the model runs where possible }\end{array}$ & Juroszek and von Tiedemann, 2015. \\
\hline Much more adaptation and mitigation research needed to minimize increasing risks & Hoffmann etal., 2019. \\
\hline $\begin{array}{l}\text { Frameworks needed for adapting decision-support systems to new frequency distributions of weather } \\
\text { conditions, and even completely new scenarios }\end{array}$ & Garrett etal., 2020a. \\
\hline
\end{tabular}

Notes: The references listed were subjectively selected; however, post-2010 publications were preferred in order to demonstrate that research gaps are still prevalent. In general, each example applies equally well to insect pests, pathogens, and weeds. Modified after Juroszek and von Tiedemann (2013a) End Juroszek etal. (2020). 


\section{Studies on the effects of climate change on natural enemies}

The impact of climate change on natural enemies and antagonists and the subsequent effect of this on pest control are not yet well understood (Eigenbrode, Davis and Crowder, 2015). In the case of grape pest insects, it has been suggested that future pest management should be based on a sound set of field data collected for both pests and antagonists under climate-change conditions (Reineke and Thiéry, 2016). A better understanding of the impact of climate change on ecological processes, including at community level, will allow general principles to be incorporated into management practices (Macfayden, McDonald and Hill, 2018).

\section{Forestry and unmanaged ecosystems}

Pests have been investigated much more in agriculture compared to forestry settings (Ormsby and Brenton-Rule, 2017), and research related to unmanaged ecosystems is rare (Harvell etal., 2002). This highlights the need for multidisciplinary collaboration, coordination and knowledge exchange in climate-change biology research to bring together scientists working on different biota within the same ecosystem, for instance plant pathologists and entomologists (Jactel etal., 2020), and those working on different ecosystems and sectors, such as agriculture, forestry and unmanaged ecosystems (e.g. the "Circular Health" or "One Health" approaches).

\section{International cooperation}

International cooperation is critical to the success of countries in adapting pest-management strategies to climate change. This is because effective management by one farmer or one country affects the success of others, as pests do not respect borders. International cooperation may be global or regional. A proposed new global surveillance system for crop disease, for example, will integrate across diagnostic networks, data management networks, risk assessment networks, and communication networks (Carvajal-Yepes et al., 2019).

Establishment of a mechanism for global phytosanitary research coordination, as suggested in the IPPC Strategic Framework 2020-2030 (FAO, 2021b), could increase scientific collaboration, enhance coordination of effort, optimize the use of resources and facilitate alignment of goals. By so doing it could not only help to advance the science, but also strengthen the scientific foundations of international efforts to assess and manage the impact of climate change on plant health, thereby helping to protect agriculture, the environment and trade activities from pests.

At a regional level, scenario analysis of potential responses to climate change can help to inform strategies for adaptation of regional disease management (Garrett et al., 2018). However, although many national and regional plant protection organizations work to monitor and contain outbreaks of crop pests, many countries do not efficiently exchange information, thereby delaying coordinated responses to prevent disease establishment and spread. Support for capacity building in these countries should therefore form an essential component of international cooperation. With the support of international organizations, global forums for information sharing could be extremely useful. The experience currently gained in the organization of on-line meetings throughout the COVID-19 pandemic will help in fostering long-distance contacts and interactions, with a significant saving of time and money. 


\section{Capacity building}

While COVID-19 has disrupted most aspects of life, including food systems and educational systems, it has also shown the potential for new shared programmes for capacity building as teaching has moved online. Addressing inequalities in Internet access will help to support these new online capacity-building opportunities.

There are various ways in which countries may build their capacity to cope with and adapt to climate change. The following examples serve to highlight some of the possibilities.

The Consultative Group on International Agricultural Research (CGIAR) - a global research partnership on food security - is forming a new "One CGIAR" beginning in 2022, with the aim of deploying scientific innovations for food, land and water systems quicker, at a larger scale and at reduced cost. It may be advisable to maintain pest management as a key component of the new One CGIAR strategy to strengthen adaptive capacity globally and especially in national programmes that are still building their capacity to address these problems. These can include "no-regrets" adaptation approaches, such as generally strengthening systems and their ability to respond to new challenges from climate change (Heltberg, Siegel and Jorgensen, 2009). The idea behind these types of approaches is that many system improvements will be valuable whether or not specific current climate-change scenarios play out. Because new pest introductions are often at least as impactful as climate-change effects, it is straightforward to design no-regrets improvements to pest-management systems. There may be limits to no-regrets options (Dilling etal., 2015), but there is much room to improve pest- and disease-management systems on farms and in regional management. An IPPC phytosanitary capacity evaluation can be used to evaluate a country's readiness to respond to plant-disease challenges (Day, Quinlan and Ogutu, 2006; IPPC Secretariat, 2012). This is another example of a potential no-regrets approach, since enhancing capacity will have benefits whether or not climate-change scenarios play out as expected, and will probably also result in cost-benefit improvements.

Building capacity to adapt to change also means finding ways of managing financial risk. This can sometimes be achieved, at least in part, through crop insurance, which is an attractive option for protecting farmers' livelihoods under climate-change stresses. However, it does not necessarily protect productivity and may provide an incentive for production of particular crops to continue in regions where the crops are no longer suited to the new environment (Falco etal., 2014).

Elements of effective altruism ("providing benefits for society") - whereby some share of effort would be invested in evaluating worst-case scenarios for pest effects and how they may be addressed - may also prove useful in helping countries adapt to climate change (Garrett et al., 2020b). 
o conclude, the evidence reviewed in this report strongly indicates that in many cases climate change will result in increasing problems related to plant health in managed (e.g. agriculture, horticulture, forestry), semi-managed (e.g. national parks) and presumably also unmanaged ecosystems. Adjustments in plant-protection strategies are already necessary today because of recent climate changes and adjustments will be even more crucial in the future, assuming the projected climate-change scenarios come true. Climate-smart pest management, which involves the implementation across farms and landscapes of holistic approaches, is mostly based on selected existing management methods, in order to be able to enhance mitigation and strengthen resilience. Maintaining managed and unmanaged ecosystem services and produce, including food, under climate-change conditions is of paramount importance, and preventive and curative plant-protection measures are key components to the maintenance of current and future food security. 


\section{References}

Abd-Elgawad, M.M.M. 2020. Managing nematodes in Egyptian citrus orchards. Bulletin of the National Research Centre, 44: 41 [online]. [Cited 28 December 2020]. https://doi.org/10.1186/s42269-020-00298-9

Ainsworth, E.A. \& Long, S.P. 2021. 30 years of free-air carbon enrichment (FACE): What have we learned about future crop productivity and its potential for adaptation? Global Change Biology, 27: 27-49.

Al-Ayedh, H.Y. Al-. 2017. The current state of the art research and technologies on RPW management. Paper presented at the "Scientific Consultation and High-Level Meeting on Red Palm Weevil Management", 29-31 March 2017, Rome, FAO.

Albajes, R., Gullino, M.L., van Lenteren, J.C. \& Elad, Y., eds. 1999. Integrated pest and disease management in greenhouse crops. Dordrecht, The Netherlands, Kluwer Academic Publishers.

Almeida, R.P.P., Blua, M.J., Lopes, J.R.S. \& Purcell, A.H. 2005. Vectortransmission of Xylella fastidiosa: Applying fundamental knowledge to generate disease management strategies. Annals of the Entomological Society of America, 98: 775-786.

Almekinders, C.J., Walsh, S., Jacobsen, K.S., Andrade-Piedra, J.L., McEwan, M.A., de Haan, S., Kumar, L. \& Staver, C. 2019. Why interventions in the seed systems of roots, tubers and bananas crops do not reach their full potential. Food Security, 11: 23-42.

Altermatt, F. 2010. Climatic warming increases voltinism in European butterflies and moths. Proceedings of the Royal Society B: Biological Sciences, 277: 1281-1287.

Altizer, S., Ostfeld, R.S., Johnson, P.T.J., Kutz, S. \& Harvell, C.D. 2013. Climate change and infectious diseases: From evidence to a predictive framework. Science, 341: 514-519.

Amanifar, N., Taghavi, M., Izadpanah, K. \& Babaei, G. 2014. Isolation and pathogenicity of Xylella fastidiosa from grapevine and almond in Iran. Phytopathologia Mediterranea, 53(2): 318-327.

Anderegg, W.R.L., Kane, J.M. \& Anderegg, L.D.L. 2013. Consequences of widespread tree mortality triggered by drought and temperature stress. Nature Climate Change, 3: 30-36.

Anderson, P.K., Cunningham, A.A., Patel, N.G., Morales, F.J., Epstein, P.R. \& Daszak, P. 2004. Emerging infectious diseases of plants: Pathogen pollution, climate change and agrotechnology drivers. Trends in Ecology and Evolution, 19: 535-544.

Angelotti, F., Hamada, E., Magalhaes, E.E., Ghini, R., Garrido, L.D.R. \& Junior, M.J.P. 2017. Climate change and the occurrence of downy mildew in Brazilian grapevines. Pesquisa Agropecuaria Brasileira, Brasilia, 52: 426-434.

Aukema, J.E., Leung, B., Kovacs, K., Chivers, C., Britton, K.O., Englin, J., Frankel, S.J. etal. 2011. Economic impacts of non-native forest insects in the continental United States. PLOS ONE 6(9): e24587 [online]. [Cited 28 December 2020]. https://doi.org/10.1371/journal.pone.0024587

Avelino, J., Cristancho, M., Georgiou, S., Imbach, P., Aguilar, L., Bornemann, G., Läderach, P., Anzueto, F., Hruska, A.J. \& Morales, C. 2015. The coffee rust crises in Colombia and Central America (2008-2013): Impacts, plausible causes and proposed solutions. Food Security, 7: 303-321.

Bairstow, K.A., Clarke, K.L., McGeoch, M.A. \& Andrew, N.R. 2010. Leaf miner and plant galler species richness on Acacia: Relative importance of plant traits and climate. Oecologia, 163: 437-448.

Bajwa, A.A., Farooq, M., Al-Sadi, A.M., Nawaz, A., Jabran, K. \& Siddique, K.H.M. 2020. Impact of climate change on biology and management of wheat pests. Crop Protection, 137: 105304 [online]. [Cited 31 March 2021]. https://doi.org/10.1016/j.cropro.2020.105304 
Bale, J.S. \& Hayward, S.A.L. 2010. Insect overwintering in a changing climate. The Journal of Experimental Biology, 213: 980-994.

Battilani, P., Toscano, P., van der Fels-Klerx, H.J., Moretti, A., Camardo Leggieri, M., Brera, C., Rortais, A. etal. 2016. Aflatoxin B1 contamination in maize in Europe increases due to climate change. Scientific Reports, 6: 24328 [online]. [Cited 28 December 2020]. https://doi.org/10.1038/srep24328

Battisti, A. 2008. Forests and climate change; lessons from insects. iForest - Biogeosciences and Forestry, 1: 1-5 [online]. [Cited 28 December 2020]. https://doi.org/10.3832/ifor0210-0010001

Battisti, A., Stastny, M., Buffo, E. \& Larsson, S. 2006. A rapid altitudinal range expansion in the pine processionary moth produced by the 2003 climatic anomaly. Global Change Biology, 12: 662-667.

Bebber, D.P, Ramotowski, M.A.T. \& Gurr, S.J. 2013. Crop pests and pathogens move polewards in a warming world. Nature Climate Change, 3: 985-988.

Bentz, B.J. \& Jönsson, A.M. 2015. Modeling bark beetle responses to climate change. In F.E. Vega \& R.W. Hofstetter, eds. Bark beetles - biology and ecology of native and invasive species, pp. 533-553. Cambridge MA, Academic Press, Elsevier.

Bergsma-Viami, M., van de Bilt, J.L.J., Tjou-Tam-Sin, N.N.A., van de Vossenberg, B.T.L.H. \& Westenberg, M. 2015. Xylella fastidiosa in Coffea arabica ornamental plants imported from Costa Rica and Honduras in The Netherlands. Journal of Plant Pathology, 97: 395.

Betz, O., Srisuka, W. \& Puthz, V. 2020. Elevational gradients of species richness, community structure, and niche occupation of tropical roove beetles (Coleoptera: Staphylinidae: Steninae) across mountain slopes in Northern Thailand. Evolutionary Ecology, 34: 193-216.

Biber-Freudenberger, L., Ziemacki, J., Tonnang, H.E.Z. \& Borgemeister, C. 2016. Future risks of pest species under changing climatic conditions. PLOS ONE, 11: e0153237 [online]. [Cited 28 December 2020]. https://doi.org/10.1371/journal.pone.0153237

Billore, S.D. 2019. Weeds in soybean vis-à-vis other crops - a review. Soybean Research, 17: 1-21.

Bingna, H., Feifei, C., Yue, S., Kun, Q., Yan, W., Changjiao, S., Xiang, Z. etal. 2018. Advances in targeted pesticides with environmentally responsive controlled release by nanotechnology. Nanomaterials (Basel, Switzerland), 8(2): 102 [online]. [Cited 28 December 2020]. https://doi.org/10.3390/nano8020102

Björkman, C. \& Niemelä, P. 2015. Climate change and insect pests. Wallingford, UK, CABI.

Bonello, P., Campbell, F.T., Cipollini, D., Conrad, A.O., Farinas, C., Gandhi, K.J.K., Hain, F.P. et al. 2020. Invasive tree pests devastate ecosystems - a proposed new response framework. Frontiers in Forests and Global Change, 3: 2 [online]. [Cited 28 December 2020]. https://doi.org/10.3389/ffgc.2020.00002

Borkataki, S., Reddy, M.D., Nanda, S.P. \& Taye, R.R. 2020. Climate change and its possible impact on the existence of insect pests. Ecology, Environment and Conservation, 26: S271-S277.

Bosso, L., Russo, D., Febbraro, M.D., Cristinzio, G. \& Zoina, A. 2016. Potential distribution of Xylella fastidiosa in Italy: A maximum entropy model. Phytopathologia Mediterranea, 55: 62-72.

Bregaglio, S., Donatelli, M. \& Confalonieri, R. 2013. Fungal infections of rice, wheat, and grape in Europe in 2030-2050. Agronomy for Sustainable Development, 33: 767-776.

Burne, A.R. 2019. Pest risk assessment: Halyomorpha halys (Brown marmorated stink bug). Version 1, June 2019. Ministry for Primary Industries, New Zealand.

Butterworth, M.H., Semenov, M.A., Barnes, A., Moran, D., West, J.S. \& Fitt, B.D.L. 2010. North-south divide: Contrasting impacts of climate change on crop yields in Scotland and England. Journal of the Royal Society Interface, 7: 123-130. 
CABI. 2021a. Bursaphelenchus xylophilus (pine wilt nematode) datasheet. In Invasive Species Compendium [online]. Wallingford, UK, CABI. [Cited 16 March 2021]. https://www.cabi.org/isc/datasheet/10448\#todistribution

CABI. 2021b. Agrilus planipennis (emerald ash borer) datasheet. In Invasive Species Compendium [online]. Wallingford, UK, CABI. [Cited 19 March 2021]. https://www.cabi.org/isc/datasheet/3780\#todistribution

CABI. 2021c. Bactrocera oleae (olive fruit fly) datasheet. In Invasive Species Compendium [online]. Wallingford, UK, CABI. [Cited 19 March 2021]. https://www.cabi.org/isc/datasheet/17689\#todistribution

Carvajal-Yepes, M., Cardwell, K., Nelson, A., Garrett, K.A., Giovani, B., Saunders, D., Kamoun, S. etal. 2019. A global surveillance system for crop diseases. Science, 364: 1237-1239.

Castellanos-Frías, D., de León, D.G., Bastida, F. \& González-Andújar, J.L. 2016. Predicting global geographical distribution of Lolium rigidum (rigid ryegrass) under climate change. The Journal of Agricultural Science, 154: 755-764.

Castillo, N.E.T., Melchior-Martínez, E.M., Sierra, J.S.O., Ramirez-Mendoza, R.A., Parra-Saldivar, R. \& Iqbal, H.M.N. 2020. Impact of climate change and early development of coffee rust - an overview of control strategies to preserve organic cultivars in Mexico. Science of the Total Environment, 738: 140225.

Chakraborty, S. \& Newton, A.C. 2011. Climate change, plant diseases and food security: An overview. Plant Pathology, 60: 2-14.

Chakraborty, S., Pangga, I.B. \& Roper, M.M. 2012. Climate change and multitrophic interactions in soil: The primacy of plants and functional domains. Global Change Biology, 18: 2111-2125.

Chang, F.P., Kuang, L.Y., Huang, C.A., Jane, W.N., Hung, Y., Hsing, Y.I. \& Mou, C.Y. 2013. A simple plant gene delivery system using mesoporous silica nanoparticles as carriers. Journal of Materials Chemistry B: Materials for Biology and Medicine, 1(39): 5279-5287 [online]. [Cited 28 December 2020]. https://doi.org/10.1039/c3tb20529k

Chen, J. \& Henny, R.J. 2006. Somaclonal variation: An important source for cultivar development of floriculture crops. In J.A. Teixeira da Silva, ed. Floriculture, ornamental and plant biotechnology, Volume II, pp. 244-253. London, Global Science Books.

Choudhary, J.S., Kumari, M. \& Fand, B.B. 2019. Linking insect pest models with climate change scenarios to project against future risks of agricultural insect pests. CAB Reviews, 14: 055 [online]. [Cited 28 December 2020]. https://www.cabi.org/cabreviews/review/20193460085

Cilas, C. \& Bastide, P. 2020. Challenges to cocoa production in the face of climate change and spread of pests and diseases. Agronomy, 10: 1232 [online]. [Cited 28 December 2020]. https://doi.org/10.3390/agronomy10091232

Clements, D.R. \& DiTommaso, A. 2011. Climate change and weed adaptation: Can evolution of invasive plants lead to greater range expansion than forecasted? Weed Research, 51:227-240.

Clements, D.R., DiTommaso, A. \& Hyvönen, T. 2014. Ecology and management of weeds in a changing climate. In B.S. Chauhan \& G. Mahajan, eds. Recent advances in weed management, pp. 13-37. New York, USA, Springer Science + Business Media.

Cooke, D.E.L., Cano, L.M., Raffaele, S., Bain, R.A., Cooke, L.R., Etherington, G.J., Deahl, K.L. etal. 2012. Genome analyses of an aggressive and invasive lineage of the Irish potato famine pathogen. PLoS Pathogens 8(10): e1002940 [online]. [Cited 28 December 2020]. https://doi.org/10.1371/journal.ppat.1002940

Cornara, D., Morente, M., Markheiser, A., Bodino, N., Tsai, C.-W., Fereres, A., Redak, R.A., Perring, T.M. \& Lopes, J.R.S. 2019. An overview on the worldwide vectors of Xylella fastidiosa. Entomologia Generalis, 39(3-4): 157-181.

Cunningham, F.J., Goh, N.S., Demirer, G.S., Matos, J.L. \& Landry, M.P. 2018. Nanoparticle-mediated delivery towards advancing plant genetic engineering. Trends in Biotechnology, 36(9): 882-897. 
Daughtrey, M. \& Buitenhuis, R. 2020. Integrated pest and disease management in greenhouse ornamentals. In M.L. Gullino, R. Albajes \& P.C. Nicot, eds. Integrated pest and disease management in greenhouse crops, pp. 625-679. Dordrecht, The Netherlands, Springer Nature.

Day, R., Quinlan, M. \& Ogutu, W. 2006. Analysis of the application of the phytosanitary capacity evaluation tool. Report to the Secretariat of the International Plant Protection Convention.

Debelo, D.G. 2020. Predictions of climate change impacts on agricultural insect pests vis-à-vis food crop productivity: A critical review. Ethiopian Journal of Science and Sustainable Development, 7: 18-26.

Delcour, I., Spanoghe, P. \& Uyttendaele, M. 2015. Literature review: Impact of climate change on pesticide use. Food Research International, 68: 7-15.

Delucia, E.H., Nabity, P.D., Zavala, J.A. \& Berenbaum, M.R. 2012. Climate change: Resetting plant-insect interactions. Plant Physiology, 160: 1677-1685.

Deutsch, C.A., Tewksbury, J.J., Huey, R.B., Shelton, K.S., Ghalambor, C.K., Haak, D.C. \& Martin, P.R. 2008. Impacts of climate warming on terrestrial ectotherms across latitude. Proceedings of the National Academy of Sciences USA, 105: $6668-6672$.

Deutsch, C.A., Tewksbury, J.J., Tigchelaar, M., Battisti, D.S., Merrill, S.C., Huey, R.B. \& Naylor, R.L. 2018. Increase in crop losses to insect pests in a warming climate. Science, 361: 915-919.

Diamond, S.E. 2018. Contemporary climate-driven range shifts: Putting evolution back on the table. Functional Ecology, 32: 1652-1665.

Dilling, L., Daly, M.E., Travis, W.R., Wilhelmi, O.V. \& Klein, R.A. 2015. The dynamics of vulnerability: Why adapting to climate variability will not always prepare us for climate change. Wiley Interdisciplinary Reviews: Climate Change, 6: 413-425.

Dita, M., Barquero, M., Heck, D., Mizubuti, E.S.G. \& Staver, C.P. 2018. Fusarium wilt of banana: Current knowledge on epidemiology and research needs toward sustainable disease management. Frontiers in Plant Science, 9: 1468 [online]. [Cited 28 December 2020]. https://doi.org/10.3389/fpls.2018.01468

Diyanat, M., Saeidian, H., Baziar, S. \& Mirjafary, Z. 2019. Preparation and characterization of polycaprolactone nanocapsules containing pretilachlor as a herbicide nanocarrier. Environmental Science and Pollution Research International, 26(21): 21579-21588 [online]. [Cited 28 December 2020]. https://doi.org/10.1007/s11356-019-05257-0

Donovan, G.H., Butry, D.T., Michael, Y.L., Prestemon, J.P., Liebhold, A.M., Demetrios Gatziolis, D. \& Mao, M.Y. 2013. The relationship between trees and human health: Evidence from the spread of the emerald ash borer. American Journal of Preventive Medicine, 44(2): 139-145.

Duan, J.J., Bauer, L.S., Van Driesche, R., Schmude, J.M., Petrice, T., Chandler, J.L. \& Elkinton, J. 2020. Effects of extreme low winter temperatures on the overwintering survival of the introduced larval parasitoids Spathius galinae and Tetrastichus planipennisi: Implications for biological control of emerald ash borer in North America. Journal of Economic Entomology, 113: 1145-1151.

Duncan, L.W. 2009. Managing nematodes in citrus orchards. In A. Ciancio \& K.G. Mukerji, eds. Integrated management of fruit crops and forest nematodes, pp. 135-173. Dordrecht, The Netherlands, Springer Science+Business Media B.V.

Duran, A., Gryzenhout, M., Slippers, B., Ahumada, R., Rotella, A., Flores, F., Wingfield, B.D. \& Wingfield, M.J. 2008. Phytophthora pinifolia sp. nov. associated with a serious needle disease of Pinus radiata in Chile. Plant Pathology, 57: 715-727.

Eastburn, D.M., McElrone, A.J. \& Bilgin, D.D. 2011. Influence of atmospheric and climate change on plant-pathogen interactions. Plant Pathology, 60: 54-69.

Edmonds, R.L. 2013. General strategies of forest disease management. In P. Gonthier \& G. Nicolotti, eds. Infectuous forest diseases, pp. 29-49. Wallingford, UK and Boston, MA, CABI. 
Eigenbrode, S.D., Davis, T.S. \& Crowder, D.W. 2015. Climate change and biological control in agricultural systems: Principles and examples from North America. In C. Björkman \& P. Niemelä, eds. Climate change and insect pests, pp. 119-135. Wallingford, UK, CABI.

El-Mergawy, R.A.A.M. \& Al-Ajlan, A.M. 2011. Red palm weevil, Rhynchophorus ferrugineus (Olivier): Economic importance, biology, biogeography and integrated pest management. Journal of Agricultural Science and Technology, 1: 1-23.

El-Sabea, A.M. El-, Faleiro, J. \& Abo-El-Saad, M.M. 2009. The threat of red palm weevil Rhynchophorus ferrugineus to date plantations of the Gulf region in the Middle-East: An economic perspective. Outlooks on Pest Management, 20(3): $131-134$.

EPPO (European and Mediterranean Plant Protection Organization). 2020a. A1 list of pests recommended for regulation as quarantine pests, version 2020-09. In European and Mediterranean Plant Protection Organization [online]. [Cited 28 December 2020]. https://www.eppo.int/ACTIVITIES/plant_quarantine/A1_list

EPPO (European and Mediterranean Plant Protection Organization). 2020b. First report of Spodoptera frugiperda in Israel. EPPO Reporting Service No. 08-2020: 2020/161. In EPPO Global Database [online]. Paris. [Cited 28 December 2020]. https://gd.eppo.int/reporting/article-6839

EPPO (European and Mediterranean Plant Protection Organization). 2021a. Anoplophora glabripennis. EPPO datasheets on pests recommended for regulation. In EPPO Global Database [online]. [Cited 20 February 2021].

https://gd.eppo.int/taxon/ANOLGL/datasheet

EPPO (European and Mediterranean Plant Protection Organization). 2021b. Agrilus planipennis. EPPO datasheet as updated January 2021. In EPPO Global Database [online]. [Cited 20 February 2021].

https://gd.eppo.int/taxon/AGRLPL/datasheet

EPPO (European and Mediterranean Plant Protection Organization). 2021c. Current global distribution of Bactrocera dorsalis (DACUDO) as registered in January 2021 and reporting service articles. In EPPO Global Database [online]. [Cited 20 February 2021]. https://gd.eppo.int/taxon/DACUDO/distribution and https://gd.eppo.int/taxon/DACUDO/reporting

Erikson, L. \& Griffin, R. 2014. The international regulatory framework. In G. Gordh \& S. McKirdy, eds. The handbook of plant biosecurity, pp. 27-44. Dordrecht, The Netherlands, Springer Science+Business Media.

Evans, N., Baierl, A., Semenov, M.A., Gladders, P. \& Fitt, B.D.L. 2008. Range and increase of a plant disease increased by global warming. Journal of the Royal Society Interface, 5: 625-631.

Fahim, M.A., Hassanein, M.K., Abou Hadid, A.F. \& Kadah, M.S. 2011. Impacts of climate change on the widespread and epidemics of some tomato diseases during the last decade in Egypt. Acta Horticulturae, 914: 317-320.

Fahim, M.A., Hassanein, M.K. \& Mostafa, M.H. 2003. Relationships between climatic conditions and potato late blight epidemic in Egypt during winter seasons 1999-2001. Applied Ecology and Environmental Research, 1(1-2): 159-172.

Falco, S.D., Adinolfi, F., Bozzola, M. \& Capitanio, F. 2014. Crop insurance as a strategy for adapting to climate change. Journal of Agricultural Economics, 65: 485-504.

FAO. 2008. Climate-related transboundary pests and diseases. Technical background document from the Expert consultation held on 25 to 27 February 2008. Rome, FAO. 59 pp. (also available at http://www.fao.org/3/a-ai785e.pdf).

FAO. 2020. Red palm weevil: Guidelines on management practices. Rome, FAO, ix + 86 pp. (also available at https://doi.org/10.4060/ca7703en).

FAO. 2021a. Desert locust upsurge - progress report on the response in Southwest Asia (May-December 2020). Rome, FAO. 18 pp. (also available at http://www.fao.org/3/cb2358en/cb2358en.pdf).

FAO. 2021b. Strategic framework for the International Plant Protection Convention (IPPC) 2020-2030. Rome, FAO on behalf of the IPPC Secretariat. 40 pp. 
Fedchock, C., Gould, W.P, Hennessey, M.K., Mennig, X. \& Sosa, E. 2006. Trip report - Spanish lemon site visit: September 23-30, 2006. Riverdale, USA, United States Department of Agriculture, Animal and Plant Health Inspection Services.

Fiaboe, K.K.M., Peterson, A.T., Kairo M.T.K. \& Roda, A.L. 2012. Predicting the potential worldwide distribution of the red palm weevil Rhynchophorus ferrugineus (Olivier) (Coleoptera: Curculionidae) using ecological niche modeling. Florida Entomologist, 95: 559-673.

Flitters, N.E. 1963. Observations on the effect of hurricane "Carla" on insect activity. International Journal of Biometeorology, 6: 85-92.

Frank, S.D. 2020. Review of the direct and indirect effects of warming and drought on scale insect pests of forest systems. Forestry: An International Journal of Forest Research, cpaa033 [online]. [Cited 28 December 2020]. https://doi.org/10.1093/forestry/cpaa033

Frem, M., Chapman, D., Fucilli, V., Choueiri, E., Moujabber, M.E., Notte, P.L. \& Nigro, F. 2020. Xylella fastidiosa invasion of new countries in Europe, the Middle East and North Africa: Ranking the potential exposure scenarios. NeoBiota, 59: 77-97 [online]. [Cited 28 December 2020]. https://doi.org/10.3897/neobiota.59.53208

Fussmann, K.E., Schwarzmüller, F., Brose, U., Jousset, A. \& Rall, B.C. 2014. Ecological stability in response to warming. Nature Climate Change, 4: 206-210.

García-Bastidas, F.A., Quintero-Vargas, Ayala-Vasquez, M., Schermer, T, Seidl, M.F., Santos-Paiva, M., Noguera A.M. etal. 2019. First report of Fusarium wilt tropical race 4 in Cavendish bananas caused by Fusarium odoratissimum in Colombia. Plant Disease [online]. [Cited 31 March 2021]. https://doi.org/10.1094/PDIS-09-19-1922-PDN

Garibaldi, A. \& Gullino, M.L. 1995. Focus on critical issues in soil and substrate disinfestation towards the year 2000. Acta Horticulturae, 382: 21-36.

Garibaldi, L., Kitzberger, T. \& Chaneton, E.J. 2011. Environmental and genetic control of insect abundance and herbivory along a forest elevational gradient. Oecologia, 167: 117-129.

Garrett, K.A., Alcalá-Briseño, R., Andersen, K.F., Brawner, J., Choudhury, R., Delaquis, E., Fayette, J., Poudel, R., Purves, D. \& Rothschild, J. 2020b. Effective altruism as an ethical lens on research priorities. Phytopathology, 110: 708-722.

Garrett, K.A., Alcalá-Briseño, R.I., Andersen, K.F., Buddenhagen, C.E., Choudhury, R.A., Fulton, J.C., Hernandez Nopsa, J.F., Poudel, R. \& Xing, Y. 2018. Network analysis: A systems framework to address grand challenges in plant pathology. Annual Review of Phytopathology, 56: 559-580.

Garrett, K.A., Alcalá-Briseño, R.I., Andersen, K.F., Choudhury, R.A., Dantes, W., Fayette, J., Fulton, J.C., Poudel, R. \& Staub, C.G. 2020a. Adapting disease management systems under global change. In J.B. Ristaino \& A. Records, eds. Emerging plant diseases and global food security, pp. 1-13. St. Paul, USA, APS Press.

Garrett, K.A., Dendy, S.P., Frank, E.E., Rouse, M.N. \& Travers, S.E. 2006. Climate change effects on plant disease: Genomes to ecosystems. Annual Review of Phytopathology, 44: 489-509.

Garrett, K.A., Nita, M., De Wolf, E.D., Esker, P.D., Gomez-Montano, L. \& Sparks, A.H. 2016. Plant pathogens as indicators of climate change. In T.M. Letcher, ed. Climate change: Observed impacts on planet Earth, 2nd edn, pp. 325-338. Amsterdam, The Netherlands, Elsevier.

Garrett, K.A., Nita, M., De Wolf, E.D., Esker, P.D., Gomez-Montano, L. \& Sparks, A.H. 2021. Plant pathogens as indicators of climate change. In T.M. Letcher, ed. Climate change: Observed impacts on planet Earth, 3rd edn, pp. 499-513. Amsterdam, The Netherlands, Elsevier.

Ge X., He, S., Wang, T., Yan, W. \& Zong, S. 2015. Potential distribution predicted for Rhynchophorus ferrugineus in China under different climate warming scenarios. PLOS ONE 10(10): e0141111 [online]. [Cited 28 December 2020].

https://doi.org/10.1371/journal.pone.0141111 
Ghini, R., Bettiol, W. \& Hamada, E. 2011. Diseases in tropical plantation crops as affected by climate changes: Current knowledge and perspectives. Plant Pathology, 60: 122-132.

Ghini, R., Hamada, E. \& Bettiol, W. 2008. Climate change and plant diseases. Scientia Agrícola, 65: 98-107.

Ghini, R., Hamada, E. \& Bettiol, W. 2011. Impactos das mudanças climáticas sobre doenças de importantes culturas no Brasil. Brasília, DF, Jaguariúna: Embrapa Meio Ambiente.

Ghini, R., Hamada, E., Pedro Júnior, M.J. \& Gonçalves, R.R.V. 2011. Incubation period of Hemileia vastatrix in coffee plants in Brazil simulated under climate change. Summa Phytopathologica, 37: 85-93.

Gilardi, G., Garibaldi, A. \& Gullino, M.L. 2018. Emerging pathogens as a consequence of globalization and climate change: Leafy vegetables as a case study. Phytopathologia Mediterranea, 57: 146-152.

Gilardi, G., Gisi, U., Garibaldi, A. \& Gullino, M.L. 2017. Effect of elevated atmospheric $\mathrm{CO}_{2}$ and temperature on the chemical and biological control of powdery mildew of zucchini and the Phoma leaf spot of leaf beet. European Journal Plant Pathology, 148: 229-236.

Giovani, B., Blümel, S., Lopian, R., Teulon, D., Bloem, S., Galeano Martínez, C., Beltrán Montoya, C. etal. 2020. Science diplomacy for plant health. Nature Plants, 6: 902-905.

Gitaitis, R. \& Walcott, R. 2007. The epidemiology and management of seedborne bacterial diseases. Annual Review of Phytopathology, 45: 371-397.

Godefroid, M., Cruaud, A., Rossi, J.P. \& Rasplus, J.Y. 2015. Assessing the risk of invasion by tephritid fruit flies: Intraspecific divergence matters. PLOS ONE, 10: e0135209 [online]. [Cited 28 December 2020].

https://doi.org/10.1371/journal.pone.0135209

Godefroid, M., Cruaud, A., Streito, J.C., Rasplus, J.Y. \& Rossi, J. P. 2018. Climate change and the potential distribution of Xylella fastidiosa in Europe. bioRxiv, hal-02791548f [online]. [Cited 28 December 2020]. https://hal.inrae.fr/hal02791548/document

Godefroid, M., Cruaud, A., Streito, J.-C., Rasplus, J.-Y. \& Rossi, J.-P. 2019. Xylella fastidiosa: Climate suitability of European continent. Scientific Reports, 9: 8844 [online]. [Cited 28 December 2020]. https://doi.org/10.1038/s41598-019-45365-y

Godefroid, M., Morente, M., Schartel, T., Cornara, D., Purcell, A., Gallego, D., Moreno, A., Pereira, J.A. \& Fereres, A. 2020. The risk of Xylella fastidiosa outbreaks will decrease in the Mediterranean olive-producing regions. bioRxiv [online]. [Cited 28 December 2020]. https://doi.org/10.1101/2020.07.16.206474

Goergen, G., Kumar, P.L., Sankung, S.B., Togola, A. \& Tamò, M. 2016. First report of outbreaks of the fall armyworm Spodoptera frugiperda (J E Smith) (Lepidoptera, Noctuidae), a new alien invasive pest in West and Central Africa. PLoS ONE 11(10): e0165632. [online]. [Cited 15 March 2021]. https://doi.org/10.1371/journal.pone.0165632

Goswami, A., Roy, I., Sengupta, S. \& Debnath, N. 2010. Novel applications of solid and liquid formulations of nanoparticles against insect pests and pathogens. Thin Solid Films, 519(3): 1252-1257.

Gouache, D., Bensadoun, A., Brun, F., Page, C., Makowski, D. \& Wallach, D. 2013. Modelling climate change impact on Septoria tritici blotch (STB) in France: Accounting for climate model and disease uncertainty. Agricultural and Forest Meteorology, 170: 242-252.

Gouache, D., Roche, R., Pieri, P. \& Bancal, M.O. 2011. Evolution of some pathosystems on wheat and vines. In N. Brisson \& F. Levrault, eds. The green book of the CLIMATOR project (2007-2010): Climate change, agriculture and forests in France - simulations of the impacts on the main species, Section B5 Health, The Topics, pp. 113-126. France, Agency for the Environment and Energy Management (ADEME).

Gregory, P.J., Johnson, S.N., Newton, A.C. \& Ingram, J.S.I. 2009. Integrating pests and pathogens into the climate change/ food security debate. Journal of Experimental Botany, 60: 2827-2838. 
Grillo, R., Dos Santos, N.Z.P., Maruyama, C.R., Rosa, A.H., de Lima, R. \& Fraceto, L.F. 2012. Poly(e-caprolactone) nanocapsules as carrier systems for herbicides: Physico-chemical characterization and genotoxicity evaluation. Journal of Hazardous Materials, 231-232: 1-9.

Grünig, M., Mazzi, D., Calanca, P., Karger, D.N. \& Pellissier, L. 2020. Crop and forest pest metawebs shift towards increased linkage and suitability overlap under climate change. Communications Biology, 3: 233 [online]. [Cited 28 December 2020]. https://doi.org/10.1038/s42003-020-0962-9

Gullino, M.L., Gilardi, G. \& Garibaldi, A. 2014a. Seed-borne pathogens of leafy vegetable crops. In M.L. Gullino \& G. Munkvold, eds. Global perspectives on the health of seeds and plant propagation material, pp. 47-53. Dordrecht, The Netherlands, Springer.

Gullino, M.L., Gilardi, G. \& Garibaldi, A. 2014b. Chemical and non-chemical seed dressing for leafy vegetable crops. In M.L. Gullino \& G. Munkvold, eds. Global perspectives on the health of seeds and plant propagation material, pp. 125136. Dordrecht, The Netherlands, Springer.

Gullino, M.L., Gilardi, G. \& Garibaldi, A. 2019. Ready-to-eat salad crops: A plant pathogen's heaven. Plant Disease, 103: 2153-2170.

Gullino, M.L. \& Munkvold, G., eds. 2014. Global perspectives on the health of seeds and plant propagation material. Dordrecht, The Netherlands, Springer. 136 pp.

Gullino, M.L., Pugliese, M., Gilardi, G. \& Garibaldi, A. 2018. Effect of increased $\mathrm{CO}_{2}$ and temperature on plant diseases: A critical appraisal of results obtained in studies carried out under controlled environment facilities. Journal of Plant Pathology, 100: 371-389.

Gullino, M.L., Pugliese, M., Paravicini, A., Casulli, E., Rettori, A., Sanna, M. \& Garibaldi, A. 2011. New phytotron for studying the effect of climate change on plant pathogens. Journal of Agricultural Engineering, 1: 1-11.

Gullino, M.L., Tabone, G., Gilardi, G. \& Garibaldi, A. 2020. Effects of elevated atmospheric $\mathrm{CO}_{2}$ and temperature on the management of powdery mildew of zucchini. Journal of Phytopathology, 168: 405-415.

Gutierrez, A.P., Ponti, L. \& Cossu, Q.A. 2009. Effects of climate warming on Olive and olive fly (Bactrocera oleae (Gmelin)) in California and Italy. Climatic Change, 95: 195-217.

Haack, R.A., Jendek, E., Liu, H.P., Marchant, K.R., Petrice, T.R., Poland, T.M. \& Ye, H. 2002. The emerald ash borer: A new exotic pest in North America. Newsletter of the Michigan Entomological Society, 47: 1-5.

Hakata, M., Wada, H., Masumoto-Kubo, C., Tanaka, R., Sato, H. \& Morita, S. 2017. Development of a new heat tolerance assay system for rice spikelet sterility. Plant Methods, 13(1): 34 [online]. [Cited 28 December 2020]. https://doi.org/10.1186/s13007-017-0185-3

Hannukkala, A.O., Kaukoranta, T., Lehtinen, A. \& Rahkonen, A. 2007. Late-blight epidemics on potato in Finland, 1933-2002: Increased and earlier occurrence of epidemics associated with climate change and lack of rotation. Plant Pathology, 56: 167-176.

Harvell, C.D., Mitchell, C.E., Ward, J.R., Altizer, S., Dobson, A.P., Ostfeld, R.S. \& Samuel, M.D. 2002. Climate warming and disease risk for terrestrial and marine biota. Science, 296: 2158-2162.

Harvey, J.A., Heinen, R., Gols, R. \& Thakur, M.P. 2020. Climate change-mediated temperature extremes and insects: From outbreaks to breakdowns. Global Change Biology, 26: 6685-6701.

Heeb, L., Jenner, E. \& Cock, M.J.W. 2019. Climate-smart pest management: Building resilience of farms and landscapes to changing pest threats. Journal of Pest Science, 92: 951-969.

Heltberg, R., Siegel, P.B. \& Jorgensen, S.L. 2009. Addressing human vulnerability to climate change: Toward a 'no-regrets' approach. Global Environmental Change, 19: 89-99. 
Heraud, J. 2018. Blue River Technology. Resource, 25(6): 12-12.

Herms, D.A. \& McCullough, D.G. 2014. Emerald ash borer invasion of North America: History, biology, ecology, impacts, and management. Annual Review of Entomology, 59: 13-30.

Hill, M.P. \& Thomson, L.J. 2015. Species distribution modelling in predicting response to climate change. In C. Björkman \& P. Niemelä, eds. Climate change and insect pests, pp. 16-37. Wallingford, UK, CABI.

Hoffmann, A.A., Rymer, P.D., Byrne, M., Ruthrof, K.X., Whinam, J., McGeoch, M., Bergstrom, D.M. etal. 2019. Impacts of recent climate change on terrestrial flora and fauna: Some emerging Australian examples. Austral Ecology, 44: 3-27.

Howden, S.M., Gifford, R.G. \& Meinke, H. 2010. Grains. In C. Stokes \& M. Howden, eds. Adapting agriculture to climate change: Preparing Australian agriculture for the future, pp. 21-40. Melbourne, Australia, CSIRO.

Hu, J., Angeli, S., Schuetz, S, Luo, Y. \& Hajek, A.E. 2009. Ecology and management of exotic and endemic Asian longhorned beetle Anoplophora glabripennis. Agricultural and Forest Entomology, 11: 359-375.

Huang, J. \& Hao, H. 2020. Effects of climate change and crop planting on the abundance of cotton bollworm, Helicoverpa armigera (Hübner) (Lepidoptera: Noctuidae). Ecology and Evolution, 10: 1324-1338.

Hunjan, M.S. \& Lore, J.S. 2020. Climate change: Impact on plant pathogens, diseases, and their management. In K. Jabran, S. Florentine \& B.S. Chauhan, eds. Crop protection under changing climate, pp. 85-100. Springer International Publishing.

Ikegami, M. \& Jenkins, T.A.R. 2018. Estimate global risks of a forest disease under current and future climates using distribution model and simple thermal model - pine wilt disease as a model case. Forest Ecology and Management, 409: 343-352.

Ingram, J.S.I., Gregory, P.J. \& Izac, A.-M. 2008. The role of agronomic research in climate change and food security policy. Agriculture, Ecosystems \& Environment, 126(1-2): 4-12.

IPCC (Intergovernmental Panel on Climate Change). 2013. Climate change 2013: The physical science basis. Contribution of Working Group I to the Fifth Assessment Report of the Intergovernmental Panel on Climate Change (T.F. Stocker, D. Qin, G.-K. Plattner, M. Tignor, S.K. Allen, J. Boschung, A. Nauels, Y. Xia, V. Bex \& P.M. Midgley, eds). Cambridge, United Kingdom and New York, USA, Cambridge University Press. 1535 pp.

IPCC (Intergovernmental Panel on Climate Change). 2014a. Climate change 2014: Synthesis report. Contribution of Working Groups I, II and III to the Fifth Assessment Report of the Intergovernmental Panel on Climate Change (R.K. Pachauri \& L.A. Meyer, coords). Geneva, Switzerland, IPCC. 151 pp. (also available at https://www.ipcc.ch/site/assets/ uploads/2018/02/AR5_SYR_FINAL_Front_matters.pdf).

IPCC (Intergovernmental Panel on Climate Change). 2014b. Summary for policymakers. In Climate change 2014: Impacts, adaptation, and vulnerability. Part A: Global and sectoral aspects. Contribution of Working Group II to the Fifth Assessment Report of the Intergovernmental Panel on Climate Change (C.B. Field, V.R. Barros, D.J. Dokken, K.J. Mach, M.D. Mastrandrea, T.E. Bilir, M. Chatterjee etal., eds). Cambridge, United Kingdom and New York, USA, Cambridge University Press. 32 pp. (also available at https://www.ipcc.ch/site/assets/uploads/2018/02/ar5_wgll_spm_en.pdf).

IPCC (Intergovernmental Panel on Climate Change). 2018. Global warming of $1.5^{\circ} \mathrm{C}$ : An IPCC special report on the impacts of global warming of $1.5^{\circ} \mathrm{C}$ above pre-industrial levels and related global greenhouse gas emission pathways, in the context of strengthening the global response to the threat of climate change, sustainable development, and efforts to eradicate poverty (V. Masson-Delmotte, P. Zhai, H.-O. Pörtner, D. Roberts, J. Skea, P.R. Shukla, A. Pirani etal., eds.). Geneva, Switzerland, IPCC. 630 pp.

IPCC (Intergovernmental Panel on Climate Change). 2019a. Special report on climate change and land [online]. [Cited 19 March 2021]. https://www.ipcc.ch/srccl/

IPCC (Intergovernmental Panel on Climate Change). 2019b. Special report on the ocean and cryosphere in a changing climate [online]. [Cited 19 March 2021]. https://www.ipcc.ch/srocc/ 
IPPC Secretariat. 1997. International Plant Protection Convention. Rome, IPPC Secretariat, FAO (also available at https://assets.ippc.int/static/media/files/publication/en/2019/02/1329129099_ippc_2011-12-01_reformatted.pdf).

IPPC Secretariat. 2012. IPPC national phytosanitary capacity development strategy [online]. Rome, IPPC Secretariat, FAO. 27 pp. [Cited 6 April 2021]. https://assets.ippc.int/static/media/files/publication/en/2016/01/ IPPCCapacityDevelopmentStrategy-en.pdf

IPPC Secretariat. 2016. Plant pest surveillance: A guide to understand the principal requirements of surveillance programmes for national plant protection organizations [online]. Rome, IPPC Secretariat, FAO. [Cited 6 April 2021]. http://www.fao.org/3/ca3764en/CA3764EN.pdf

IPPC Secretariat. 2020a. The first detection of Spodoptera frugiperda, fall armyworm (FAW), in United Arab Emirates. Pest report, 10 May 2020. In International Plant Protection Convention [online]. Rome, FAO. [Cited 28 December 2020]. https://www.ippc.int/en/countries/united-arab-emirates/pestreports/2020/05/the-first-detection-of-fallarmywormfam-spodoptera-frugiperda-in-united-arab-emirates/

IPPC Secretariat. 2020b. Report of first detection of Spodoptera frugiperda, fall armyworm (FAW) in Jordan. Pest report, 27 September 2020. In International Plant Protection Convention [online]. Rome, FAO. [Cited 28 December 2020]. https://www.ippc.int/en/countries/jordan/pestreports/2020/09/report-of-first-detection-of-spodopterafrugiperda-fall-armyworm-faw-in-jordan-1/

IPPC Secretariat. 2021. Spodoptera frugiperda (fall armyworm) detections Australia. Pest report, 5 May 2021. In International Plant Protection Convention [online]. Rome, FAO. [Cited 20 May 2021]. https://www.ippc.int/en/countries/ australia/pestreports/2021/05/spodoptera-frugiperda-fall-armyworm-detections-australia/

Iscaro, J. 2014. The impact of climate change on coffee production in Colombia and Ethiopia. Global Majority E-Journal, 5: 33-43.

ISPM 2. 2019. Framework for pest risk analysis. Rome, IPPC Secretariat, FAO.

ISPM 5. Glossary of phytosanitary terms. Rome, IPPC Secretariat, FAO.

ISPM 6. 2018. Surveillance. Rome, IPPC Secretariat, FAO.

ISPM 11. 2019. Pest risk analysis for quarantine pests. Rome, IPPC Secretariat, FAO.

ISPM 20. 2019. Guidelines for a phytosanitary import regulatory system. Rome, IPPC Secretariat, FAO.

ISPM 21. 2019. Pest risk analysis for regulated non-quarantine pests. Rome, IPPC Secretariat, FAO.

Jabran, K., Florentine, S. \& Chauhan, B.S. 2020. Impacts of climate change on weeds, insect pests, plant diseases and crop yields: Synthesis. In K. Jabran, S. Florentine \& B.S. Chauhan, eds. Crop protection under changing climate, pp. 189-196. Springer International Publishing.

Jactel, H., Desprez-Loustau, M.L., Battisti, A., Brockerhoff, E., Santini, A., Stenlid, A., Björkman, C. etal. 2020. Pathologists and entomologists must join forces against forest pest and pathogen invasions. NeoBiota, 58: $107-127$.

Jactel, H, Koricheva, J. \& Castagneyrol, B. 2019. Responses of forest insect pests to climate change: Not so simple. Current Opinion in Insect Science, 35: 103-108.

Janse, J.D. \& Obradovic, A. 2010. Xylella fastidiosa: Its biology, diagnosis, control and risks. Journal of Plant Pathology, 92: 35-48.

Jeger, M., Bragard, C., Caffier, D., Candresse, T., Chatzivassiliou, E., Dehnen-Schmutz, K., Gilioli, G. etal. 2018. Pest risk assessment of Spodoptera frugiperda for the European Union. EFSA Journal, 16(8): 5351 [online]. [Cited 6 April 2021]. https://doi.org/10.2903/j.efsa.2018.5351

Jeger, M.J. \& Pautasso, M. 2008. Plant disease and global change - the importance of long-term data sets. New Phytologist, 177: 8-11. 
Jones, J.T., Haegeman, A., Danchin, E.G.J., Gaur, H.S., Helder, J., Jones, M.G.K., Kikuchi, T. etal. 2013. Top 10 plantparasitic nematodes in molecular plant pathology. Molecular Plant Pathology, 14: 946-961.

Jones, R.A.C. 2016. Future scenarios for plant virus pathogens as climate change progresses. Advances in Virus Research, 95: 87-147.

Jönsson, A.M., Harding, S., Krokene, P., Lange, H., Lindelöw, Å., Økland, B. \& Ravn, H.P. \& Schroeder, M. 2011. Modelling the potential impact of global warming on Ips typographus voltinism and reproductive diapause. Climatic Change, 109: 606-718.

Junk, J., Jonas, M. \& Eickermann, M. 2016. Assessing meteorological key factors influencing crop invasion by pollen beetle (Meligethes aeneus F.) - past observations and future perspectives. Meteorologische Zeitschrift, 25: 357-364.

Juroszek, P., Racca, P., Link, S., Farhumand, J. \& Kleinhenz, B. 2020. Overview on the review articles published during the past 30 years relating to the potential climate change effects on plant pathogens and crop disease risks. Plant Pathology, 69: 179-193.

Juroszek, P. \& von Tiedemann, A. 2011. Potential strategies and future requirements for plant disease management under a changing climate. Plant Pathology, 60: 100-112.

Juroszek, P. \& von Tiedemann, A. 2013a. Plant pathogens, insect pests and weeds in a changing global climate: A review of approaches, challenges, research gaps, key studies and concepts. The Journal of Agricultural Science, 151: $163-188$.

Juroszek, P. \& von Tiedemann, A. 2013b. Climate change and potential future risks through wheat diseases. European Journal of Plant Pathology, 136: 21-33.

Juroszek, P. \& von Tiedemann, A. 2013c. Climatic changes and the potential future importance of maize diseases: A short review. Journal of Plant Diseases and Protection, 120: 49-56.

Juroszek, P. \& von Tiedemann, A. 2015. Linking plant disease models to climate change scenarios to project future risks of crop diseases: A review. Journal of Plant Diseases and Protection, 122: 3-15.

Karaca, M. \& Dursun, S.S. 2020. Possible effects of climate change on weeds in agriculture. Selcuk Journal of Agriculture and Food Sciences, 34: 111-117.

Karkanis, A., Ntatsi, G., Alemardan, A, Petropoulos, S. \& Bilalis, D. 2018. Interference of weeds in vegetable crop cultivation, in the changing climate of Southern Europe with emphasis on drought and elevated temperatures: A review. The Journal of Agricultural Science, 156: 1175-1185.

Kellermann, V. \& van Heerwaarden, B. 2019. Terrestrial insects and climate change: Adaptive responses in key traits. Physiological Entomology, 44: 99-115.

Kimathi, E., Tonnang, H.E.Z., Subramanian, S., Cressman, K., Abdel-Rahman, E.M., Tesfayohannes, M., Niassy, S., Torto, B. etal. 2020. Prediction of breeding regions for the desert locust Schistocerca gregaria in East Africa. Scientific Reports 10: 11937 [online]. [Cited 28 December 2020]. https://doi.org/10.1038/s41598-020-68895-2

King, M., Altdorff, D., Li, P. Galagedara L., Holden, J. \& Unc, A. 2018. Northward shift of the agricultural climate zone under 21st-century global climate change. Scientific Reports, 8: 7904 [online]. [Cited 31 March 2021]. https://doi.org/10.1038/s41598-018-26321-8

Kocmánková, E., Trnka, M., Eitzinger, J., Dubrovský, M., Štěpánek , P., Semerádová, D., Balek, J. etal. 2011. Estimating the impact of climate change on the occurrence of selected pests at high spatial resolution: A novel approach. The Journal of Agricultural Science, 149: 185-195.

Koo, T.H., Hong, S.J. \& Yun, S.C. 2016. Changes in the aggressiveness and fecundity of hot pepper anthracnose pathogen (Colletotrichum acutatum) under elevated $\mathrm{CO}_{2}$ and temperature over 100 infection cycles. The Plant Pathology Journal, 32: 260-265. 
Koricheva, J. \& Larsson, S. 1998. Insect performance on experimentally stressed woody plants: A meta-analysis. Annual Review Entomology, 43: 195-216.

Korres, N.E., Norsworthy, J.K., Tehranchian, P., Gitsopoulos, T.K., Loka, D.A., Oosterhuis, D.M., Gealy, D.R. etal. 2016. Cultivars to face climate change effects on crops and weeds: A review. Agronomy for Sustainable Development, 36: 12 [online]. [Cited 28 December 2020]. https://doi.org/10.1007/s13593-016-0350-5

Kremer, P., Schlüter, J., Racca, P., Fuchs, H.J. \& Lang, C. 2016. Possible impact of climate change on the occurrence and the epidemic development of cercospora leaf spot disease (Cercospora beticola sacc.) in sugar beets for RhinelandPalatinate and the southern part of Hesse. Climatic Change, 137: 481-494.

Kriticos, D.J., Watt, M.S., Potter, K.J.B., Mannig, L.K., Alexander, N.S. \& Tallent-Halsell, N. 2011. Managing invasive weeds under climate change: Considering the current and potential future distribution of Buddleja davidii. Weed Research, 51: 85-96.

Kumar, N. \& Khurana, S.M.P. 2020. Invasion of major fungal diseases in crop plants and forest trees due to recent climate fluctuations. In A. Raj, M.K. Jhariya, D.K. Yadav \&A. Banerjee, eds. Climate Change and Agroforestry Systems: Adaptation and Mitigation Strategies, Chapter 8, pp. 209-236. Burlington, Canada, Apple Academic Press.

Launay, M., Caubel, J., Bourgeois, G., Huard, F., de Cortazar-Atauri, I.G., Bancal, M.O. \& Brisson, N. 2014. Climatic indicators for crop infection risk: Application to climate impacts on five major foliar fungal diseases in Northern France. Agriculture, Ecosystems \& Environment, 197: 147-158.

Launay, M., Zurfluh, O., Huard, F., Buis, F., Bourgeois, G., Caubel, J., Huber, L. \& Bancal, M.O. 2020. Robustness of crop disease response to climate change signal under modelling uncertainties. Agricultural Systems, 178: 102733.

Leguizamon, E.S. \& Acciaresi, H.A. 2014. Climate change and the potential spread of Sorghum halepense in the central area of Argentina based on growth, biomass allocation and eco-physiological traits. Theoretical and Experimental Plant Physiology, 26: 101-113.

Lehmann, P., Ammunet, T., Barton, M., Battisti, A., Eigenbrode, S.D., Jepsen, J.U., Kalinkat, G. etal. 2020. Complex responses of global insect pests to climate warming. Frontiers in Ecology and the Environment, 18: 141-150.

Liang, L. \& Fei, S. 2014. Divergence of the potential invasion range of emerald ash borer and its host distribution in North America under climate change. Climatic Change, 122: 735-746.

Liebhold, A.M. \& Kean, J.M. 2019. Eradication and containment of non-native forest insects: Successes and failures. Journal of Pest Science, 92: 83-91.

Lipper, L., Thornton, P., Campbell, B.M., Baedeker, T., Braimoh, A., Bwalya, M., Caron, P., Cattaneo, A., Garrity, D. \& Henry, K. 2014. Climate-smart agriculture for food security. Nature Climate Change, 4: 1068-1072.

Litkas, V.D., Migeon, A., Navajas, M., Tixier, M.S. \& Stavrinides, M.C. 2019. Impacts of climate change on tomato, a notorious pest and its natural enemy: Small scale agriculture at higher risk. Environmental Research Letters, 14: 084041 [online]. [Cited 28 December 2020]. https://doi.org/10.1088/1748-9326/ab3313

Liu, T., Wan, A., Liu, D. \& Chen, X. 2017. Changes of races and virulence genes in Puccinia striiformis f. sp. tritici, the wheat stripe rust pathogen, in the United States from 1968 to 2009. Plant Disease, 101: 1522-1532.

Lopian, R. 2018. Climate change, sanitary and phytosanitary measures and agricultural trade. The state of agricultural commodity markets (SOCO) 2018: Background paper. Rome, FAO. 48 pp. (also available at http://www.fao.org/3/ CA2351EN/ca2351en.pdf).

Loustau, D., Ogee J., Dufrene, E., Deque, M., Duponey, J.I., Badeau, V., Viovy, N. etal. 2007. Impacts of climate change on temperate forests and interaction with management. In P.H. Freer-Smith, M.S.J. Broadmeadow \& J.M. Lynch, eds. Forestry and climate change, pp. 243-250. Wallingford, UK, CABI. 
Luck, I., Spackman, M., Freeman, A., Trebicki, P., Griffiths, W., Finlay, K. \& Chakraborty, S. 2011. Climate change and diseases of food crops. Plant Pathology, 60: 113-121.

Luo, Y., TeBeest, D.O., Teng, P.S. \& Fabellar, N.G. 1995. Simulation studies on risk analysis of rice blast epidemics associated with global climate change in several Asian countries. Journal of Biogeography, 22: 673-678.

Luo, Y., Teng, P.S., Fabellar, N.G. \& TeBeest, D.O. 1998. The effects of global temperature change on rice leaf blast epidemics: a simulation study in three agroecological zones. Agriculture, Ecosystems \& Environment, 68: 187-196.

Macfayden, S, McDonald, G. \& Hill, M.P. 2018. From species distributions to climate change adaptation: Knowledge gaps in managing invertebrate pests in broad-acre grain crops. Agriculture, Ecosystems \& Environment, 253: 208-219.

Maclean, I.M.D. 2020. Predicting future climate at high spatial and temporal resolution. Global Change Biology, 26(2): 1003-1011.

Madgwick, J.W., West, J.S., White, R.P., Semenov, M.A., Townsend, J.A., Turner, J.A. \& Fitt, B.D.L. 2011. Impacts of climate change on wheat anthesis and fusarium ear blight in the UK. European Journal of Plant Pathology, 130: $117-131$.

Magan, N., Medina, A. \& Aldred, D. 2011. Possible climate-change effects on mycotoxin contamination of food crops preand postharvest. Plant Pathology, 60: 150-163.

McConnachie, A.J., Strathie, L.W., Mersie, W., Gebrehiwot, L., Zewdie, K., Abdurehim, A., Abrha, B., Araya, T., Asaregew, F., Assefa, F., Gebre-Tsadik, R., Nigatu, L., Tadesse, B. \& Tana, T. 2011. Current and potential geographical distribution of the invasive plant Parthenium hysterophorus (Asteraceae) in eastern and southern Africa. Weed Research, 51: 71-84.

Manisankar, G. \& Ramesh, T. 2019. Response of weeds under elevated $\mathrm{CO}_{2}$ and temperature: A review. Journal of Pharmacognosy and Phytochemistry, SP2: 427-431.

Marshall, K.E., Gotthard, K. \& Williams, C.M. 2020. Evolutionary impacts of winter climate change on insects. Current Opinion in Insect Science, 41: 54-62.

Massad, T.J. \& Dyer, L.A. 2010. A meta-analysis of the effects of global environmental change on plant-herbivore interactions. Arthropod-Plant Interactions, 4: 181-188.

Matzrafi, M., Seiwert, B., Reemtsma, T., Rubin, B. \& Peleg, Z. 2016. Climate change increases the risk of herbicide-resistant weeds due to enhanced detoxification. Planta, 244: 1217-1227.

McCullough, D.G., Work, T.T., Cavey, J.F., Liebhold, A.M. \& Marshall, D. 2006. Interceptions of nonindigenous plant pests at US ports of entry and border crossings over a 17-year period. Biological Invasions, 8: 611-630.

Medina, A., Akbar, A., Baazeem, A., Rodriguez, A. \& Managan, N. 2017. Climate change, food security and mycotoxins. Do we know enough? Fungal Biology Reviews, 31(3): 143-154.

Mehmood, M.Z., Afzal, O., Aslam, M.A., Riaz, H., Raza, M.A., Ahmed, S., Qadir, G. etal. 2020. Disease modeling as a tool to assess the impacts of climate variability on plant diseases and health. In M. Ahmed, ed. Systems modeling, pp. 327-351. Singapore, Springer Nature Singapore.

Melloy, P., Hollaway, G., Luck, J., Norton, R., Aitken, E. \& Chakraborty, S. 2010. Production and fitness of Fusarium pseudograminearum inoculum at elevated carbon dioxide in FACE. Global Change Biology, 16: 3363-3373.

Meurisse, N., Rassati, D., Hurley, B.P., Brockerhoff, E.G. \& Haack, R.A. 2019. Common pathways by which non-native forest insects move internationally and domestically. Journal of Pest Science, 92: 13-27.

Meynard, C.N., Gay, P.E., Lecoq, M., Foucart, A., Piou, C. \& Chapuis, M.P. 2017. Climate-driven geographic distribution of the desert locust during recession periods: Subspecies' niche differentiation and relative risks under scenarios of climate change. Global Change Biology, 23: 4739-4749. 
Miedaner, T. \& Juroszek, P. 2021a. Climate change will influence disease resistance breeding in wheat in Northwestern Europe. Theoretical and Applied Genetics [online]. [Cited 13 March 2021]. https://doi.org/10.1007/s00122-021-03807-0

Miedaner, T. \& Juroszek, P. 2021b. Global warming and increasing maize cultivation demand comprehensive efforts in disease and insect resistance breeding in north-western Europe. Plant Pathology [online]. [Cited 26 February 2021]. https://doi.org/10.1111/ppa.13365

Mikkelsen, B.L., Jørgensen, R.B. \& Lyngkjær, M.F. 2014. Complex interplay of future climate levels of $\mathrm{CO}_{2}$, Ozone and temperature on susceptibility to fungal diseases in barley. Plant Pathology, 64: 319-327.

Misra, A.K., Yadav, S.B., Mishra, S.K. \& Tripathi, M.K. 2020. Impact of meteorological variables and climate change on plant diseases. In P. Kumar, A.K. Tiwari, M. Kamle, Z. Abbas \& P. Singh, eds. Plant pathogens - detection and management for sustainable agriculture, pp. 313-327. Oakville, Ontario, Canada, Apple Academic Press.

Moriyama, M. \& Numata, H. 2019. Ecophysiological responses to climate change in cicadas. Physiological Entomology, 44: 65-76.

Mostert, D., Molina, A.B., Daniells, J., Fourie, G., Hermanto, C., Chao, C.P., Fabregar, E. etal. 2017. The distribution and host range of the banana Fusarium wilt fungus Fusarium oxysporum f. sp. cubense, in Asia. PLoS ONE, 12: e0181630 [online]. [Cited 28 December 2020]. https://doi.org/10.1371/journal.pone.0181630

Munkvold, G.P. 2009. Seed pathology progress in the academia and industry. Annual Review of Phytopathology, 47: $285-311$.

Munkvold, G.P. \& Gullino, M.L. 2020. Seed and propagative material. In M.L. Gullino, R. Albajes \& P.C. Nicot, eds. Integrated pest and disease management in greenhouse crops, pp. 331-354. Dordrecht, The Netherlands, Springer Nature.

Naidu, V.S.G.R. 2015. Climate change, crop-weed balance and the future of weed management. Indian Journal of Weed Science, 47: 288-295.

Niblack, T.L. 2005 Soybean cyst nematode management reconsidered. Plant Disease, 89: 1020-1026.

O’Bannon, J.H. \& Tomerlin, A.T. 1973. Citrus tree decline caused by Pratylenchus coffeae. Journal of Nematology, 5: 311-316.

Oliveira, H., Stolf-Moreira, R., Martinez, C., Grillo, R., Jesus, M. \& Fraceto, L. 2015. Nanoencapsulation enhances the post-emergence herbicidal activity of atrazine against mustard plants. PLOS ONE, 10(7): e0132971 [online]. [Cited 28 December 2020]. https://doi.org/10.1371/journal.pone.0132971

Ormsby, M. \& Brenton-Rule, E. 2017. A review of global instruments to combat invasive alien species in forestry. Biological Invasions, 19: 3355-3364.

Paini, D.R., Mwebaze, P., Kuhnert, P.M. \& Kriticos, D.J. 2018. Global establishment threat from a major forest pest via international shipping: Lymantria dispar. Scientific Reports, 8: 13723. [online] [Cited 12 December 2020]. https://doi.org/10.1038/s41598-018-31871-y

Palmer, G., Platts, P.J., Brereton, T., Chapman, J.W., Dytham, C., Fox, R., Pearce-Higgins, J.W., Roy, D.B., Hill, J.K. \& Thomas, C.D. 2017. Climate change, climatic variation and extreme biological responses. Philosophical Transactions of the Royal Society B, 372: 20160144.

Paraschivu, M., Cotuna, O., Paraschivu, M. \& Olaru, L. 2019. Effects of interaction between abiotic stress and pathogens in cereals in the context of climate change: An overview. Annals of the University of Craiova, XLIX: 413-424.

Paterson, R.R.M. \& Lima, N. 2019. Ecology and biotechnology of thermophilic fungi on crops under global warming. In S.M. Tiquia-Arashiro \& M. Grube, eds. Fungi in extreme environments: Ecological role and biotechnological significance, pp. 81-96. Springer International Publishing.

Pautasso, M. 2013. Responding to diseases caused by exotic tree pathogens. In P. Gonthier \& G. Nicolotti, eds. Infectious forest diseases, pp. 29-49. Wallingford, UK and Boston, USA, CABI. 
Pautasso, M., Doring, T.F., Garbelotto, M., Pellis, L. \& Jeger, M.J. 2012. Impacts of climate change on plant diseases opinions and trends. European Journal of Plant Pathology, 133: 295-313.

Pegg, K.G., Coates, L.M., O’Neill, W.T. \& Turner, D.W. 2019. The epidemiology of Fusarium wilt of banana. Frontiers in Plant Science, 10: 1395 [online]. [Cited 28 December 2020]. https://doi.org/10.3389/fpls.2019.01395

Pegg, G., Taylor, T., Entwistle, P., Guymer, G., Giblin, F. \& Carnegie, A. 2017. Impact of Austropuccinia psidii (myrtle rust) on Myrtaceae-rich wet sclerophyll forests in south east Queensland. PLoS ONE 12(11): e0188058 [online]. [Cited 28 December 2020]. https://doi.org/10.1371/journal.pone.0188058

Peng, H.X.X., Sivasithamparam, K. \& Turner, D.W.W. 1999. Chlamydospore germination and Fusarium wilt of banana plantlets in suppressive and conducive soils are affected by physical and chemical factors. Soil Biology and Biochemistry, 31: 1363-1374.

Perez, C., Nicklin, C., Dangles, O., Vanek, S., Sherwood, S., Halloy, S., Garrett, K.A. \& Forbes, G. 2010. Climate change in the high Andes: Implications and adaptation strategies for small-scale farmers. International Journal of Environmental, Cultural, Economic and Social Sustainability, 6: 71-88.

Perrone, G., Ferrara, M., Medina, A., Pascale, M. \& Magan, N. 2020. Toxigenic fungi and mycotoxins in a climate change scenario: Ecology, genomics, distribution, prediction and prevention of the risk. Microorganisms, 8: 1496 [online]. [Cited 29 December 2020]. https://doi.org/10.3390/microorganisms8101496

Peters, K., Breitsameter, L. \& Gerowitt, B. 2014. Impact of climate change on weeds in agriculture: A review. Agronomy for Sustainable Development, 38: 707-721.

Peterson, A.T, Menon, S. \& Li, X. 2010. Recent advances in the climate change biology literature: Describing the whole elephant. WIREs Climate Change, 1: 548-555.

Ploetz, R.C. 2005. Panama disease, an old nemesis rears its ugly head: Part 1 - The beginnings of the banana export trades. Plant Health Progress, 6(1) [online]. [Cited 29 December 2020]. https://doi.org/10.1094/PHP-2005-1221-01-RV

Ploetz, R.C. \& Pegg, K.G. 2000. Fungal diseases of root, corm and pseudostem. In D.R. Jones, ed. Diseases of banana abacá and enset, pp. 143-172. Wallingford, UK, CABI.

Porter, J.R., Challinor, A.J., Henriksen, C.B., Howden, S.M., Martre, P. \& Smith, P. 2019. IPCC, agriculture and food a case of shifting cultivation and history. Global Change Biology, 25(8): 2518-2529.

Prank, M., Kenaley, S.C., Bergstrom, G.C., Acevedo, M. \& Mahowald, N.M. 2019. Climate change impacts the spread of wheat stem rust, a significant crop disease. Environmental Research Letters, 14: 124053 [online]. [Cited 29 December 2020]. https://doi.org/10.1088/1748-9326/ab57de

Preisler, A.C., Pereira, A.E., Campos, E.V., Dalazen, G., Fraceto, L.F. \& Oliveira, H.C. 2020. Atrazine nanoencapsulation improves pre-emergence herbicidal activity against Bidens pilosa without enhancing long-term residual effect on Glycine max. Pest Management Science, 76(1): 141-149.

Pritchard, S.G. 2011. Soil organisms and global climate change. Plant Pathology, 60: 82-99.

Priyanka, A.K.M., Varma, S., Kumar, V. \& Sharma, R.S. 2020. Impact of climate change on plant diseases and management strategies: A review. International Journal of Chemical Studies, 8: 2968-2973.

Pugliese, M., Gullino, M.L. \& Garibaldi, A. 2010. Effects of elevated $\mathrm{CO}_{2}$ and temperature on interactions of grapevine and powdery mildew: First results under phytotron conditions. Journal of Plant Diseases and Protection, 117: 9-14.

Qin, Z., Zhang, J.E., Di Tommaso, A., Wang, R.I. \& Liang, K.M. 2016. Predicting the potential distribution of Lantana camara L. under RCP scenarios using ISI-MIP models. Climatic Change, 134: 193-208.

Racca, P., Kakau, J., Kleinhenz, B. \& Kuhn, C. 2015. Impact of climate change on the phenological development of winter wheat, sugar beet and winter oilseed rape in Lower Saxony, Germany. Journal of Plant Diseases and Protection, 122: 16-27. 
Raderschall, C.A., Vico, G., Lundin, O., Taylor, A.R. \& Bommarco, R. 2021. Water stress and insect herbivory interactively reduce crop yield while the insect pollination benefit is conserved. Global Change Biology, 27: 71-83.

Rai, M. \& Ingle, A. 2012. Role of nanotechnology in agriculture with special reference to management of insect pests. Applied Microbiology and Biotechnology, 94 (2): 287-293 [online]. [Cited 29 December 2020].

https://doi.org/10.1007/s00253-012-3969-4

Raliya, R., Saharan, V., Dimkpa, C. \& Biswas, P. 2018. Nanofertilizer for precision and sustainable agriculture: Current state and future perspectives. Journal of Agricultural and Food Chemistry, 66(26): 6487-6503.

Ramesh, K., Matloob, A., Aslam, F., Florentine, S.K. \& Chauhan, B.S. 2017. Weeds in a changing climate: Vulnerabilities, consequences, and implications for future weed management. Frontiers in Plant Science, 8: 95 [online]. [Cited 28 December 2020]. https://doi.org/10.3389/fpls.2017.00095

Ramirez-Cabral, N.Y.Z, Kumar, L. \& Shabani, F. 2017. Future climate scenarios project a decrease in the risk of fall armyworm outbreaks. The Journal of Agricultural Science, 155(8): 1219-1238.

Ramirez-Cabral, N.Y.Z., Kumar, L. \& Shabani, F. 2019. Suitable areas of Phakopsora pachyrhizi, Spodoptera exigua, and their host plant Phaseolus vulgaris are projected to reduce and shift due to climate change. Theoretical and Applied Climatology, 135: 409-424.

Ramsfield, T.D., Bentz, B.J., Faccoli, M., Jactel, H. \& Brockerhoff, E.G. 2016. Forest health in a changing world: Effects of globalization and climate change on forest insect and pathogen impacts. Forestry, 89: 245-252.

Rathee, M. \& Dalal, P. 2018. Emerging insect pests in Indian agriculture. Indian Journal of Entomology, 80: $267-281$.

Reineke, A. \& Thiéry, D. 2016. Grapevine insect pests and their natural enemies in the age of global warming. Journal of Pest Science, 89: 313-328.

Revich, B., Tokarevich, N. \& Parkinson, A.J. 2012. Climate change and zoonotic infections in the Russian Arctic. International Journal of Circumpolar Health, 71: 18792 [online]. [Cited 29 December 2020]. https://doi.org/10.3402/ijch.v71i0.18792

Reynaud, B., Delatte, H., Peterschmitt, M. \& Fargette, D. 2009. Effects of temperature increase on the epidemiology of three major vector-borne viruses. European Journal of Plant Pathology, 123: 269-280.

Richerzhagen, D., Racca, P., Zeuner, T., Kuhn, C., Falke, K., Kleinhenz, B. \& Hau, B. 2011. Impact of climate change on the temporal and regional occurrence of Cercospora leaf spot in Lower Saxony. Journal of Plant Diseases and Protection, 118: 168-177.

Rizzo, D., Garbelotto, M. \& Hansen, E. M. 2005. Phythophora ramorum: Integrative research and management of an emerging pathogen in California and Oregon forests. Annual Review of Phytopathology, 43: 309-335.

Robinet, C. \& Roques, A. 2010. Direct impacts of recent climate warming on insect populations. Integrative Zoology, 5: 132-142.

Roth, M.G., Webster, R.W., Mueller, D.S., Chilvers, M.I., Faske, T.R., Mathew, F.M., Bradley, C.A., Damicone, J.P., Kabbage, M. \& Smith, D.L. 2020. Integrated management of important soybean pathogens of the United States in changing climate. Journal of Integrated Pest Management, 11: 17 [online]. [Cited 29 December 2020]. https://doi.org/10.1093/jipm/pmaa013

Ruttledge, A. \& Chauhan, B.S. 2020. Climate change and weeds of cropping systems. In K. Jabran, S. Florentine \& B.S. Chauhan, eds. Crop protection under changing climate, pp. 57-84. Springer International Publishing.

Sabry, K. \& Ragaei, M. 2018. Nanotechnology and their applications in insect's pest control. In K.A. Abd-Elsalam \& R. Prasad, eds. Nanobiotechnology applications in plant protection, pp. 1-28. Cham, Springer International Publishing AG. https://doi.org/10.1007/978-3-319-91161-8.

Salinari, F., Giosuè, S., Rettori, A., Rossi, V., Tubiello, F.N., Spanna, F., Rosenzweig, C. \& Gullino, M.L. 2006. Downy mildew (Plasmopara viticola) epidemics on grapevine under climate change. Global Change Biology, 12: 1299-1307. 
Salinari, F., Giosuè, S., Rossi, V., Tubiello, F.N., Rosenzweig, C. \& Gullino, M.L. 2007. Downy mildew outbreaks on grapevine under climate change: Elaboration and application of an empirical-statistical model. EPPO Bulletin, 37 : 317-326.

Salvacion, A.R., Cumagun, C.J.R., Pangga, I.B., Magcale-Macandog D.B., Cruz, P.C.S., Saludes, R.B., Solpot, T.C. \& Aguilar, E.A. 2019. Banana suitability and Fusarium wilt distribution in the Philippines under climate change. Spatial Information Research, 27: 339-349.

Santini, A. \& Battisti, A. 2019. Complex insect-pathogen interactions in tree pandemics. Frontiers in Physiology, 10: 550 [online]. [Cited 29 December 2020]. https://doi.org/10.3389/fphys.2019.00550

Saponari, M., Boscia, D., Nigro, F. \& Martelli, G.P. 2013. Identification of DNA sequences related to Xylella fastidiosa in oleander, almond and olive trees exhibiting leaf scorch symptoms in Apulia (Southern Italy). Journal of Plant Pathology, 95(3): 668.

Saunders, D.G.O., Pretorius, Z.A. \& Hovmøller, M.S. 2019. Tackling the re-emergence of wheat stem rust in Western Europe. Communications Biology, 2: 51 [online]. [Cited 29 December 2020]. https://doi.org/10.1038/s42003-019-0294-9

Savary, S., Willocquet, L., Pethybridge, S.J., Esker, P., McRoberts, N. \& Nelson, A. 2019. The global burden of pathogens and pests on major food crops. Nature Ecology \& Evolution, 3: 430-439. Scalone, R., Lemke, A., Stefanic, E., Kolseth, A.K., Rasic, S. \& Andersson, L. 2016. Phenological variation in Ambrosia artemisiifolia L. facilitates near future establishment at northern latitudes. PLOS ONE, 11: e0166510 [online]. [Cited 31 March 2021].

https://doi.org/10.1371/journal.pone.0166510

Scheffers, B.R., De Meester, L., Bridge, T.C.L., Hoffmann, A.A., Pandolfi, J.M., Corlett, R.T., Butchart, S.H.M. etal. 2016. The broad footprint of climate change from genes to biomes to people. Science, 354 (6313): aaf7671.

Schneider, K., van der Werf, W., Cendoya, M., Mourits, M., Navas-Cortes J.A., Vicent, A. \& Lansink, A.O. 2020. Impact of Xylella fastidiosa subspecies pauca in European olives. PNAS, 117: 9250-9259.

Schumann, G.L. 1991. Plant diseases: Their biology and social impact. St Paul, USA, APS Press.

Scott, N.R., Chen, H. \& Cui, H. 2018. Nanotechnology applications and implications of agrochemicals toward sustainable agriculture and food systems. Journal of Agricultural and Food Chemistry, 66(26): 6451-6456.

Scott, P. \& Williams, N. 2014. Phytophthora diseases in New Zealand forests. New Zealand Journal of Forestry, 59: 14-21.

Seidl, R., Thom, D., Kautz, M., Martin-Benito, D., Peltoniemi, M., Vacchiano G., Wild, J. etal. 2017. Forest disturbances under climate change. Nature Climate Change, 7: 395-402.

Shabani, F., Ahmadi, M., Kumar, L., Soljouy-Fad, S., Tehrany, M.S., Shabani, F., Kalantar, B. \& Esmaeili, A. 2020. Invasive weed species' threats to global biodiversity: Future scenarios of changes in the number of invasive species in a changing climate. Ecological Indicators, 116: 106436 [online]. [Cited 29 December 2020].

https://doi.org/10.1016/j.ecolind.2020.106436

Shabani, F. \& Kumar, L. 2013. Risk levels of invasive Fusarium oxysporum f. sp. in areas suitable for date palm (Phoenix dactylifera) cultivation under various climate change projections. PLOS ONE, 8: e83404 [online]. [Cited 29 December 2020]. https://doi.org/10.1371/journal.pone.0083404

Shaibu, A.S., Li, B., Zhang, S. \& Sun, J. 2020. Soybean cyst nematode-resistance: Gene identification and breeding strategies. The Crop Journal, 8(6): 892-904 [online]. [Cited 29 December 2020]. https://doi.org/10.1016/j.cj.2020.03.001

Sharma, S., Hooda, K.S. \& Goswami, P. 2019. Scenario of plant diseases under changing climate. Journal of Pharmacognosy and Phytochemistry, 8: 2490-2495.

Shaw, M.W. \& Osborne, T.M. 2011. Geographic distribution of plant pathogens in response to climate change. Plant Pathology, 60: 31-43. 
Sicard, A., Zeilinger, A.R., Vanhove, M., Schartel, T.E., Beal, D.J., Daugherty, M.P. \& Almeida, R.P.P. 2018. Xylella fastidiosa: Insights into an emerging plant pathogen. Annual Review of Phytopathology, 56: 181-202.

Siciliano, I., Berta, F., Bosio, P., Gullino, M.L. \& Garibaldi, A. 2017a. Effect of different temperatures and $\mathrm{CO}_{2}$ levels on Alternaria toxins produced on cultivated rocket, cabbage and cauliflower. World Mycotoxin Journal, 10: 63-71.

Siciliano, I., Bosio, P., Gilardi, G., Gullino, M.L. \& Garibaldi, A. 2017b. Verrucarin A and roridin E produced on spinach by Myrothecium verrucaria under different temperatures and $\mathrm{CO}_{2}$ levels. Mycotoxin Research, 33: 139-146.

Sidorova, I. \& Voronina, E. 2020. Terrestrial fungi and global climate change. In J. Marxsen, ed. Climate change and microbial ecology: Current research and future trends, 2nd edn, Chapter 5. Poole, UK, Caister Academic Press. (also available at https://doi.org/10.21775/9781913652579.05).

Singh, V.K., Shukla, A.K. \& Singh, A.K. 2019. Impact of climate change on plant-microbe interactions under agroecosystems. In K.K. Choudhary, A. Kumar \& A.K. Singh, eds. Climate change and agricultural ecosystems, pp. 153-179. Cambridge, UK, Woodhead Publishing, Elsevier.

Skelsey, P., Cooke, D.E.L., Lynott, J.S. \& Lees, A.K. 2016. Crop connectivity under climate change: Future environmental and geographic risks of potato late blight in Scotland. Global Change Biology, 22: 3724-3738.

Sousa, E., Naves, P., Bonifácio, L., Henriques, J., Inácio, M.L. \& Evans, H. 2011. Survival of Bursaphelenchus xylophilus and Monochamus galloprovincialis in pine branches and wood packaging material. EPPO Bulletin, 41: 203-207.

Sparks, A.H., Forbes, G.A., Hijmans, R.J. \& Garrett, K.A. 2014. Climate change may have limited effect on global risk of potato late blight. Global Change Biology, 20: 3621-3631.

Srivastava, A., Kumar, S.N. \& Aggarwal, P.K. 2010. Assessment of vulnerability of sorghum to climate change in India. Agriculture, Ecosystems \& Environment, 138: 160-169.

Stack, J., Fletcher, J. \& Gullino, M.L. 2013. Climate change and plant biosecurity: A new world disorder? In B. Bodo, C. Burnley, I. Comardicea, A. Maas \& R. Roffey, eds. Global environmental change: New drivers for resistance, crime and terrorism, pp. 161-181. Baden-Baden, Germany, Nomos.

STDF/World Bank. 2011. Climate change and trade: The link to sanitary and phytosanitary standards. Joint paper of the World Bank, Development Research Group, Trade and International Integration (DECTI) and the Standards and Trade Development Facility (STDF). Geneva, 26 pp. (also available at https://www.standardsfacility.org/sites/default/files/ STDF_Climate_Change_EN_0.pdf).

St-Marseille, A.F.G., Bourgeois, G., Brodeur, J. \& Mimee, B. 2019. Simulating the impacts of climate change on soybean cyst nematode and the distribution of soybean. Agricultural and Forest Meteorology, 264: 178-187.

Stoeckli, S., Felber, R. \& Haye, T. 2020. Current distribution and voltinism of the brown marmorated stink bug, Halyomorpha halys, in Switzerland and its response to climate change using a high-resolution CLIMEX model. International Journal of Biometeorology, 64: 2019-2032 [online]. [Cited 29 December 2020]. https://doi.org/10.1007/s00484-020-01992-z

Storkey, J., Stratonovitch, P., Chapman, D. \& Vidotto, F. 2014. A process-based approach to predicting the effect of climate change on the distribution of an invasive allergenic plant in Europe. PLOS ONE, 9: e88156 [online]. [Cited 29 December 2020]. https://doi.org/10.1371/journal.pone.0088156

Stover, R.H. 1986. Disease management strategies and the survival of the banana industry. Annual Review of Phytopathology, 24: 83-91.

Strand, J.F. 2000. Some agrometeorological aspects of pest and disease management for the 21st century. Agricultural and Forest Meteorology, 103: 73-82.

Sturrock, R.N., Frankel, S.J., Brown, A.V., Hennon, P.E., Kliejunas, J.T. \& Lewis, K.J. 2011. Climate change and forest diseases. Plant Pathology, 60: 133-149. 
Su, C., Ji, Y., Gao, S., Cao, S., Xu, X., Zhou, C. \& Liu, Y. 2020. Fluorescence-labeled abamectin nanopesticideforcomprehensive control of pinewood nematode and Monochamus alternatus hope. ACS Sustainable Chemistry \& Engineering, 8(44): 16555-16564 [online]. [Cited 29 December 2020]. https://doi.org/10.1021/acssuschemeng.0c05771

Suggitt, A.J., Wilson, R.J., Isaac, N.J., Beale, C.M., Auffret, A.G., August, T., Maclean, I.M.D. etal. 2018. Extinction risk from climate change is reduced by microclimatic buffering. Nature Climate Change, 8(8): 713-717.

Sun, Y., Ding, J., Siemann, E. \& Keller, S.R. 2020. Biocontrol of invasive weeds under climate change: Progress, challenges and management implications. Current Opinion in Insect Science, 38: 72-78.

Sutherst, R.W. 1991. Pest risk analysis and the greenhouse effect. Review of Agricultural Entomology, 79: 1177-1187.

Sutherst, R.W., Baker, R.H.A., Coakley, S.M., Harrington, R., Kriticos, D.J. \& Scherm, H. 2007. Pest under global change - meeting your future landlords? In J.G. Canadell, D.E. Pataki \& L.F. Pitelka, eds. Terrestrial ecosystems in a changing world. Berlin, Springer, pp. 211-226.

Sutherst, R.W., Constable, F., Finlay, K.J., Harrington, R., Luck, J. \& Zalucki, M.P. 2011. Adapting to crop pest and pathogen risks under a changing climate. WIREs Climate Change, 2: 220-237.

Sutherst, R.W., Maywald, G.F. \& Russell, B.L. 2000. Estimating vulnerability under global change: Modular modelling of pests. Agriculture, Ecosystems \& Environment, 82(1-3): 303-319.

Taylor, R.A.J., Herms, D.A., Cardina, J. \& Moore, R.H. 2018. Climate change and pest management: Unanticipated consequences of trophic dislocation. Agronomy, 8(1): 7 [online]. [Cited 29 December 2020]. https://doi.org/10.3390/agronomy8010007

Tenllado, F. \& Canto, T. 2020. Effects of a changing environment on the defences of plants to viruses. Current Opinion in Virology, 42: 40-46.

Thomas J.E., Wood, T.A., Gullino, M.L. \& Ortu, G. 2017. Diagnostic tools for plant biosecurity. In M.L. Gullino, J. Stack, J. Fletcher \& J. Mumford, eds. Practical tools for plant and food biosecurity, pp. 209-226. Dordrecht, The Netherlands, Springer.

Thomas-Sharma, S., Abdurahman, A., Ali, S., Andrade-Piedra, J., Bao, S., Charkowski, A., Crook, D. etal. 2016. Seed degeneration in potato: The need for an integrated seed health strategy to mitigate the problem in developing countries. Plant Pathology, 65: 3-16.

Thomson, L.J., MacFadyen, S. \& Hoffmann, A.A. 2010. Predicting the effects of climate change on natural enemies of agricultural pests. Biological Control, 52: 296-306.

Torney, F., Trewyn, B.G., Lin, V.S.-Y. \& Wang, K. 2007. Mesoporous silica nanoparticles deliver DNA and chemicals into plants. Nature Nanotechnology, 2(5): 295-300.

Torresen, K.S., Fykse, H., Rafoss, T. \& Gerowitt, B. 2020. Autumn growth of three perennial weeds at high latitude benefits from climate change. Global Change Biology, 26: 2561-2572.

Trebicki, P. 2020. Climate change and plant virus epidemiology. Virus Research, 286: 198059. https://doi.org/10.1016/j. virusres.2020.198059

Trebicki, P. \& Finlay, K. 2019. Pests and diseases under climate change; its threat to food security. In S.S. Yadav, R.J. Redden, J.L. Hatfield, A.W. Ebert \& D. Hunter, eds. Food security and climate change, pp. 229-249. New York, John Wiley \& Sons Inc.

Tresson, P., Brun, L., de Cortazar-Atauri, I.G., Audergon, J.M., Buléon, S., Chenevotot, H., Combe, F. etal. 2020. Future development of apricot blossom blight under climate change in Southern France. European Journal of Agronomy, 112: 125960 .

Tylka, G.L. \& Marett, C.C. 2014. Distribution of the soybean cyst nematode, Heterodera glycines, in the United States and Canada: 1954 to 2014. Plant Health Progress, 15: 85-87. 
Valerio, M., Tomecek, M.B., Lovelli, S. \& Ziska, L.H. 2011. Quantifying the effect of drought on carbon dioxide-induced changes in competition between a C3 crop and a C4 weed (Amaranthus retroflexus). Weed Research, 51: 591-600.

Van der Fels-Klerx, H.J., Liu, C. \& Battilani, P. 2016. Modelling climate change impacts on mycotoxin contamination. World Mycotoxin Journal, 9: 717-726.

Van der Putten, W.H., Macel, M. \& Visser, M.E. 2010. Predicting species distribution and abundance responses to climate change: Why it is essential to include biotic interactions across trophic levels. Philosophical Transactions of the Royal Society B: Biological Sciences, 365: 2025-2034.

Vilà, M., Beaury, E.M., Blumenthal, D.M., Bradley, B.A., Early, R., Laginhas, B.B., Trillo, A., Dukes, J.S., Sorte, C.J.B. \& Ibáñez, I. 2021. Understanding the combined impacts of weeds and climate change on crops. Environmental Research Letters, 16: 034043.

Viswanath, K., Sinha, P., Kumar, S.N., Sharma, T., Saxena, S., Panjwani, S., Pathak, H. \& Shukla, S.M. 2017. Simulation of leaf blast infection in tropical rice agro-ecology under climate change scenario. Climatic Change, 142: 155-167.

Wan, J.Z. \& Wang, C.J. 2019. Contribution of environmental factors toward distribution of ten most dangerous weed species globally. Applied Ecology and Environmental Research, 17: 14835-14846.

Wang, C., Hawthorne, D., Qin, Y., Pan, X., Li, Z. \& Zhu, S. 2017. Impact of climate and host availability on future distribution of Colorado potato beetle. Scientific Reports, 7: 4489 [online]. [Cited 29 December 2020].

https://doi.org/10.1038/s41598-017-04607-7

Wang, C., Zhang, X., Pan, X., Li, Z. \& Zhu, S. 2015. Greenhouses: Hotspots in the invasive network for alien species. Biodiversity and Conservation, 24: 1825-1829.

Wang, R., Li, Q., He, S., Liu, Y., Wang, M. \& Jiang, G. 2018. Modeling and mapping the current and future distribution of Pseudomonas syringae pv. actinidiae under climate change in China. PLoS ONE, 13: e0192153 [online]. [Cited 29 December 2020]. https://doi.org/10.1371/journal.pone.0192153

Watt, M.S., Kriticos, D.J., Lamoureaux, S.L. \& Bourdot, G.W. 2011. Climate change and the potential global distribution of serrated tussock (Nassella trichotoma). Weed Science, 59: 538-545.

Wattanapongsiri, A. 1966. A revision of the genera Rhynchophorus and Dynamis (Coleoptera: Curculionidae). Department of Agriculture Science Bulletin. Bangkok, Department of Agriculture Science.

Wells, J.M., Raju, B.C., Hung, H.Y., Weisburg, W.G., Mandelco-Paul, L. \& Brenner, D.J. 1987. Xylella fastidiosa gen. nov., sp. nov.: Gram-negative, xylem-limited, fastidious plant bacteria related to Xanthomonas spp. International Journal of Systematic Bacteriology, 37(2): 136-143.

West, A.M., Kumar, S., Wakie, T., Brown, C.S., Stohlgren, J., Laituri, M. \& Bromberg, J. 2015. Using high-resolution future climate scenarios to forecast Bromus tectorum invasion in Rocky Mountain National Park. PLoS ONE, 10: e0117893 [online]. [Cited 29 December 2020]. https://doi.org/10.1371/journal.pone.0117893

Wilkinson, K., Grant, W.P., Green, L.E., Hunter, S., Jeger, M.J., Lowe, P., Medley, G.F. etal. 2011. Infectious diseases of animals and plants: An interdisciplinary approach. Philosophical Transactions of the Royal Society B: Biological Sciences, 366: 1933-1942.

Williams, A.L., Wills, K.E., Janes, J.K., Van der Schoor, J.K., Newton, P.C.D. \& Hovenden, M.J. 2007. Warming and free-air $\mathrm{CO}_{2}$ enrichment alter demographics in four co-occurring grassland species. New Phytologist, 176: 365-374.

Williamson, V.M. \& Gleason, C.A. 2003. Plant-nematode interactions. Current Opinion in Plant Biology, 6: $327-333$.

Wolfe, D.W., Ziska, L., Petzoldt, C., Seaman, A., Chase, L. \& Hayhoe, K. 2008. Projected change in climate thresholds in the Northeastern U.S.: Implications for crops, pests, livestock, and farmers. Mitigation and Adaptation Strategies for Global Change, 13: 555-575. 
Woolhouse, M.E.J., Webster, J.P., Domingo, E., Charlesworth, B. \& Levin, B.R. 2002. Biological and biomedical implications of the co-evolution of pathogens and their hosts. Nature Genetics, 32 (4): 569-577.

Wright, D., Hammond, N., Thomas, G., MacLeod, B. \& Abbott, L.K. 2018. The provision of pest and disease information using Information Communication Tools (ICT); an Australian example. Crop Protection, 103: 20-29.

Wu, E., Wang, Y.-P., Yahuza, L., He, M.-H., Sun, D.-L., Huang, Y.-M., Liu, Y.-C., Yang, L.N., Zhu, W. \& Zhan, J. 2020. Rapid adaptation of the Irish potato famine pathogen Phytophthora infestans to changing temperature. Evolutionary Applications, 13(4): 768-780.

Wuebbles, D.J. \& Hayhoe, K. 2002. Atmospheric methane and global change. Earth-Science Reviews, 57: 177-210.

Yadav, S., Stow, A.J. \& Dudaniec, R. 2019. Detection of environmental and morphological adaptation despite high landscape genetic connectivity in a pest grasshopper (Phaulacridium vittatum). Molecular Ecology, 28: 3395-3412.

Zacarias, D.A. 2020. Global bioclimatic suitability for the fall armyworm, Spodoptera frugiperda (Lepidoptera: Noctuidae), and potential co-occurrence with major host crops under climate change scenarios. Climatic Change, 161: 555-566.

Zhao, X., Cui, H., Wang, Y., Sun, C., Cui, B. \& Zeng, Z. 2018. Development strategies and prospects of nano-based smart pesticide formulation. Journal of Agricultural and Food Chemistry, 66(26): 6504-651.

Ziska, L.H., Blumenthal, D.M. \& Franks, S.J. 2019. Understanding the nexus of rising $\mathrm{CO}_{2}$, climate change, and evolution in weed biology. Invasive Plant Science and Management, 12: 79-88.

Ziska, L.H., Epstein, P.R. \& Schlesinger, W.H. 2009. Rising $\mathrm{CO}_{2}$, climate change, and public health: Exploring the links to plant biology. Environmental Health Perspectives, 117: 155-158. 




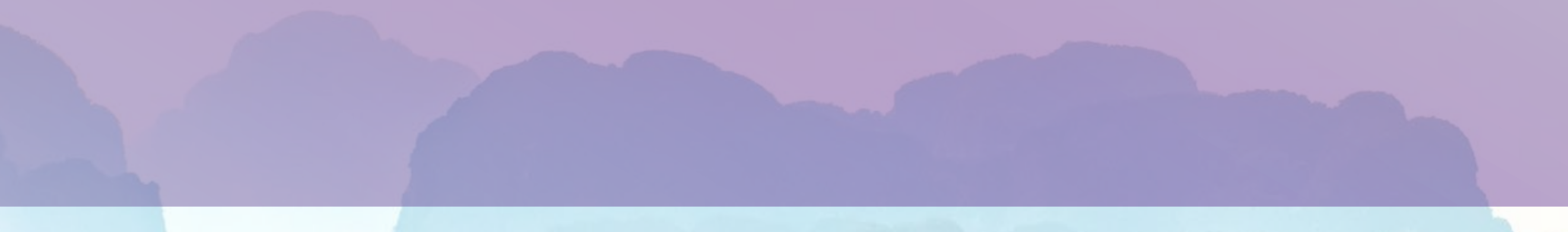




\section{IPPC}

The International Plant Protection Convention (IPPC) is an international plant health agreement that aims to protect global plant resources and facilitate safe trade.

The IPPC vision is that all countries have the capacity to implement harmonized measures to prevent pest introductions and spread, and minimize the impacts of pests on food security, trade, economic growth, and the environment.

\section{Organization}

- There are over 180 IPPC contracting parties.

- Each contracting party has a national plant protection organization (NPPO) and an Official IPPC contact point.

- 10 regional plant protection organizations (RPPOs) have been established to coordinate NPPOs in various regions of the world.

- The IPPC Secretariat liaises with relevant international organizations to help build regional and national capacities.

- The Secretariat is provided by the Food and Agriculture Organization of the United Nations (FAO).

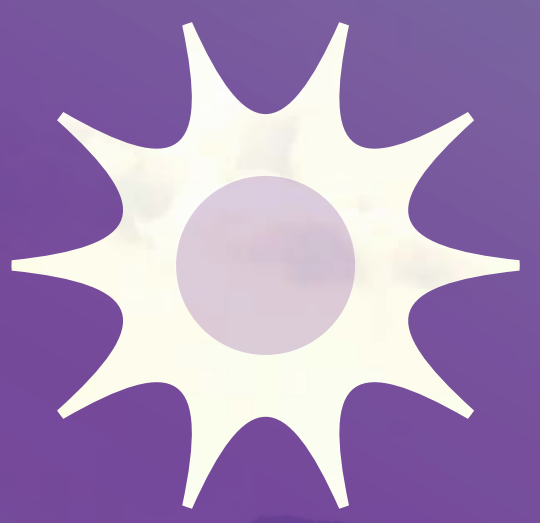

International Plant Protection Convention Secretariat ippc@fao.org|www.ippc.int

Food and Agriculture Organization of the United Nations Rome, Italy

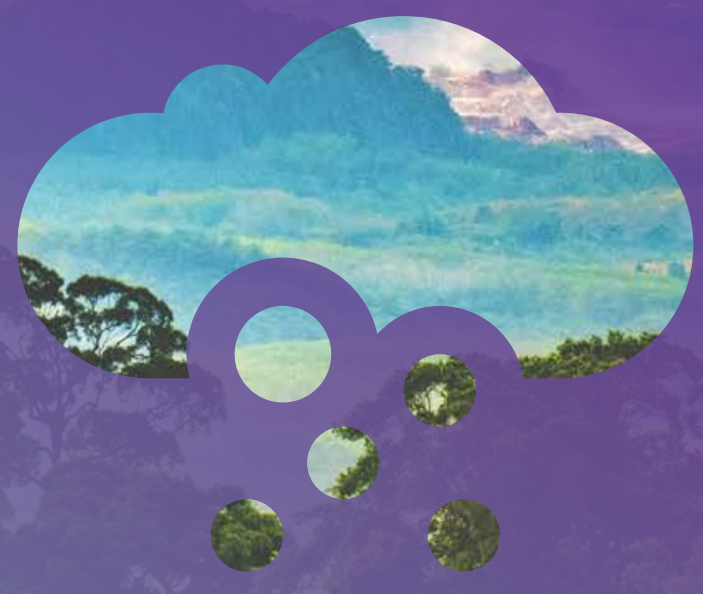

